\title{
AVALIAÇÃO DA QUALIDADE FÍSICA E FISIOLÓGICA DE SEMENTES DE AMENDOIM (Arachis hypogaea L.) SUBMETIDO A DIFERENTES FONTES DE CÁlCIO COMBINADAS A ÉPOCAS E MODOS DE APLICAÇÃO
}

\section{MARIA CRISTINA MINGUES SPINOLA \\ Engenheiro Agrônomo}

Orientador: Prof. Dr. Silvio Moure Cicero

\begin{abstract}
Dissertação apresentada à Escola Superior de Agricultura "Luiz de Queiroz",da Universidade de São Paulo, para obtenção de título de Mestre em Agronomia. Área de concentração : Fitotecnia.
\end{abstract}

P I R A C I C A B A

Estado de São Paulo - Brasil

Novembro - 1994 
Dados Internacionais de Catalogação na Publicação (CIP) DIVISÃo DE BIBLIOTECA E DOCUMENTAÇÃo - Campus "Luiz de Queiroz"/USP

Spinola, Maria Cristina Mingues

Avaliação da qualidade fisica e fisiológica de sementes de amendoim (Arachis hypogaea L.) submetido a diferentes fontes de cálcio combinadas a épocas e modos de aplicaçāo / Maria Cristina Mingues Spinola. - - Piracicaba, 1994.

$110 \mathrm{p}$.

Dissertaçāo (mestrado) - - Escola Superior de Agricultura Luiz de Queiroz, 1994. Bibliografia.

1. Amendoim 2. Cálcio 3. Semente (qualidade) I. Titulo 
AVALIAÇÃO DA QUALIDADE FÍSICA E FISIOLÓGICA DE SEMENTES DE AMENDOIM (Arachis hypogaea L.) SUBMETIDO A DIFERENTES FONTES DE CÁlCIO COMBINADAS A ÉPOCAS E MODOS DE APLICAÇÃO

Aprovada em: 02/07/95

Comissão julgadora:

Prof. Dr. Silvio Moure Cicero ESALQ/USP

Prof. Dr. Gil Miguel Câmara ESALQ/USP

Prof. Dr. Nelson Moreira de Carvalho FCAVJ/UNESP

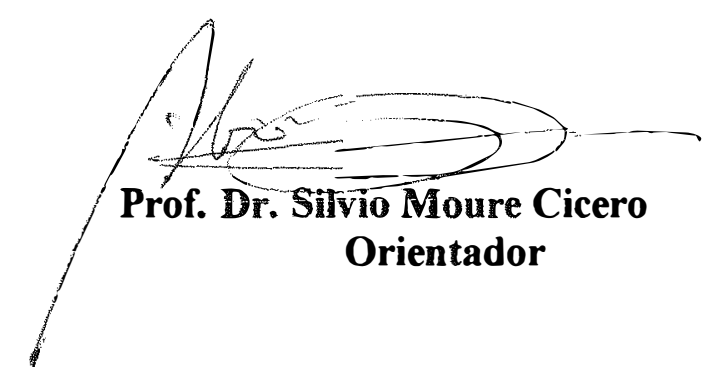


Aos meus pais Helena e Miguel que pelos seus eternos ensinamentos de vida demonstraram que todos somos passiveis de erros, mas que com amor tudo se supera. 


\section{Agradecimentos}

Ao Prof. Dr. Silvio Moure Cicero, pela orientação e constante apoio.

Aos Professores Dr. Gil Miguel Câmara e Dr. Nelson Moreira de Carvalho pelas valiosas sugestões e estímulos.

Aos Professores Dr. Francisco Ferraz de Toledo, Dr. Dr. Walter Rodrigues da Silva, pelos ensinamentos $\epsilon$ citerişcio sempre dispensada.

Às Engenheiras Agrônomos Helena M. C. P. Chamma e Ana Dionisia C. L. Novembre, pela amizade, orientação e constante apoio.

Aos estagiários do Departamento, em especial ao acadêmico Luiz Carlos Monobi e ao colega de curso Rodrigo Egea Miranda, pela colaboração na realização deste trabalho.

À Profa ${ }^{a}$ Dr. Maria Cristina Stolf Nogueira pela atenção e valiosa colaboração no planejamento da análise estatística.

Aos funcionários do Departamento de Agricultura, em especial a llze Helena de Gaspari das Neves, Hodair Banzatto, Carlos A. Carlet, João E. Jabur, João B. Bigelli, Celestino A. Ferreira e Maria Aparecida T. Soledade, pela colaboração e prezado convivio.

Às laboratoristas Lúcia Helena S.P. Forti, Nivanda M. Moura e Lurdes D. Gonzalvez pelo auxílio na execução das análises no Laboratório de Nutrição Mineral de Plantas. 
Ao Conselho Nacional de Pesquisa e Desenvolvimento Tecnológico (CNPq) pela bolsa de estudos concedida.

À Fundação de Amparo à Pesquisa do Estado de São Paulo (FAPESP) pelo suporte financeiro e bolsa concedida para a realização do projeto.

Aos colegas do curso de pós-graduação pela amizade, carinho e incentivos, em especial à Édila V. R. Von Pinho, Claudio Cavariani, Denise C.F. Dias, Monalisa A.Diniz da Silva, Ceci C. Castilho e Marco A. de Souza.

À família Martins em nome de: Marise, Mônica, Mauricio, Márcio, Sr.Edmilson e Sra. Alíce, considerada milha familia em Piracicaba.

E a todos, que de alguma maneira contribuíram para a realização deste trabalho. 


\section{ÍNDICE}

Página

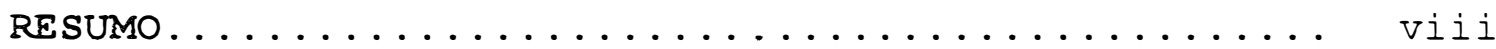

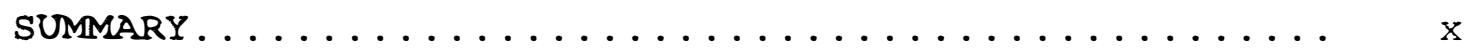

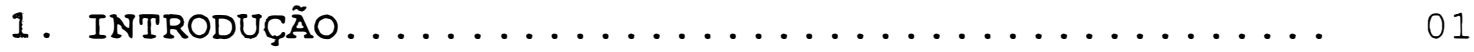

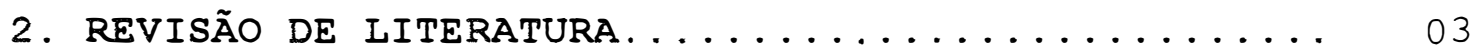

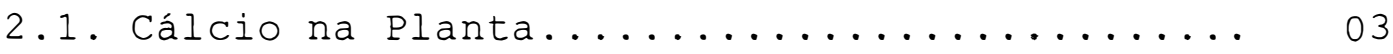

2.2. Cálcio na Qualidade de Sementes.......... 08

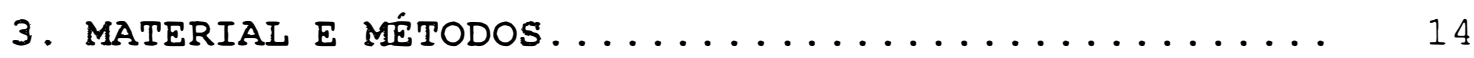

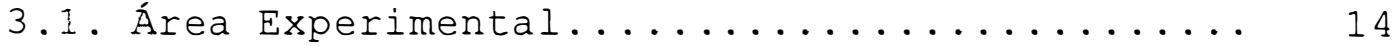

3.1.1. Local e Época ................... 14

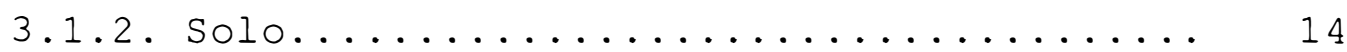

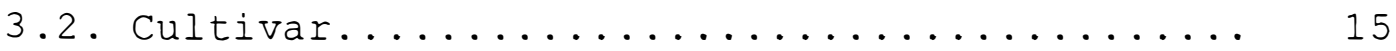

3.3. Instalação dos Experimentos............ 15

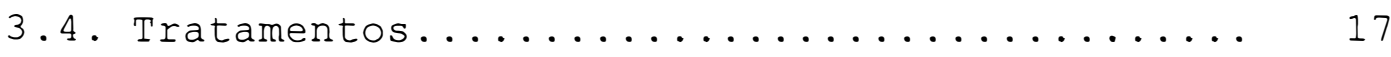

3.5. Condução dos Experimentos............... 19

3.6. Colheita e Preparo das Sementes........... 19

3.6.1. Teste de Uniformidade.............. 20

3.6.2. Tratamento Eungicida............... 20

3.7.Qualidade Física e Fisiológica das Sementes 21

3.7.1. Grau de Umidade................. 21

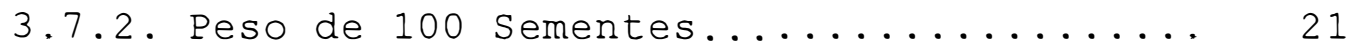

3.7.3. Teste de Germinação................ 21

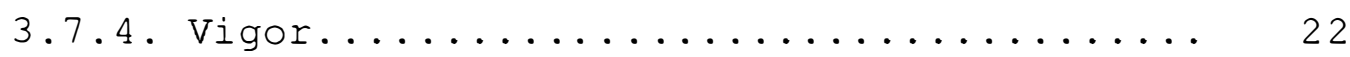

3.7.4.1. Primeira Contagem de Germinação..... 22

3.7.4.2. Envelhecimeto Acelerado......... 22

3.7.4.3. Condutividade Elétrica.......... 23

3.7.4.4. Emergência das plântulas em campo... 23

3.7.4.5. Lixiviação de potássio na semente... 23

3.7.5. Macronutrientes nas semente.......... 24

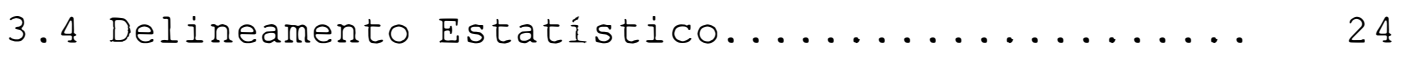




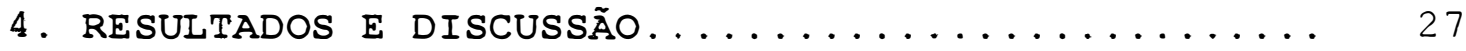

4.1 Experimento I (Área com calagem).......... 27

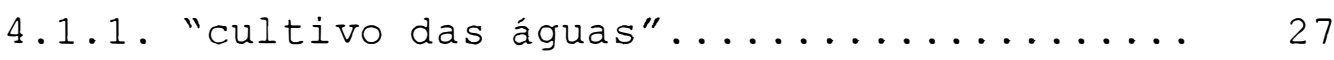

4.1.1.a. Primeira Etapa de Avaliação....... 27

4.1.1.b. Segunda Etapa de Avaliação........ 38

4.1.2. "cultivo da seca"................. 44

4.1.2.a. Primeira Etapa de Avaliação....... 44

4.1.2.b. Segunda Etapa de Avaliação........ 55

4.1.3. Considerações Gerais I............. 60

4.2 Experimento II (Área sem calagem)........... 62

4.2.1. "cultivo das águas".............. 62

4.2.1.a. Primeira Etapa de Avaliação......... 62

4.2.1.b. Segunda Etapa de Avaliação........ 74

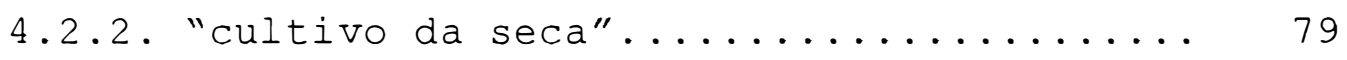

4.2.2.a. Primeira Etapa de Avaliação....... 79

4.2.2.b. Segunda Etapa de Avaliação........ 90

4.2.3. Considerações Gerais II............ 95

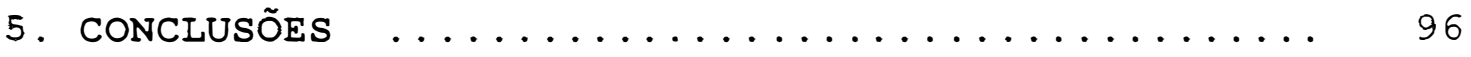

6. REFERÊNCIAS BIBLIOGRÁFICAS ................ 97

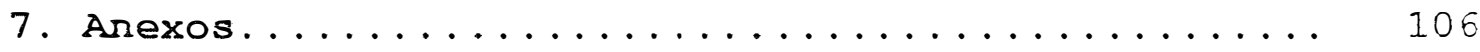




\title{
AVALIAÇÃO DA QUALIDADE FÍSICA E FISIOLÓGICA DE SEMENTES DE AMENDOIM (Arachis hypogaen L.) SUBMETIDO A DIFERENTES FONTES DE CÁlCIO COMBINADAS A ÉPOCAS E MODOS DE APLICAÇÃO
}

\author{
Autor: Maria Cristina Mingues Spinola \\ Orientador: Prof.Dr.Silvio Moure Cicero
}

RESUMO

É amplamente conhecido o fato da cultura do amendoim ser muito exigente em cálcio, sendo este elemento essencial na obtenção de altos rendimentos e melhor qualidade do produto obtido.

Entretanto, poucas são as pesquisas que vão além da avaliação dos efeitos do cálcio nos componentes de produção e na produção da cultura, raramente chegando à avaliação da qualidade física e fisiológica das sementes produzidas.

Neste contexto, o presente trabalho, conduzido em área experimental e no Laboratório de Análise de Sementes da Escola Superior de Agricultura "Luiz de Queiroz" da Universidade de São Paulo, teve como objetivo: avaliar a qualidade física e fisiológica de sementes de amendoim CV. Tatu, produzidas por plantas submetidas a diferentes fontes de cálcio combinadas a épocas e modos de aplicação.

Para tanto foram realizados dois

experimentos, um em área com calagem (saturação de bases a 70\%), no qual o calcário também se traduziu como fonte de 
fornecimento de cálcio e outro, em área sem calagem. Para ambos os experimentos foi relizada adubação de semeadura a base de fósforo ( $80 \mathrm{Kg} / \mathrm{ha}$ de $\mathrm{P}_{2} \mathrm{O}_{5}$ ) e potássio (30kg/ha de $\left.\mathrm{K}_{2} \mathrm{O}\right)$.

A distribuição das parcelas em campo se deu em blocos casualizados com 3 repetições, cujos tratamentos foram: doses de gesso agrícola (0,400,800, 1200 kg/ha), épocas (semeadura, florescimento) e modos de aplicação (área total e sulco).

Os experimentos foram repetidos na época da seca, visando-se verificar 0 efeito residual dos tratamentos.

A avaliação da qualidade física e fisiológica das sementes realizada em duas épocas 10 e 6 meses de armazenamentol foi avaliada por meio dos seguintes parâmetros: grau de umidade, peso de 100 sementes, germinação, vigor ( $1^{\text {a }}$ contagem de germinação, envelhecimento acelerado, condutividade elétrica, lixiviação de potássio, emergência em campol e determinação dos macronutrienetes nas sementes.

A interpretação dos resultados permitiram concluir que: No "cultivo das águas", em área sem calagem, o gesso agrícola é benéfico para a qualidade das sementes de amendoim, independentemente das doses, épocas e locais de aplicação do mesmo. Em área com calagem, aplicaçào de gesso agrícola é dispensável, uma vez que não afetou a qualidade das sementes. O teor de cálcio nas sementes não se relaciona com a qualidade das mesmas. 
Evaluation of physical and physiological quality of groundnut (Arachis hypogaea L.) under different calcium sources combined application seasons and methods

Author:Maria Cristina Mingues Spinola

Adviser:Prof. Dr. Silvio Moure Cicero

\section{SUMMARY}

It is widely known that the groundnut crops are highly exigent on calcium, so that this element is essencial to obtain high yields and a better quality product.

However, there are few research works that go any further the evaluation of calcium effects on the yield components and crop production, they seldom reach the evaluation of physical and physiological quality of produced seeds.

In this contex, the current research work, carried out in the experimental field and in the seed Analysis Laboratory of Escola Superior de Agricultura "Luiz de Queiroz", of the São Paulo University, has aimed: to evaluate the physical and physiological seeds quality of groundnut cV. Tatu, undergoing calcium fertilization with different sources of the element combined with application seasons and methods.

In onder to do so, two experiments has been

settled, one of them in a limed (bases saturation up to $70 \%$ ) area and the other one in a limeless area. A seed 
fertilization on a phosphorus (80 $\left.\mathrm{P}_{2} \mathrm{O}_{5} \mathrm{Kg} / \mathrm{ha}\right)$ and potassium ( $30 \mathrm{~K} 2 \mathrm{O} \mathrm{Kg} / \mathrm{ha}$ ) basis has been done for both experiments.

The field plot distribuition followed a random block desing with 3 repeats, whose treatments were: phosphogypsum dose $(0,400,800,1200 \mathrm{Kg} / \mathrm{ha})$ season (planting, flowering) and application methods (total area and wells).

The experiments were repeated during dry season, to verify the residual effect of the treatments.

The evaluation of physical and physiological seed quality underbalsen in two seasons (0 and 6 months under storage) was done by the following parameters: moisture content, 100 seeds weight, germination, vigor ( 1 st. germination count, accelerated ageing, electrics conductivity, potassium leaching, field seedling production) and determination of seed macronutrients.

The results interpretation lead to the following conclusions: the "rainy season crops", in limeless area, phosphogypsum application brings benefits to groundnut seed quality, independent of its dose, application season and placement. In the limed area, the phosphogypsum application is dispensable, once it did not affect the seed quality the calcium lewl of the seeds does not correlate to their quality. 


\section{INTRODUÇÃO}

A cultura do amendoim (Arachis hypogae L.) se reveste de grande importância econômica a nível mundial, uma vez que o produto obtido é largamente utilizado na alimentação humana e principalmente como matéria-prima para a produção de óleos comestíveis e ração animal.

No Brasil, nos últimos anos, cresceu o

interesse por esta cultura nas regiões cultivadas com a cana-de-açúcar, quando da renovação dos canaviais. Sendo uma leguminosa de ciclo curto (100 a 110 dias), tem possibilitado redução de custo de implantação de canaviais, além de melhoria nas condições físicas e químicas do solo, através da fixação do nitrogênio atmosférico e de incorporação dos restos culturais. Isto justifica o interesse cada vez maior de se conhecer as reais necessidades da cultura, para que se possa obter maior rendimento nas colheitas e maior produção de massa verde.

É amplamente conhecido o fato da cultura do amendoim ser muito exigente em cálcio, sendo este elemento essencial na obtenção de altos rendimentos e melhor qualidade do produto obtido.

Os solos brasileiros normalmente apresentam baixos teores de cálcio e muitos deles são pobres também em enxofre. o gesso agrícola $\left(\mathrm{CaSO}_{4}\right.$. $\left.2 \mathrm{H}_{2} \mathrm{O}\right)$, por apresentar maior solubilidade e maior mobilidade no solo que o calcário, vem sendo utilizado com sucesso em outros paises para corrigir 
- excesso de alumínio trocável de subsuperfície e para fornecer cálcio e enxofre à cultura do amendoim.

Todavia, para a plena expansão da cultura do amendoim no Brasil, é necessário que a oferta de sementes em quantidade e qualidade não se constitua no fator limitante do processo.

Sabe-se que o objetivo fundamental de um sistema de produção de sementes é a obtenção de materiais de alta qualidade genética, física, fisiológica e sanitária, permitindo que as características superiores dos cultivares, obtidos pela pesquisa, sejam disponíveis aos agricultores.

A idéia de que a qualidade da semente, quanto ao aspecto fisiológico, é influenciada pelos componentes do meio onde a planta mãe se desenvolve, é preconizada pelo homem desde o século XVIII. Sendo assim, o conhecimento de que os fatores ambientais responsáveis pelo crescimento e desenvolvimento das culturas (clima e solo), em uma concepção genérica, afetam a qualidade fisiológica da semente, leva a admitir que fatores mais específicos, como teor de nutrientes do solo, possam vir a determinar influências mais definidas com relação ao desempenho das sementes.

Entretanto, a literatura revela que são poucas as pesquisas que vão além da avaliação dos efeitos do cálcio nos componentes de produção e produção da cultura, raramente chegando à avaliação da qualidade física e fisiológica das sementes produzidas.

Como contribuição a esse fato é que foi desenvolvido o presente trabalho, tendo como objetivo avaliar a qualidade física e fisiológica de sementes de amendoim submetidas a diferentes fontes de cálcio combinadas a épocas e modos de aplicação 


\section{REVISÃO DE LITERATURA}

\subsection{Cálcio na Planta.}

o cálcio é um elemento essencial na nutrição vegetal, desempenhando na planta as seguintes funções estruturais: formação do pectato de cálcio na parede celular, formação e funcionamento da membrana celular, ativação de enzimas (amilase e fosfatase), germinação do grão de polén e crescimento do tubo polínico, além de afetar a ação da redutase do nitrato (MALAVOLTA, 1980). Segundo GUILHERME (1985) essas funções refletem em uma melhor formação e crescimento das raízes; aumento no vigor das plantas; aumento na produção de grãos e sementes, bem como estimula a nodulação e a fixação do nitrogênio em leguminosas

$\mathrm{Na}$ cultura do amendoim, o cálcio se caracteriza por ser um importante nutriente para frutificação, formação e desenvolvimento das sementes, sendo que os requerimentos nutricionais dessa cultura em cálcio são altos. Este elemento é absorvido pelas raízes, ginóforos e cascas do fruto em formação. Deficiências deste elemento no solo diminuem o índice de fertilidade das flores, reduz o número de ginóforos formados e provoca a formação de vagens chochas, com cascas frágeis; as sementes são mal formadas e a plúmula pode se apresentar parda- 
escura (COX \& REID, 1964; HARRIS \& BROLMAN, 1966; COX et al., 1976; GODOY et al., 1982).

Segundo Prevot ${ }^{i}$ citado por EORNASIERI

(1987), a cultura do amendoim apresenta dois períodos críticos, em termos nutricionais. O primeiro ocorre no florescimento, com o aumento do metabolismo da planta, quando ocorre também o aumento dos teores de nitrogênio, fósforo e cálcio na mesma. O segundo acontece durante a penetração dos ginóforos no solo, quando estes apresentam alta capacidade de absorção de nutrientes, os quais devem estar disponíveis na área de penetração.

Com relação a mobilidade do cálcio na planta, WALKER (1975) concluiu que, aparentemente, o elemento não se move dos pontos de crescimento da planta ao fruto em desenvolvimento, o que está de acordo com o expressado por HANGER (1979) sobre o movimento unidirecional do cálcio, que vai da raiz aos tecidos meristemáticos e quando depositado nestes, não é reciclado a uma condição de deficiência de cálcio. Também WIERSUM (1979), verificou que o cálcio não é transportado ao longo dos vasos do xilema ao fruto em desenvolvimento e que o floema é incapaz de conduzir cálcio suficiente aos ginóforos, o que abre a possibilidade de concluir que 0 fruto absorve o cálcio diretamente do solo. Segundo COELHO \& TELLA (1967a, 1967b) os resultados dos trabalhos realizados com o cultivar Tatu, em que foi aplicado, calcário como fonte de cálcio, confirmaram que as concentrações de cálcio na cultura do amendoim teve seus valores aumentados com a idade das plantas. Para a cultura das águas, 90\% do total da matéria seca das plantas e dos nutrientes foram acumulados entre 0

'Prevot, P. Croissance et development de L'Arachide Oléagineux : 4: 1-11, 1949 
início da frutificação e o início da maturação das vagens (30 a 100 dias). No cultivo da seca, este período ocorreu mais cedo, isto é, entre o inicio da floração até semanas após o início da frutificação. A adubação ocasionou aumento na concentração dos nutrientes nas diferentes partes da planta sendo que 93\% do cálcio foi encontrado na parte vegetativa. Resultados semelhantes foram observados por PIVETTA, (1978) e SICHMANN et al. (1970), que constataram a absorção mais acentuada de cálcio após o florescimento.

A grande justificativa para que sejam adotadas práticas para manter um alto suprimento de cálcio, na cultura do amendoim, na zona de frutificação, foi apresentado por CHAHAL \& VIMANI (1973 e 1974), em que foi constatado que $90 \%$ do Ca dos grãos é absorvido na fase de frutificação. SICHMANN (1972), verificou também que a deficiência deste elemento neste período, causa o chochamento de grãos, levando à obtenção de vagens inteiramente sem grãos ou com um ou mais grãos subdesenvolvidos.

Baseados nestas peculiaridades da nutrição da cultura do amendoim, relativas à absorção e translocação do cálcio na planta, assim como a sua influência no rendimento agrícola e na qualidade do produto, muitos pesquisadores vêm realizando trabalhos visando estabelecer fontes, doses e épocas de aplicação de cálcio, que forneçam melhores resultados.

O amendoim é muito tolerante em relação ao pH do solo. Nas regiões produtoras do mundo, é cultivado sob pH variando de 4 a 8 , sendo que em solos com valores muito baixos, deficientes em cálcio, a aplicação de calcário normalmente é efetuada para elevar o teor deste elemento(GODOY et al., 1982; COX et al., 1982). 
Embora o objetivo principal da calagem seja a neutralização do alumínio e/ou manganês trocáveis, ela também se constitui em fonte de fornecimento de cálcio, principalmente para aumentar a disponibilidade do nutriente na zona de frutificação da planta no solo (ADAMS \& PEARSON, 1970; ADAMS \& HARTZOG, 1980; FORNASIERI, 1987; SICHMANN et al., 1982 e QUAGGIO et al., 1982).

Conforme GODOY et al. (1982), as fontes de cálcio que podem ser utilizadas na cultura são: calcários dolomíticos, calcíticos e sulfato de cálcio (gesso agrícola). O gesso agrícola constitui-se em excelente fonte de cálcio por ser uma das formas mais solúveis (WALKER et al., 1979). Segundo VITTI et al. (1986), o gesso agrícola tem dupla função, além de servir como fonte de cálcio e de enxofre para as culturas, neutraliza o excesso de alumínio tóxico de sub-superfície e enriquece em cálcio as camadas mais profundas do solo, permitindo assim 0 maior desenvolvimento do sistema radicular, resultando maior resistência à seca e maior aproveitamento dos nutrientes do solo e dos adubos aplicados. Entretanto, o momento de aplicação dessas fontes é bastante importante, uma vez que - amendoim absorve o elemento através dos ginóforos, sendo assim necessário que ele esteja disponível na zona de frutificação.

Com relaçào a essas fontes de cálcio (calcário e gesso agrícola), alguns autores, como Reed \& Brandy ${ }^{2}$ citado por SICHMANN et al.(1972) preferem utilizar - gesso agrícola no lugar do calcário. Por outro lado, QUAGGIO et al. (1982) verificaram que o gesso agrícola pode provocar a lixiviação de bases trocáveis, especialmente o

\footnotetext{
${ }^{2}$ Reed, J.F.;Brady, N.C. Time and method of supplying calcium as factors affecting production of peanuts Journal American Socied Agronomy : 40: 980-996, 1948
} 
$\mathrm{K}^{+}$e $\mathrm{O} \mathrm{Mg}^{2+}$. Os autores verificaram que 18 meses após a aplicação de gesso agrícola no solo, o teor de $\mathrm{K}^{+}$trocável na camada arável decresceu de 0,19 para 0,12 emg/100 ml de solo e o teor de $\mathrm{Mg}^{++}$trocável de 0,3 para 0,1 emg/100 ml de solo. Verificaram também que a mistura de gesso agrícola + calcário reduziu a lixiviação de bases. Cabe ressaltar que esta lixiviação de bases só será prejudicial se estas forem levadas para fora da zona das raízes.

Em vista do exposto, conclui-se que para obtenção de alto rendimento e boa qualidade de sementes, é fundamental a presença de cálcio na zona de frutificação e no período de formação dos frutos, o que pode ser conseguido pela aplicação de gesso agrícola em cobertura, já o calcário aplicado em cobertura no florescimento não teve a mesma eficiência do gesso agrícola, SICHMANN et al. (1982).

A aplicação de gesso agrícola em cobertura, no início do florescimento, é uma prática rotineira em regiões que se cultiva essa leguminosa nos Estados Unidos (COX et al., 1982) e na Europa (GEUS, 1973), em doses variáveis de 450 a $700 \mathrm{Kg} / \mathrm{ha}$ do produto.

Em nossas condições, PIVETTA (1978) e EERREIRA et al. (1979), estudaram o efeito de épocas e doses de gesso agrícola em amendoim, Cultivar Tatu V-53, em latossolo Vermelho-Escuro fase arenosa, e verificaram que a dose de $500 \mathrm{~kg} / \mathrm{ha}$ aplicado no início do florescimento revelou o melhor desempenho com aumentos de 30\% de amendoim em casca.

QUAGGIO et al. (1982), em Latossolo Roxo Distrófico de Campinas-SP, também verificaram que o gesso agrícola é excelente fonte de cálcio para o amendoim e que 
a sua aplicação no início do florescimento foi mais eficiente do que a feita a lanço pouco antes da semeadura.

FORNASIERI (1985), trabalhando em um

Latossolo Roxo Distrófico, avaliou o efeito do calcário e do gesso agrícola isoladamente e da mistura de ambos, sobre diversas características produtivas e comerciais do amendoim, constatando que o tratamento que recebeu 500 Kg/ha de gesso agrícola em cobertura foi superior aos que receberam calcário ou gesso agrícola a lanço antes da semeadura, não diferindo, entretanto, daquele que recebeu a mistura desses dois corretivos.

VITTI (1986), baseado em diversos trabalhos de pesquisa, recomendou $500 \mathrm{Kg} / \mathrm{ha}$ de gesso agrícola para solos arenosos, 500 a $1000 \mathrm{Kg} / \mathrm{ha}$ de gesso agrícola para solos de textura média e 1000 a $1500 \mathrm{Kg} / \mathrm{ha}$ de gesso agrícola para solos argilosos.

Esta maior eficiência do gesso agrícola não deve ser atribuída somente ao cálcio, mas também, devido a presença do enxofre 0 qual encontra-se em quantidades apreciáveis no gesso agrícola(cerca de 15 a 16\% de S).

\subsection{Cálcio na Qualidade de Sementes}

Uma planta bem nutrida reúne condições de produzir maior quantidade de sementes, aliada a uma melhor qualidade, haja visto que elas terão condições de resistir mais facilmente a condições adversas que surjam no período de produção. A disponibilidade de nutrientes influi na formação do embrião e dos órgãos de reserva, assim como na composição química da semente e dessa forma terão consequentemente efeitos sobre 0 vigor e qualidade da semente (SÁ, 1990). 
Conforme considerações de TOLEDO \& MARCOS EILHO (1977), a vitalidade das sementes depende em parte do vigor dos seus ancestrais, motivo pelo qual as terras cultivadas com a finalidade de produção de sementes devem possuir boa fertilidade, além de receber adubações equilibradas. Neste ponto, é importante realçar que o potencial de armazenamento é outro fator importantíssimo a se considerar na qualidade de sementes, tendo-se em vista que em várias situações uma semente colhida apresentando altos padrões de qualidade, pode sofrer efeitos de deterioração e ficar rapidamente imprória para a semeadura. Nestas situações, uma nutrição equilibrada, fatores como espécie, cultivar, condições climáticas nas fases de formação e maturação da semente (principalmente alta umidade relativa do ar e alta temperatura ou déficit hídrico prolongado) afetam a qualidade fisiológica da semente, determinando um maior ou menor periodo de armazenamento.

$$
\text { Conforme DELOUCHE (1980) as plantas }
$$

desenvolvem uma extraordinária capacidade de ajustar a produção de sementes aos recursos disponíveis. A resposta típica das plantas à baixa fertilidade do solo ou à falta de água é inicialmente na quantidade de sementes produzidas, antes que a redução na sua qualidade. As poucas sementes produzidas sob condições marginais são usualmente tão viáveis e vigorosas como as sementes produzidas sob as condições favoráveis.

Entretanto, SÁ (1990), verificou que o. aspecto nutricional das plantas tem se mostrado em vários trabalhos como um fator que afeta tamanho, peso e vigor das sementes, sendo que em muitas situações estes efeitos podem estar ligados à permeabilidade e integridade das membranas 
dos tecidos das mesmas, considerar-se que vários nutrientes atuam como ativadores enzimáticos ou como constituintes destas membranas, como é o caso do cálcio.

O exame da literatura revela que 0 reconhecimento da importância do cálcio para o amendoim vem de longa data, conforme comentou GODOY et al. (1982).

Efeitos significativos do cálcio sobre a germinação de sementes de amendoim foram verificados por HALLOCK \& ALLISON (1980) que estudando o efeito do mesmo, em duas localidades da Virginia-USA, constataram valores maiores que $85 \%$ de germinação para os tratamentos que receberam cálcio, contra 76\% da testemunha, no primeiro local. No outro local, apenas alguns tratamentos apresentaram resultados melhores, mas em média, a porcentagem de germinação foi menor que a testemunha, motivado, segundo os autores, pela baixa precipitação pluvial durante a fase de maturação, o que comprometeu severamente a produção.

Em experimentos conduzidos em vasos, COX \& REID (1964), HARRIS \& BROLMANN (1966) e SULLIVAN et al. (1974) constataram que sementes de amendoim produzidas sob deficiência de cálcio podem apresentar um escurecimento na base da plúmula da semente, que se reflete em baixo poder germinativo das mesmas.

BELL (1985) encontrou relações positivas, altamente significativas entre conteúdo de cálcio na semente de amendoim, cv.Virginia Bunch e teor deste nutriente no solo, e uma relação inversa entre conteúdo de cálcio na semente e no solo com os sintomas de escurecimento da plúmula. Segundo o mesmo autor, as relações entre o teor de cálcio nas sementes e a proporção destas com o sintoma de escurecimento da plúmula e 
germinação, indicaram que a concentração crítica de cálcio observada na semente de amendoim é maior que 420 ppm (0,042\%), obtido por COX et al.(1976) para sementes de amendoim, cv.florygiant, mas está dentro da faixa de 450$680 \mathrm{ppm}(0,045 \%-0,068 \%)$ proposta por SULLIVAN et al. (1974) para sementes de CV.NC5. O pesquisador afirmou que a concentração de cálcio na semente seria um importante parâmetro de qualidade para a semente de amendoim.

Ainda com relação à concentração de cálcio na semente, HALLOCK \& ALLISON (1980), em dois anos de experimentação com o cultivar Florygiant, observaram correlação significativa entre o teor de cálcio nas sementes e o poder germinativo das mesmas.

De acordo com GILLIER \& SILVESTRE (1970), a ação do cálcio seria atribuida a maior mobilização de nitrogênio para os frutos, o que suportaria colocações de BEWLEY \& BLACK (1985) que enfatizaram relação positiva entre teor de proteínas nas sementes e germinação.

Quanto aos efeitos do cálcio no peso médio das sementes, os resultados são contraditórios. Efeitos positivos no peso das sementes foram observados por FERREIRA et al. (1979) e COFFELT \& HALLOCK (1986), e negativos por MAEDA et al. (1986), QUAGGIO (1987) et al.(1990) e NAKAGAWA et al.(1990). Enquanto SICHMANN et al.(1982), FORNASIERI (1985), CAIRES (1990) e ROSSETO (1993) constataram que a aplicação de cálcio no amendoim não causou alteração no peso médio das sementes.

COFEELT \& HALLOCK (1986) trabalharam com vários cultivares de amendoim do grupo Virginia, em solos de baixa e alta fertilidade. Em solos de alta fertilidade estudaram também a aplicação de cálcio, sob a forma de sulfato de cálcio, no início da formação dos ginóforos, e 
verificaram um aumento significativo na produção, no peso de 100 sementes e na germinação. Enfatizaram a importância deste nutriente na produção do amendoim do grupo Virginia mesmo em solo de alta fertilidade.

Em estudos realizados por MAEDA et al. (1986) sobre o efeito da calagem e adubação com NPK na qualidade de sementes de amendoim, cv.Tatu, produzidas na estação "das águas", verificou-se que a aplicação de calcário (com ou sem NPK) diminuiu o peso médio das sementes, porém apresentou efeito positivo na germinação e vigor das sementes, detectado durante os 15 meses de armazenamento em condições normais de ambiente. Praticamente, não houve efeito aditivo de NPK e calcário na qualidade fisiológica das sementes. As sementes produzidas na presença de calcário e NPK + calcário mantiveram germinação bastante alta por todo o período de armazenamento, tendo apresentado, ao final dos 15 meses, as porcentagens de germinação de 92,5 e 90,5, respectivamente, enquanto as provenientes dos tratamentos testemunha e NPK exibiram no mesmo período, os índices de germinação de 57,5 e $71,5 \%$ respectivamente.

VIEIRA et al. (1986) concluíram que na região de Dourados - MS, a aplicação de calcário não influenciou o vigor das sementes de amendoim, cultivar Tatu, avaliado através dos pesos de matéria seca de plântulas e índice de velocidade de emergência de plântulas .

Os efeitos de adubos fosfatados, com e sem calagem, na qualidade de sementes de amendoim, cv.Tatu Branco, foram também estudados por NAKAGAWA et al. (1990), em duas localidades do Estado de São Paulo, em duas épocas sucessivas de cultivo - "das águas" e "da seca", onde se 
avaliou o efeito residual dos adubos e do calcário. Verificaram os autores que a calagem proporcionou sementes de maior germinação, vigor e produção, tanto no cultivo das águas (efeito imediato) como no cultivo da seca (efeito residual). Entretanto, em um dos municipios, o efeito benéfico da calagem foi mais pronunciado no cultivo das águas. Os mesmos pesquisadores também observaram que em relação ao peso de 100 sementes, as respostas à aplicação de calcário apresentaram-se favoráveis apenas no cultivo da seca (efeito residual) em ambas as localidades.

Em trabalho mais recente, ROSSETO (1993), estudando o efeito da calagem e do momento de colheita na produção e na qualidade de sementes de amendoim, cv.Botucatu, no cultivo das águas, concluiu que deve-se realizar a calagem visando a qualidade, pois embora esta operação não tenha afetado a produção e seus componentes, proporcionou sementes que amadureceram antes e mantiveram por maior período de tempo a sua qualidade fisiológica.

Em vista da controvérsia dos resultados obtidos pelos vários autores, aliado a escassez de trabalhos sobre o assunto, estudos sobre a influencia do cálcio na qualidade física e fisiológica de sementes se fazem necessários. 


\section{MATERIAL E METODOS}

\section{1. Área Experimental}

\subsubsection{Local e época}

O presente trabalho foi desenvolvido em área experimental denominada Fazenda Sertãozinho, pertencente a ESALQ/USP, em Piracicaba, São Paulo, localizada geograficamente a $22^{\circ} 42^{\prime} 30^{\prime} '$ de latitude sul, $47^{\circ} 38^{\prime}$ 00'' de longitude Oeste e $580 \mathrm{~m}$ de altitude.

A pesquisa, em condições de campo, foi conduzida durante o período compreendido entre a segunda quinzena do mês de setembro de 1992 (época da realização da análise do solol e dezembro de 1993. Foram feitos dois cultivos: das águas e da seca.

\section{1 .2 . Solo}

O presente experimento foi instalado em solo classificado como Latossolo Vermelho-Amarelo, álico, textura média, anteriormente cultivado com milho e submetido a pousio durante 0 ano agrícola precedente a condução do experimento. Este solo é representativo em relação aos solos tradicionais da cultura no estado de são Paulo. Pela análise de solo, apresentada na Tabela 01 , pode-se observar a qualidade deste solo para a realização do presente estudo. 
Tabela 01:Análise química do solo da área experimental antes da sua correção.

\begin{tabular}{|c|c|c|c|c|c|c|c|c|c|c|}
\hline \multirow{2}{*}{$\begin{array}{c}\text { Amostragem } \\
*\end{array}$} & \multirow{2}{*}{$\begin{array}{c}\text { P res. } \\
\left(\mathrm{mg} / \mathrm{dm}^{3}\right)\end{array}$} & \multirow{2}{*}{$\begin{array}{l}\text { M.O. } \\
(\%)\end{array}$} & \multirow{2}{*}{$\begin{array}{c}\mathrm{pH} \\
\mathrm{CaCl}_{2}\end{array}$} & $\mathbf{K}$ & Ca & Mg & $\mathbf{H}+\mathbf{A l}$ & $\mathbf{S}$ & $\mathbf{T}$ & \multirow{2}{*}{$\begin{array}{c}\mathrm{V} \\
(\%)\end{array}$} \\
\hline & & & & & & \multicolumn{4}{|c|}{$\left(\mathrm{m} \cdot \mathrm{mol}_{\mathrm{c}} \cdot \mathrm{dm}^{-3}\right)$} & \\
\hline 01 & 6,2 & 2,78 & 4,45 & 0,10 & 0,72 & 0,34 & 3,61 & 1,20 & 4,80 & 24,3 \\
\hline 02 & 4,3 & 2,54 & 4,40 & 0,05 & 0,63 & 0,28 & 3,61 & 1,00 & 4,60 & 21,0 \\
\hline 03 & 8,2 & 2,94 . & 4,40 & 0,12 & 0,22 & 0,29 & 3,81 & 0,60 & 4,40 & 14,2 \\
\hline 04 & 5,4 & 2,7 & 4,35 & 0,09 & 0,54 & 0,31 & 3,61 & 0,90 & 4,60 & 20,7 \\
\hline $\begin{array}{r}\text { ^01 - área qu } \\
02 \text { - área qu } \\
03 \text { - área qu } \\
04 \text { - área qu }\end{array}$ & $\begin{array}{l}\text { ecebeu } \\
\text { e não recek } \\
\text { e não recek }\end{array}$ & calac & em $10-$ & $20 \mathrm{cl}$ & de & rofur & $\begin{array}{l}\text { de) } \\
\text { dade) } \\
\text { didade) }\end{array}$ & & & \\
\hline
\end{tabular}

\subsection{Cultivar}

Utilizou-se a cultivar de amendoim Tatu, cujo ciclo de maturação é curto. A escolha deste material genético se baseou na sua maior suscetibilidade à deficiência de cálcio e pelo fato de ser utilizado em aproximadamente 95\% da área cultivada no Brasil.

\subsection{Instalação dos Experimentos}

Foram instalados dois experimentos um com calcário (Experimento I) e outro sem calcário (Experimento II), sendo a dosagem de calcário dolomítico (PRNT=65\%) calculada para elevar a saturação de bases a 70\%. Em seguida, o solo foi preparado através de aração a $0,30 \mathrm{~m}$ e gradeação para nivelamento do mesmo.

o solo permaneceu em pousio aproximadamente durante 30 dias, quando então aplicou-se o herbicida trifluralin à dosagem de 1,0 litro por hectare em présemeadura e incorporado ao solo. 
As parcelas experimentais foram demarcadas após a abertura mecanizada dos sulcos de semeadura. Todas as parcelas receberam adubação de $80 \mathrm{Kg} / \mathrm{ha}$ de $\mathrm{P}_{2} \mathrm{O}_{5}$ (superfosfato triplo) e de $30 \mathrm{Kg} / \mathrm{ha}$ de $\mathrm{K} 2 \mathrm{O}$ (cloreto de potássio) na semeadura de ambos os cultivos, com exceção do tratamento controle total. Esta adubação foi dimensionada de acordo com a análise química do solo e localizada no fundo dos sulcos em mistura com o mesmo.

A parcela experimental, foi constituída por 8 linhas. Cada linha tinha 4,0 m de comprimento, que associado ao espaçamento de $0,50 \mathrm{~m}$ entre linhas, configurou parcela com 4,0 m de largura. Cada linha lateral constituiu-se em bordadura. Também para efeito de bordadura entre parcelas dentro de blocos, foi respeitada uma distância de $0,50 \mathrm{~m}$. As 6 linhas centrais representaram a área útil de cada parcela, das quais foram obtidas as sementes para avaliação da qualidade física e fisiológica.

Considerando-se os 2 experimentos (áreas com e sem calagem) foram conduzidos 6 blocos ( 3 para área com calagem e 3 para a área sem calagem) com 16 parcelas cada, totalizando 96 parcelas de campo e $1.536 \mathrm{~m}^{2}$ de área verde.

As sementes já tratadas com fungicida, foram semeadas nos sulcos previamente adubados e cobertas com aproximadamente 0,03 $\mathrm{m}$ de terra. A densidade de semeadura foi de 20 sementes por metro linear e o espaçamento entre linhas de $0,50 \mathrm{~m}$.

O amendoim 'das águas' foi semeado em 11/11/92 e colhido em 2/03/93 correspondendo a 111 dias de ciclo vegetativo. Já, o amendoim 'da seca' foi semeado em 23/03/93 e colhido em 27/07/93, correspondendo a 126 dias de ciclo vegetativo 


\subsection{Tratamentos}

Foram conduzidos dois experimentos de campo, correspondentes a duas áreas experimentais, sendo uma com calagem (Experimento I) e outra sem calagem (Experimento II). Em cada experimento foram aplicados os seguintes tratamentos:

\section{Tratamentos com aplicação de gesso}

agrícola:

$$
\mathrm{T} 1=\mathrm{GlPL}-400 \mathrm{Kg} / \mathrm{ha} \text { de gesso agrícola, }
$$

aplicado na semeadura de forma localizada nos sulcos.

$\mathrm{T} 2=\mathrm{GlEL}-400 \mathrm{Kg} / \mathrm{ha}$ de gesso agrícola, aplicado no início do florescimento de forma localizada lateralmente às linhas.

T3= GIPAT - $400 \mathrm{Kg} / \mathrm{ha}$ de gesso agrícola, aplicado na semeadura em área total.

$$
\mathrm{T} 4=\mathrm{GlEAT}-400 \mathrm{Kg} / \mathrm{ha} \text { de gesso agrícola, }
$$

aplicado no início do florescimento em área total em cobertura.

$$
\text { T5= G2PL - } 800 \mathrm{Kg} / \mathrm{ha} \text { de gesso agrícola, }
$$
aplicado na semeadura de forma localizada nos sulcos.

$$
\mathrm{T} 6=\mathrm{G} 2 \mathrm{FL}-800 \mathrm{Kg} / \mathrm{ha} \text { de gesso agrícola, }
$$

aplicado no início do florescimento de forma localizada lateralmente às linhas.

$$
\mathrm{T} 7=\mathrm{G} 2 \mathrm{PAT}-800 \mathrm{Kg} / \mathrm{ha} \text { de gesso agrícola, }
$$
aplicado na semeadura em área total.

$$
\text { T8 = G2EAT - } 800 \mathrm{Kg} / \mathrm{ha} \text { de gesso agrícola, }
$$

aplicado no início do florescimento em área total em cobertura.

$$
\text { T9= G3PL - } 1.200 \mathrm{Kg} / \mathrm{ha} \text { de gesso agrícola, }
$$
aplicado na semeadura de forma localizada nos sulcos. 
$\mathrm{T} 10=\mathrm{G} 3 \mathrm{FL}-1.200 \mathrm{Kg} / \mathrm{ha}$ de gesso agrícola, aplicado no início do florescimento de forma localizada lateralmente às linhas.

T11= G3PAT - $1.200 \mathrm{Kg} / \mathrm{ha}$ de gesso agrícola, aplicado na semeadura em área total (em cobertura).

T12= G3FAT - $1.200 \mathrm{Kg} / \mathrm{ha}$ de gesso agrícola, aplicado no início do florescimento em área total (em cobertura).

\section{Tratamentos adicionais (testemunhas, sem aplicação de gesso agrícola):}

TI3= GSL - sem aplicação de gesso agrícola, com aplicação localizada (nos sulcos) de enxofre na dosagem de $40 \mathrm{Kg} / \mathrm{ha}$ na semeadura.

T14= CPK - controle com apenas $P$ (Superfosfato Triplo) e $\mathrm{K}_{2} \mathrm{O}$.

T15 = CSSK - controle com apenas $P$ (Superfosfato Simples) e $\mathrm{K}_{2} \mathrm{O}$.

T16= CT - controle total (sem gesso agrícola, $P, K$ e S).

A aplicação de enxofre conforme explicitado no tratamento GSL, teve por objetivo compensar o efeito do enxofre contido no gesso agrícola, para melhor visualização do provável efeito isolado do cálcio. O enxofre foi aplicado apenas na semeadura, pois segundo Van RAIJlse aplicado no florescimento não estaria disponível na época de maior necessidade pela planta.

Houve dois tratamentos controle com apenas $P$ e K. Um deles recebeu a mesma fonte de fósforo que os tratamentos com aplicação de gesso agrícola (Superfosfato

${ }^{1}$ RAIJ, B.VAN. (Pesquisador Científico da Seção de Ferilidade do Solo do Instituto Agronômico de Campinas, São Paulo).Orientação pessoal, 1992. 
Triplo). O outro recebeu fósforo via Superfosfato Simples, visando-se à comparação de desempenho da cultura, sob este controle, com o controle anterior e com os tratamentos com gesso agrícola.

\subsection{Condução dos Experimentos}

- controle de plantas daninhas foi efetuado, quando necessário, através da aplicação de herbicidas ou capinas manuais, de acordo com a situação e época.

- controle de pragas e doenças foi feito sistematicamente, de acordo com os procedimentos normais exigidos pela cultura do amendoim, ou seja, controle químico preventivo, inicialmente para a ocorrência de pragas (tripes e lagarta do pescoço vermelho) e posteriormente para a ocorrência de doenças (cercosporiose). Foi utilizado o inseticida Monocrotophos (Nuvacron - 0,5 l/ha). Não foi constatado qualquer dano por pragas ou doenças, em nenhum dos cultivos.

\subsection{Colheita e Preparo das sementes}

As sementes colhidas nas áreas experimentais foram enviadas ao Laboratório de Análise de Sementes do Departamento de Agricultura da ESALQ/USP, onde foram classificadas e tratadas. Após a classificação e tratamento, parte delas entrou imediatamente em rotina de análise, e outra em armazenamento sob condições normais de ambiente durante 6 meses, com registro diário dos dados de temperatura e umidade relativa do ar. 


\subsubsection{Teste de Uniformidade(Classificação por peneiras)}

o objetivo da adoção deste teste foi o de se trabalhar com material o mais próximo possível do normalmente utilizado na comercialização de sementes de amendoim. Para tanto, de cada parcela de campo, foram retiradas duas sub-amostras de $100 \mathrm{~g}$ de sementes puras, que foram agitadas em peneiras manuais de crivos circulares (17/64", 18/64", 19/64", 20/64", 21/64", 22/64", 23/64" e 24/64"). As sementes retidas pelas peneiras indicadas, foram isoladamente pesadas, calculando-se a porcentagem de sementes retidas em números inteiros, segundo as prescrições estabelecidas pelas Regras para Análise de Sementes (BRASIL, M. A., 1992). A partir destas porcentagens definiu-se que sementes correspondentes às peneiras 18/64" a 22/64" seriam utilizadas nas determinações da qualidade física e fisiológica

\subsubsection{Tratamento fungicida}

Após a definição das peneiras, as sementes de cada parcela retidas nestas, passaram por um processo de catação manual, no qual as sementes visualmente danificadas e escuras foram descartadas, simulando o procedimento final do processo de beneficiamento de sementes de amendoim. Assim sendo, devido à alta incidência de fungos encontrados nesse material pré-selecionado quando da instalação de testes preliminares de germinação em rolo de papel, optouse pelo tratamento das sementes. Para tanto utilizou-se o fungicida Thiram contendo $70 \%$ dissulfeto de tetrametiltiuram (Rhodiauram 70), na dosagem de $250 \mathrm{~g}$ de i. a./100 $\mathrm{Kg}$ de sementes. 


\subsection{Qualidade Física e Fisiológica das Sementes}

No início e final do período de armazenamento (I e II Etapa de avaliação) respectivamente, foram conduzidos os testes para avaliação da qualidade das sementes, através dos métodos e procedimentos descritos a seguir:

\subsubsection{Grau de umidade}

Foi determinado pelo método da estufa, a $105{ }^{\circ} \mathrm{C}+$ ou $-3^{\circ} \mathrm{C}$, durante 24 horas, com duas sub-amostras por parcela, segundo as prescrições das Regras para Análise de sementes (BRASIL, M.A., 1992). Os resultados foram expressos em porcentagem média por parcela.

\subsubsection{Peso de 100 sementes}

Para realização da mencionada determinação, foram separadas , manualmente, oito sub-amostras de 100 sementes para cada uma das parcelas, as quais foram pesadas em balança com sensibilidade de centésimos de gramas, sendo tais procedimentos efetuados segundo prescrições estabelecidas pelas Regras para Análise de Sementes (BRASIL M.A., 1992).

\subsubsection{Teste de germinação}

o teste foi conduzido com duas sub-amostras de 50 sementes por parcela, em rolo de papel-toalha da marca germitest, umedecidos com água na quantidade equivalente a 2,5 vezes 0 peso do substrato seco, à temperatura de $25^{\circ} \mathrm{C}$. As avaliações foram efetuadas aos 5 e 10 dias após a instalação do teste, de acordo com os critérios estabelecidos nas Regras para Análise de Sementes 
(BRASIL, M.A., 1992) e o resultado expresso em porcentagem média de plântulas normais por parcela.

\subsubsection{Testes de Vigor}

\subsubsection{Primeira Contagem de Germinação}

O referido teste foi conduzido conjuntamente com o teste padrão de germinação item 3.7.3. e se constituiu do registro da porcentagem de plântulas normais encontradas no quinto dia após a instalação do teste de germinação, sendo os resultados expressos em porcentagem média de plântulas normais por tratamento.

\subsubsection{Envelhecimento Acelerado}

Foi efetuado com duas sub-amostras de 50 sementes por parcela. As sementes foram distribuidas sobre uma bandeja de tela de alumínio fixada no interior de uma caixa plástica tipo "gerbox", funcionando como compartimento individual (mini-câmara). No interior dessa mini-câmara foram adicionados $40 \mathrm{ml}$ de água e, em seguida, os gerbox adaptados foram levados a uma incubadora, conforme metodologia proposta pelo Comitê de Vigor da ASSOCIATION OF OFFICIAL SEED ANALYSTS (1983).

$\mathrm{Na}$ incubadora, regulada a $42^{\circ} \mathrm{C}$, as sementes permaneceram durante 48 horas. Após esse período, foram colocadas para germinar da mesma maneira descrita no ítem 3.7.3.; após cinco dias, foram avaliadas as plântulas, computando-se a porcentagem média de plântulas normais por parcela. 


\subsubsection{Condutividade elétrica}

0 teste foi realizado conforme a recomendação do Comitê de Vigor da ASSOCIATION OF OFFICIAL SEED ANALYSTS (1983).

Foram utilizadas 4 sub-amostras de 25 sementes por parcela, previamente escolhidas para remoção daquelas com tegumento danificado. Terminada a pesagem de cada sub-amostra (precisão de $0.01 \mathrm{~g}$ ), as sementes foram imersas em $75 \mathrm{ml}$ de água destilada, no interior de copos pláticos, sob temperatura de $20^{\circ} \mathrm{C}$, durante 24 horas. Decorrido esse período, a condutividade elétrica da solução foi determinada através de condutivímetro e os valores médios para cada parcela foram expressos em umhos por grama de sementes.

\subsubsection{Emergência das plântulas em campo}

Foi realizada com 4 sub-amostras de 50 sementes por parcela. As sub-amostra foram distribuída em um sulco com $2 \mathrm{~m}$ de comprimento e com 0,03 $\mathrm{m}$ de profundidade; a distância entre sulcos foi de 0,30 m. Contagem única foi efetuada aos 21 dias após a semeadura, determinando-se as porcentagens médias de emergência por parcela.

\subsubsection{Lixiviação de potássio}

Para esta avaliação foi adotada, basicamente, a metodologia desenvolvida por AMORIN (1978) e adaptada por MARCOS FILHO et al. (1982) e (1984), em pesquisa com sementes de soja.

De cada parcela foram retiradas 4 subamostras de 25 sementes, pesadas com precisão de 0,01 g. Em seguida foram imersas em $75 \mathrm{ml}$ de água destilada, no 
interior de copos plásticos, sob temperatura de $30^{\circ} \mathrm{C}$ durante 90 minutos. Os copos foram agitados no início e no final desse período, quando então foram retiradas alíquotas para as determinações de potássio lixiviados em fotômetro de chama. Os resultados médios por parcela foram fornecidos em ppm (partes por milhão) de potásio por grama de semente.

\subsubsection{Determinação de teores dos macronutrientes das sementes}

A análise do teor dos macronutrientes das sementes foi efetuada no Laboratório do setor de Nutrição Mineral de Plantas do Departamento de Química da ESALQ/USP. Para tanto, aproximadamente, $40 \mathrm{~g}$ de sementes de cada parcela foram enviadas para análise, de acordo com a metodologia proposta por BATAGLIA et al. (1983), sendo a leitura dos mesmos efetuada em espectrofotômetro de absorção atômica. Os resultados médios por parcela de cada nutriente nas sementes foram fornecidos em porcentagens.

\subsection{Delineamento Estatístico}

Para ambos os experimentos lárea com e sem calagem) foi utilizado o esquema fatorial $3 \times 2 \times 2$ com 4 tratamentos adicionais (testemunhas) em blocos casualizados com 3 repetições.

A análise de variância realizada para cada experimento, etapa de análise e cultivos encontra-se na tabela 2 .

A partir dos quatros tratamentos adicionais (testemunhas sem aplicação de gesso agrícola), montou-se os quatro contrates, que serão descritos a seguir. 
Contraste 1: confronto entre tratamentos com e sem aplicação de gesso.

$Y(1)=$ testemunhas vs. fatorial

$Y(1)=3 \mathrm{~T} 1+3 \mathrm{~T} 2+3 \mathrm{~T} 3+3 \mathrm{~T} 4-\mathrm{T} 5-\mathrm{T} 6 \ldots-\mathrm{T} 15-\mathrm{T} 16$

Contraste 2: confronto entre tratamentos com e sem aplicação de NPK

$\mathrm{Y}(2)=\mathrm{T} 1 \mathrm{Vs} . \mathrm{T} 2, \mathrm{~T} 3$ e $\mathrm{T} 4$

$\mathrm{Y}(2)=3 \mathrm{~T} 1-\mathrm{T} 2-\mathrm{T} 3-\mathrm{T} 4+0 \mathrm{~T} 5+0 \mathrm{~T} 6 \ldots+0 \mathrm{~T} 15+0 \mathrm{~T} 16$

Contraste 3: confronto entre tratamentos com aplicação de superfosfato simples e os tratamentos com aplicação de superfosfato triplo.

$Y(3)=\mathrm{T} 2$ vs. T3 e T4

$\mathrm{Y}(3)=0 \mathrm{~T} 1+2 \mathrm{~T} 2-\mathrm{T} 3-\mathrm{T} 4+0 \mathrm{~T} 5+0 \mathrm{~T} 6 \ldots+0 \mathrm{~T} 15+0 \mathrm{~T} 16$

Contraste 4: confronto entre os tratamentos com aplicação de superfosfato triplo com e sem aplicação de enxofre.

$\mathrm{Y}(4)=\mathrm{T} 3 \mathrm{VS} \cdot \mathrm{T} 4$

$\mathrm{Y}(4)=0 \mathrm{~T} 1+0 \mathrm{~T} 2+\mathrm{T} 3-\mathrm{T} 4+0 \mathrm{~T} 5+0 \mathrm{~T} 6 \ldots+0 \mathrm{~T} 15+0 \mathrm{~T} 16$

Toda a metodologia de análise estatística utilizada na presente pesquisa foi descrita por GOMES (1978) e desenvolvida com apoio de NOGUEIRA ${ }^{2}$

${ }^{2}$ NOGUEIRA, M.C.S. (Prof a Associada do Departamento de Matemática e Estatística da ESALQ/USP). Orientação pessoal, 1992.. 
Tabela 02: Esquema de análise de variância dos dados obtidos nos testes de laboratório e de campo, para cada experimento (com e sem calagem); etapas de avaliação ( 0 e 6 meses de armazenamento) e cultivos (águas e seca).

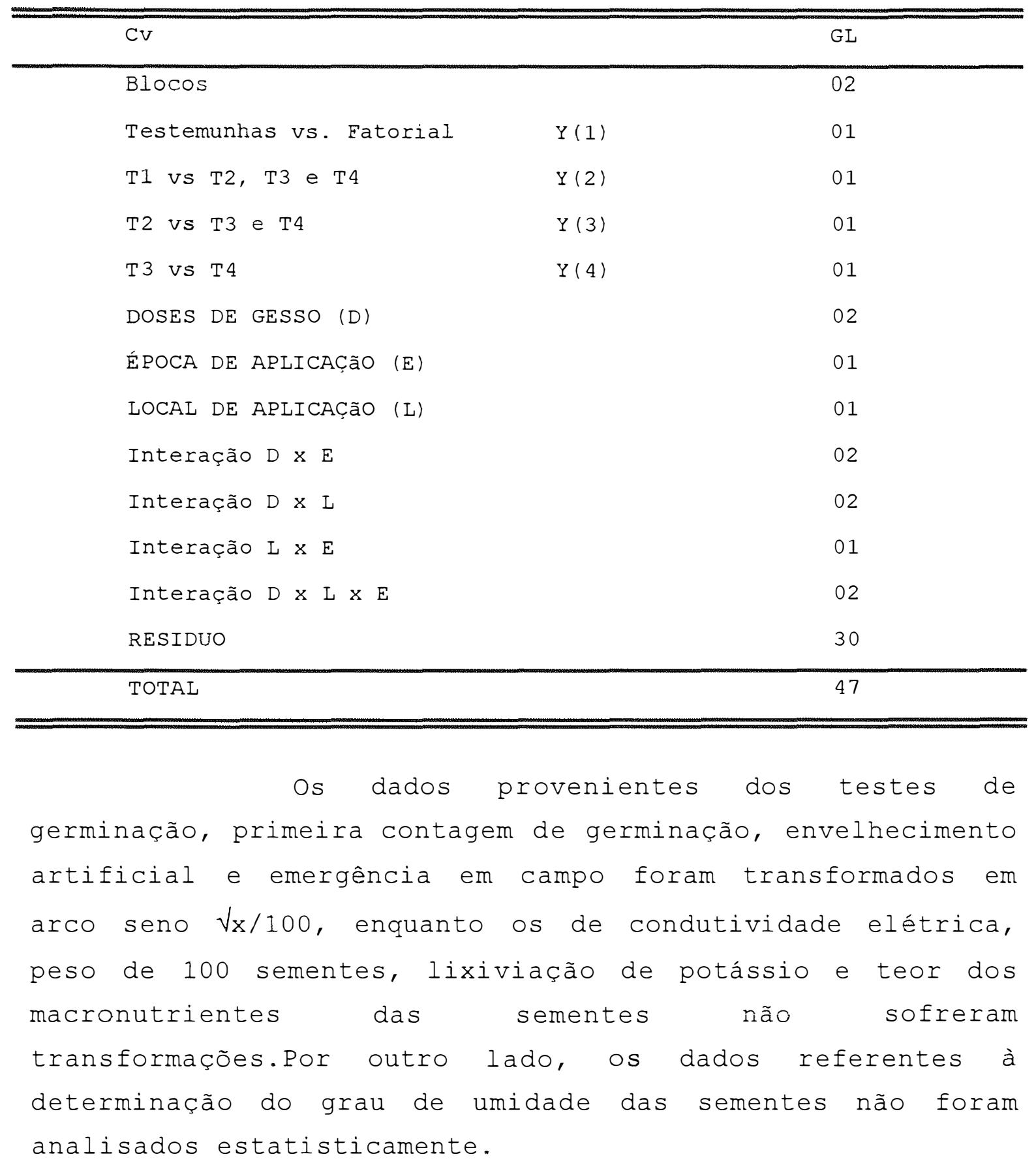




\title{
4. RESULTADOS E DISCUSSÃO
}

\subsection{Experimento I (área com calagem)}

\subsubsection{Cultivo das Águas}

\subsection{1.a. Primeira Etapa de Avaliação (após a colheita)}

\begin{abstract}
4.1.1.a.1. Teor de água
Os dados referentes ao grau de umidade das sementes para esta etapa de avaliação (Tabelas 04 e 05), permaneceram entre 6,6 à $7,1 \%$, que embora considerados baixos para a condução de alguns testes e não analisados estatisticamente, foram de um modo geral semelhantes para todos os tratamentos estudados, o que é importante na execução dos testes para avaliação da qualidade de semente, considerando-se que a uniformização da umidade das sementes é imprescindivel para a padronização das avaliações e obtenção de resultados consistentes, MATHEWS (1981), MARCOS FILHO et al. (1987) e LOEFELER et al. (1988).
\end{abstract}




\subsection{1.a.2. Peso de 100 sementes}

Observando-se os valores dos Quadrados

Médios obtido na análise de variância (Tabela 03), verificou-se diferença significativa quando se analisou a época de aplicaçào das doses de gesso agrícola, verificando-se peso superior das sementes quando se aplicou - gesso agrícola na semeadura (Tabela 05), discordando dos resultados obtidos por COX et al. (1982), GEUS (1973), PIVETTA (1978), FERREIRA et al.(1979) e SICHMANN et al. (1982), que verificaram que o cálcio aplicado no ínicio do florescimento resultou melhor desempenho da cultura, e dos resultados observados por BELL (1985) que não constatou diferença significativa na produção quanto a época de aplicação do nutriente.

\subsection{1.a.3. Germinação}

O exame da Tabela 03, permite verificar que embora tenha havido efeito significativo para doses de gesso agrícola, na qual se ajustou a regressão linear ( $Y$ = $1,160018842+0,042609493 X)(T a b e l a$ 05), não se observou pelo contraste Y1 diferença significativa de germinação entre as sementes provenientes dos tratamentos que receberam gesso agrícola com as sementes dos tratamentos que não receberam. Resultado este que se assemelha com o encontrado por Vieira (1986), onde foi verificado que aplicação corretiva dos diferentes produtos (calcário e gesso agrícola), associados ou não a aplicação dos mesmos em cobertura, não influenciaram essa característica. O mesmo não foi verificado por HALLOCK \& ALLISON (1980) e BELL (1985), que apesar de trabalharem com outros cultivares observaram relação positiva entre o conteúdo de cálcio no solo e a porcentagem de germinação. 


\subsection{1.a.4. Vigor}

Dentre os parâmetros que avaliaram 0 vigor nesta etapa de avaliação (Primeira contagem de germinação, envelhecimento acelerado, emergência em campo, condutividade elétrica e lixiviação de potássio), verificou-se somente diferenças significativas nos parâmetros emergência em campo e lixiviação de potássio (Tabela 03).

Para a emergência em campo houve diferença significativa na interação (local de aplicação $x$ época de aplicação), cujo desdobramento (Tabela 03.a), indicou que no local 2 (área total) a aplicação de gesso agrícola no florescimento proporcionou uma porcentagem de emergência superior a da aplicação na semeadura. Esses resultados concordam com os obtidos por COX et al. (1982), GEUS (1973), PIVETTA (1978) e EERREIRA et al. (1979) e SICHMANN et al. (1982), que verificaram que o cálcio aplicado no início do florescimento resultou em melhor desempenho da cultura.

Quanto à Iixiviaçào de potássio das sementes, houve diferença significativa para o contraste Y1, no qual se verifica que as sementes provenientes dos tratamentos que receberam gesso agrícola, liberaram maior quantidade de ions $K$ do que as obtidas dos tratamentos que não receberam (Tabela 04). O parâmetro lixiviação de potássio demonstrou também, diferença significativa quando se analisou as doses de gesso agrícola, ajustando-se a regressão linear $(Y=1245,624444+8,5670833 X)$ a qual indica, que quanto maior a dose de gesso agrícola, mais íons potássicos são liberados, revelando pior qualidade das sementes. Tal fato é de difícil compreensão, já que o esperado seria no mínimo um comportamento semelhante aos 
dos outros parâmetros em que não foi constatado diferenças significativas entre os tratamentos com e sem aplicação de gesso agrícola. Além do mais, presume-se que pela função que o cálcio desempenha nas membranas (MALAVOLTA, 1980), estas estariam mais integras, o que levaria a uma menor liberaçào de íons. Entretanto, deve-se resaltar que para a realização deste referído teste, foi utilizada a metodologia adaptada para sementes de soja, o que pode não ser a mais adequada para sementes de amendoim.

\subsection{1.a.5. Teor de macronutrientes nas sementes}

Entre os macronutrinentes analisados nas sementes (Tabela 06) apenas o nitrogênio(N) e o potássio(K) apresentaram diferenças significativas para os fatores analisados.

Para o nitrogênio tal diferença foi encontrada para o fator época de aplicação de gesso agrícola, onde se constatou que a aplicação do insumo na semeadura, proporcionou um teor de $\mathrm{N}$ na semente superior ao encontrado no florescimento (Tabela 08). Tal fato pode ser justificado pelas observações efetuadas por RODRIGUES et al.(1986), onde foi observado que o pico de transferência de $\mathrm{N}$ da planta para o fruto, no qual este se apresentou em maior concentração, procedeu-se aos 40 dias após a semeadura; desta maneira a aplicação de cálcio com o intuíto de aumentar a taxa de absorção de $\mathrm{N}$ (BELL et al., 1989), seria mais adequada na semeadura.

Quanto ao K, a diferença significativa foi

encontrada no contraste Y4, no qual se constatou que as sementes do tratamento que não recebeu enxofre elementar, revelou teor de $K$ na semente superior ao das sementes que receberam (Tabela 07). 


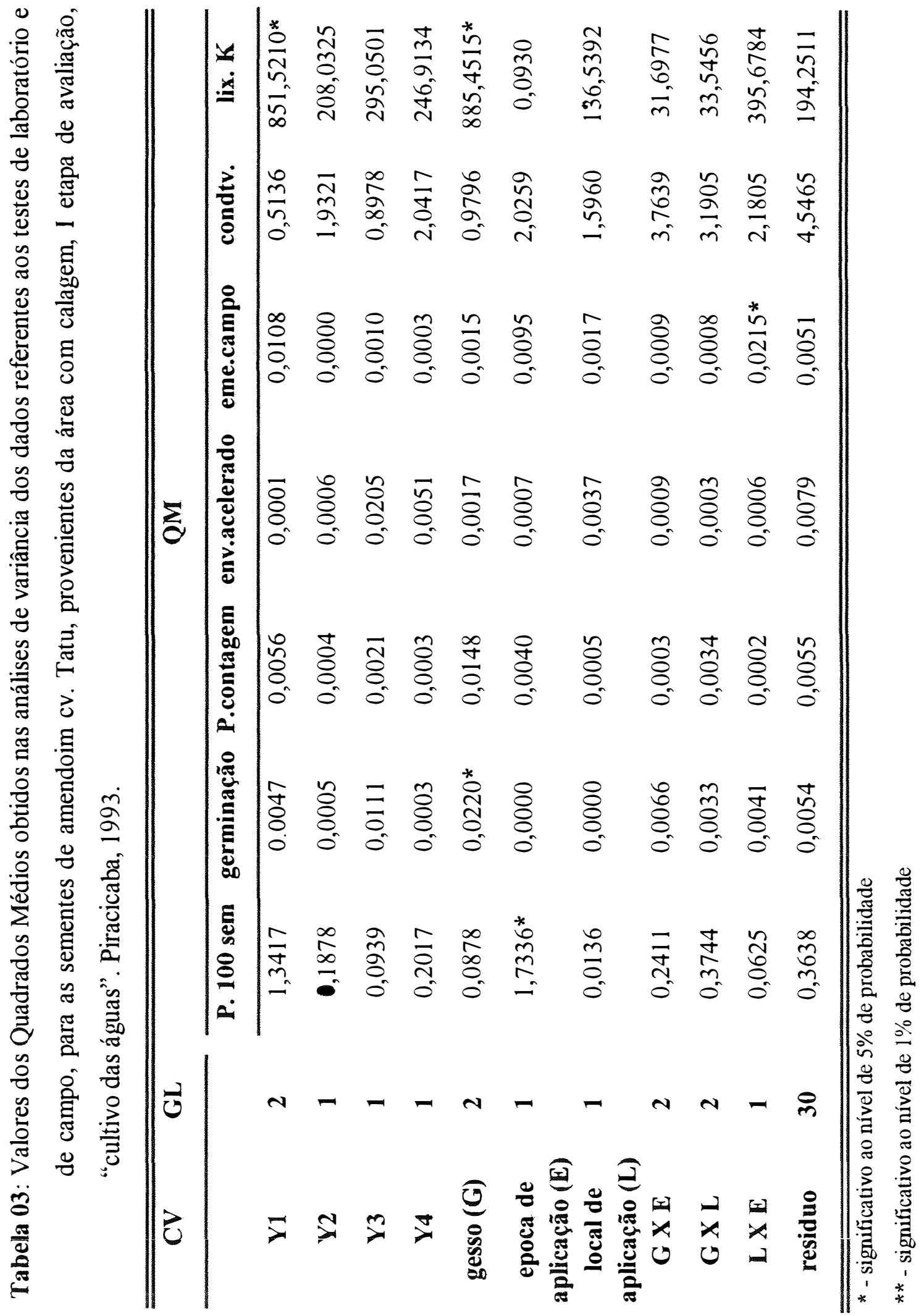


Tabela 03 a. :Desdobramento das interações significativas referentes a Tabela 03.

\begin{tabular}{|c|c|c|}
\hline \multicolumn{3}{|l|}{ PARÂMETROS } \\
\hline emergência em campo & $(\mathbf{L} \times \mathbf{E})^{*}$ & \\
\hline \multirow[b]{2}{*}{ Época de aplicação } & \multicolumn{2}{|c|}{ Local de aplicação } \\
\hline & localizado & área total \\
\hline semeadura & 86 & 81 \\
\hline florescimento & 85 & 87 \\
\hline
\end{tabular}




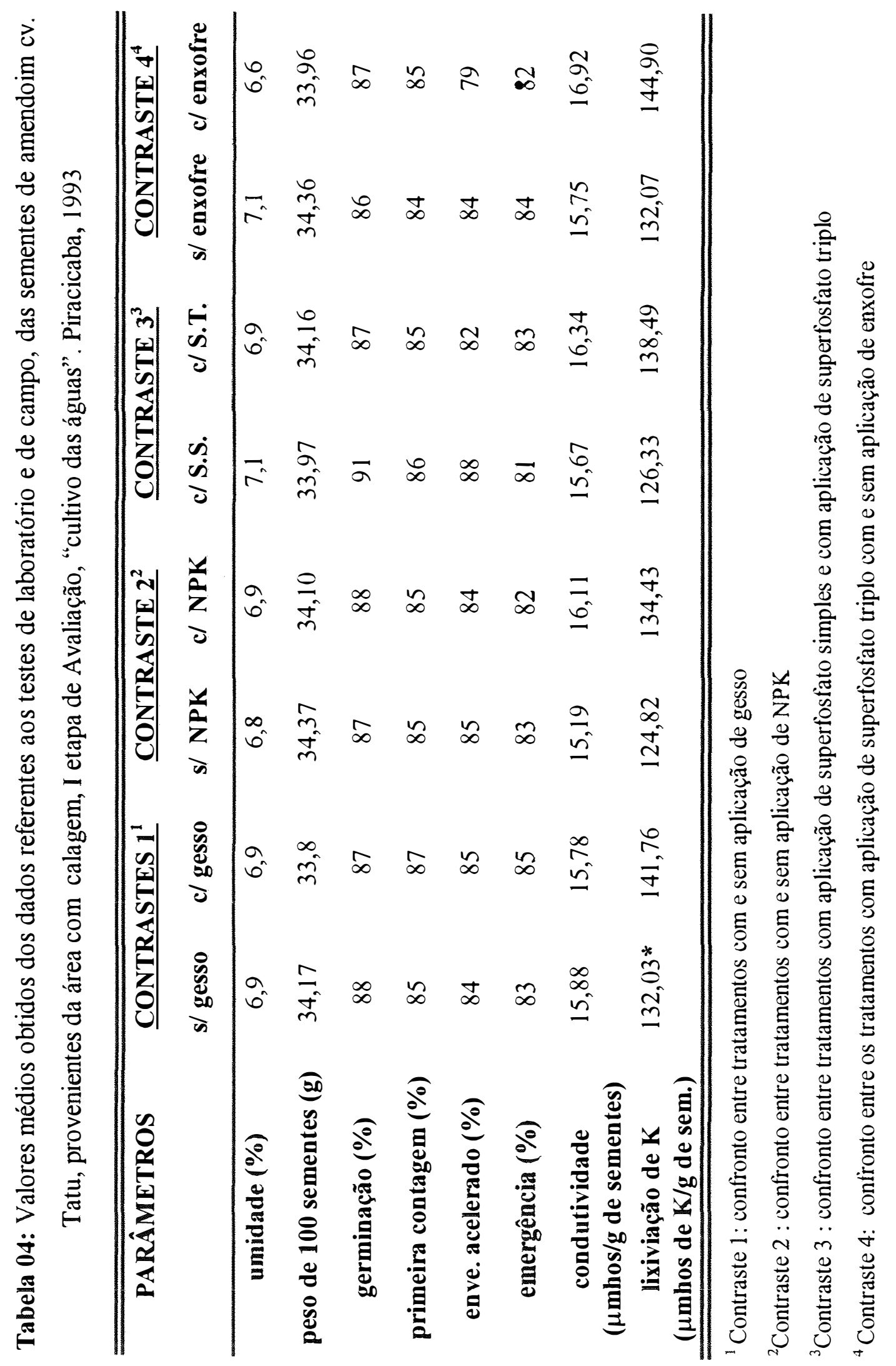




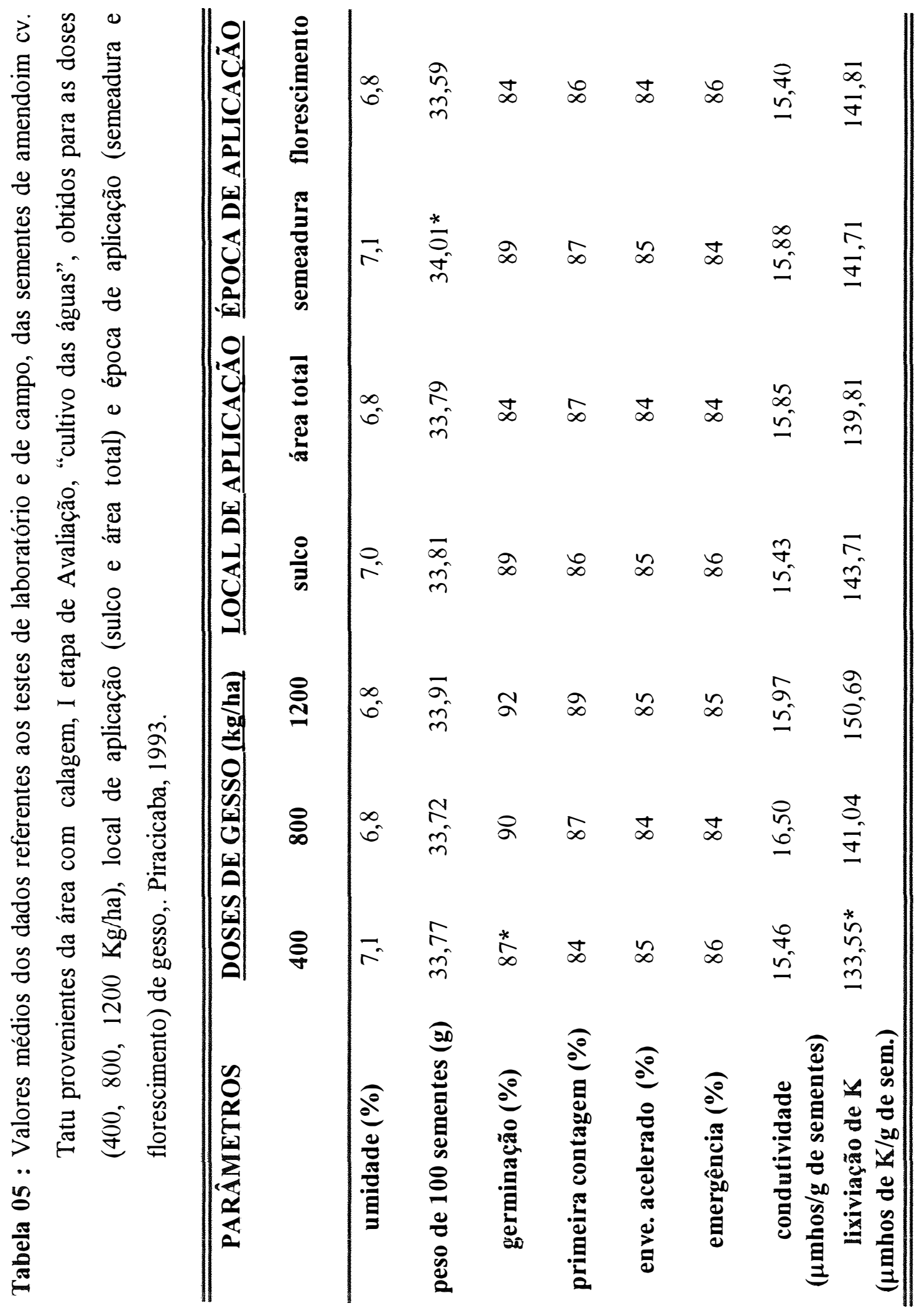




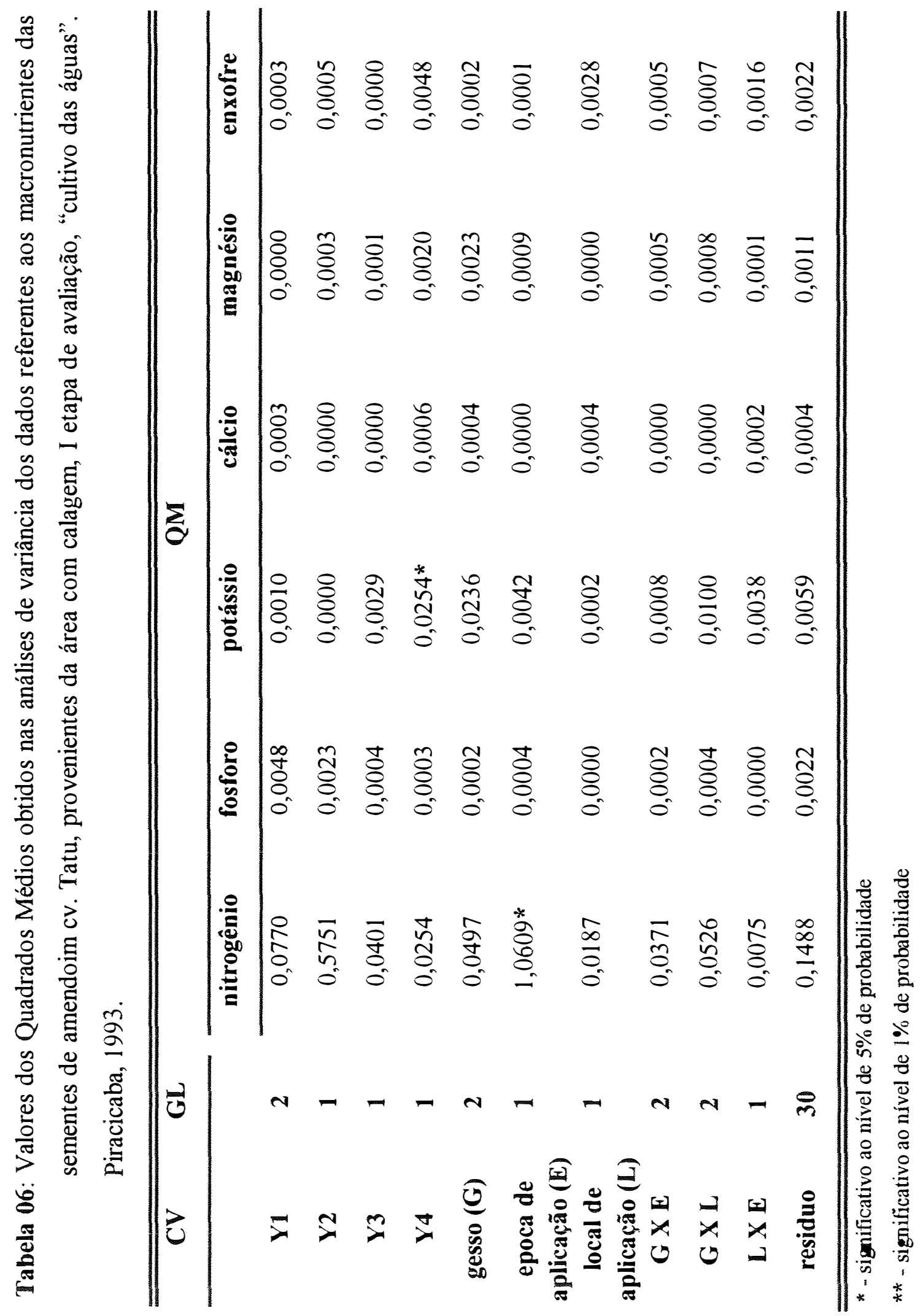




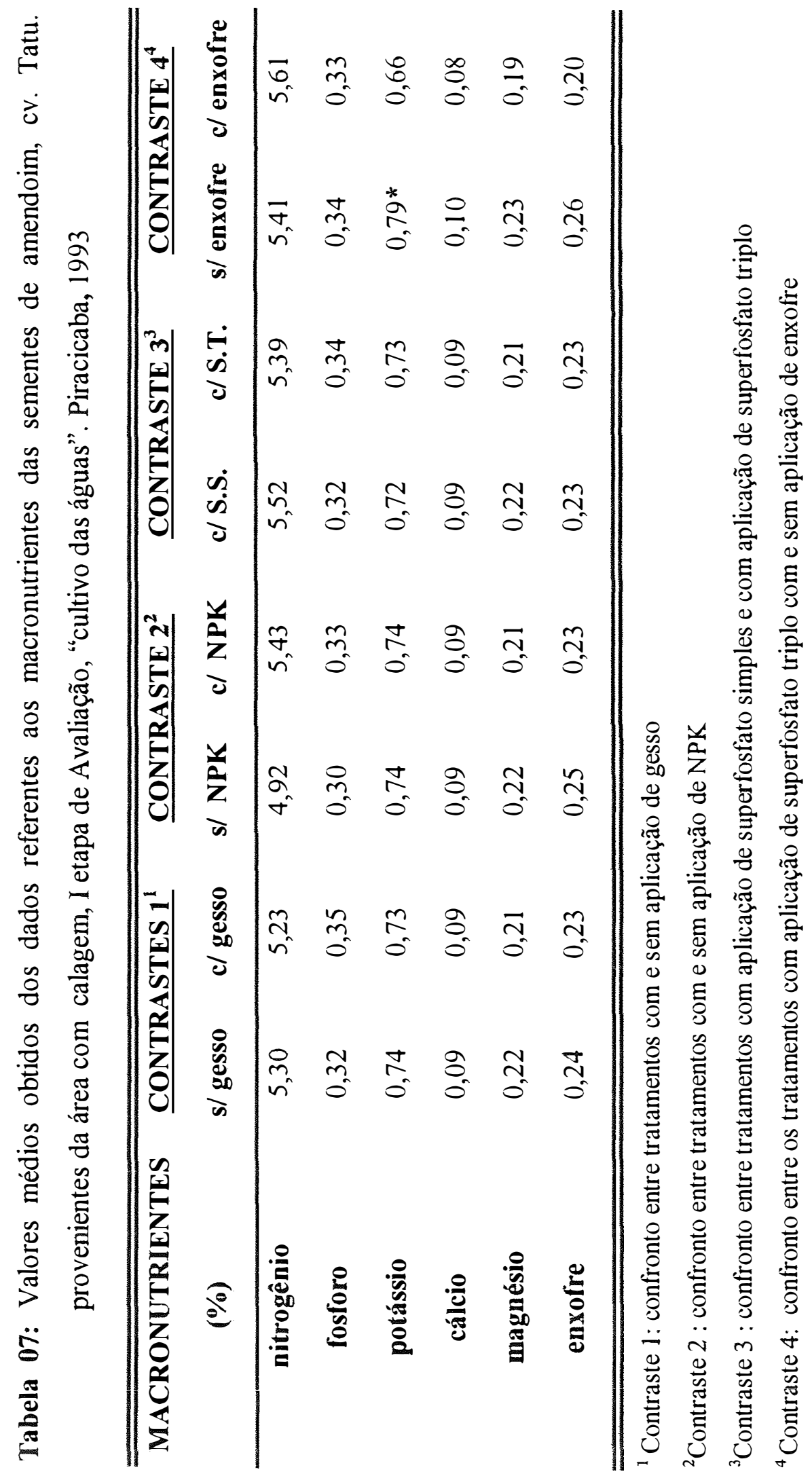




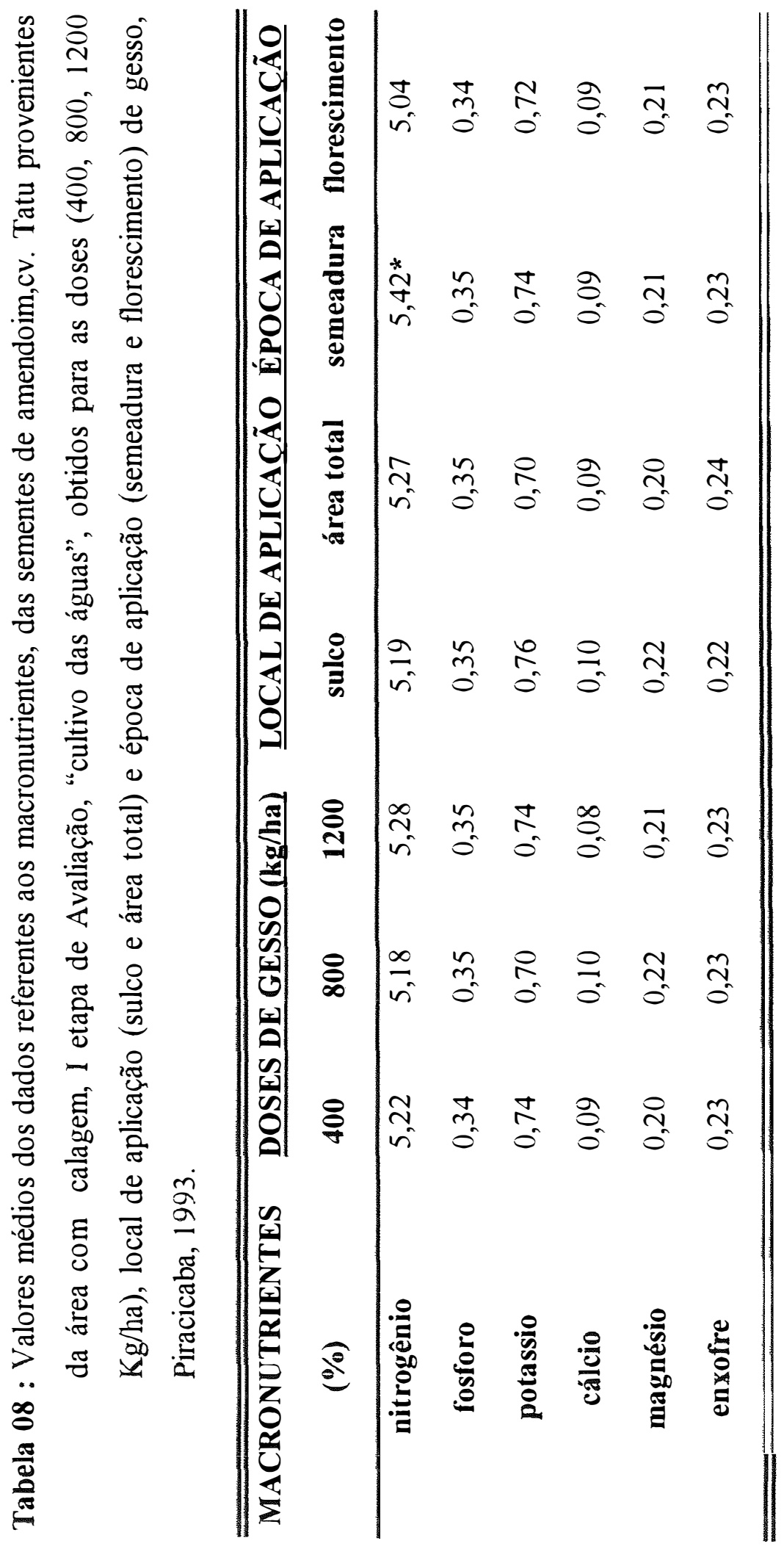




\subsection{1.b. Segunda Etapa de Avaliação (6 meses de armazenamento)}

\subsection{1.b.1 Teor de água}

O teor de água das sementes para esta etapa de análise (Tabela 10 e 11), permaneceu entre 7,3 a 7,6 \% indicando de uma maneira geral uniformização para todos os tratamentos estudados, o que é imprescendível para obtenção de resultados consistentes para a condução dos diversos testes para avaliação da qualidade das sementes realizados, como já citado no ítem 4.1.1.a.1.

Comparando-se o teor de água das sementes realizados nesta etapa, com os realizados na I etapa (após a colheita) (Tabela 04 e 05), pode-se considerar que praticamente não houve alteração do mesmo com o armazenamento, fato este evidenciado pela análise da Figura II (anexo) que nào revelou nenhuma alteração acentuada do ambiente de armazenamento, confirmando o observado por ROSSETO (1993) para o mesmo período de armazenamento.

\subsection{1.b.2. Germinação}

Para a germinação, observou-se diferenças significativas no contraste Y3 (Tabela 09), no qual se verifica que as sementes provenientes do tratamento que recebeu superfosfato simples (SS) apresentaram porcentagem de germinaçào superior as obtidas dos tratamentos que receberam superfosfato triplo (ST) (Tabela 10). Esse resultado discorda de NAKAGAWA et al. (1990), onde nào foi constatado diferenças significativas entre os diferentes adubos fosfatados em ambas localidades, mesmo após os 15 meses de armazenamento. 
Ao se comparar o teste de germinação das sementes realizado nesta etapa, com o realizado na etapa I de avaliação(após a colheita) (Tabelas 04 e05), verifica-se que de um modo geral as porcentagens de germinação encontradas para esta etapa apresentaram leve decréscimo.

\subsection{1.b.3. Vigor}

Dentre os parâmetros que avaliaram o vigor nesta etapa (primeira contagem de germinação, envelhecimento acelerado, condutividade elétrica e lixiviação de potássio), verificou-se somente diferenças significativas nos parâmetros primeira contagem e lixiviação de potássio (Tabela 09).

No teste primeira contagem de germinação, diferenças altamente significativas foram encontradas para - contraste Y3, no qual as sementes do tratamento que recebeu superfosfato simples (SS) foram superiores a dos tratamentos que receberam superfofato triplo (ST) (Tabela 10), mostrando concordância com os resultados obtidos na germinação .

Quanto a lixiviação de potássio das sementes, houve diferenças altamente significativas para o contraste Y2 (Tabela 10), no qual as sementes dos tratamentos com NPK, apresentaram quantidades de ions potássicos lixiviados superiores as do tratamento sem NPK, indicando sementes de melhor qualidade para o tratamento sem NPK. Resultado este discordante do encontrado por MAEDA et al. (1986), em que aos 6 meses de armazenamento não encontraram diferenças significativas entre sementes com NPK e sem NPK.

Para todos os parâmetros que avaliaram o vigor das sementes nesta etapa (Tabela 10 e 11), observou- 


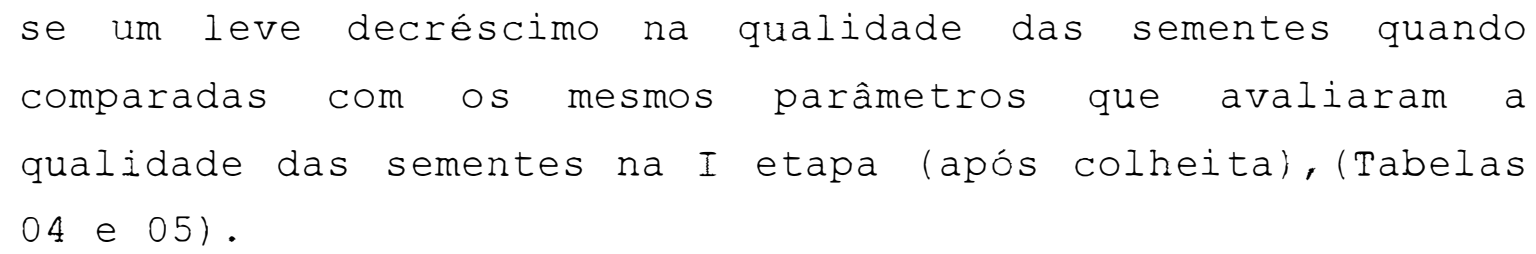




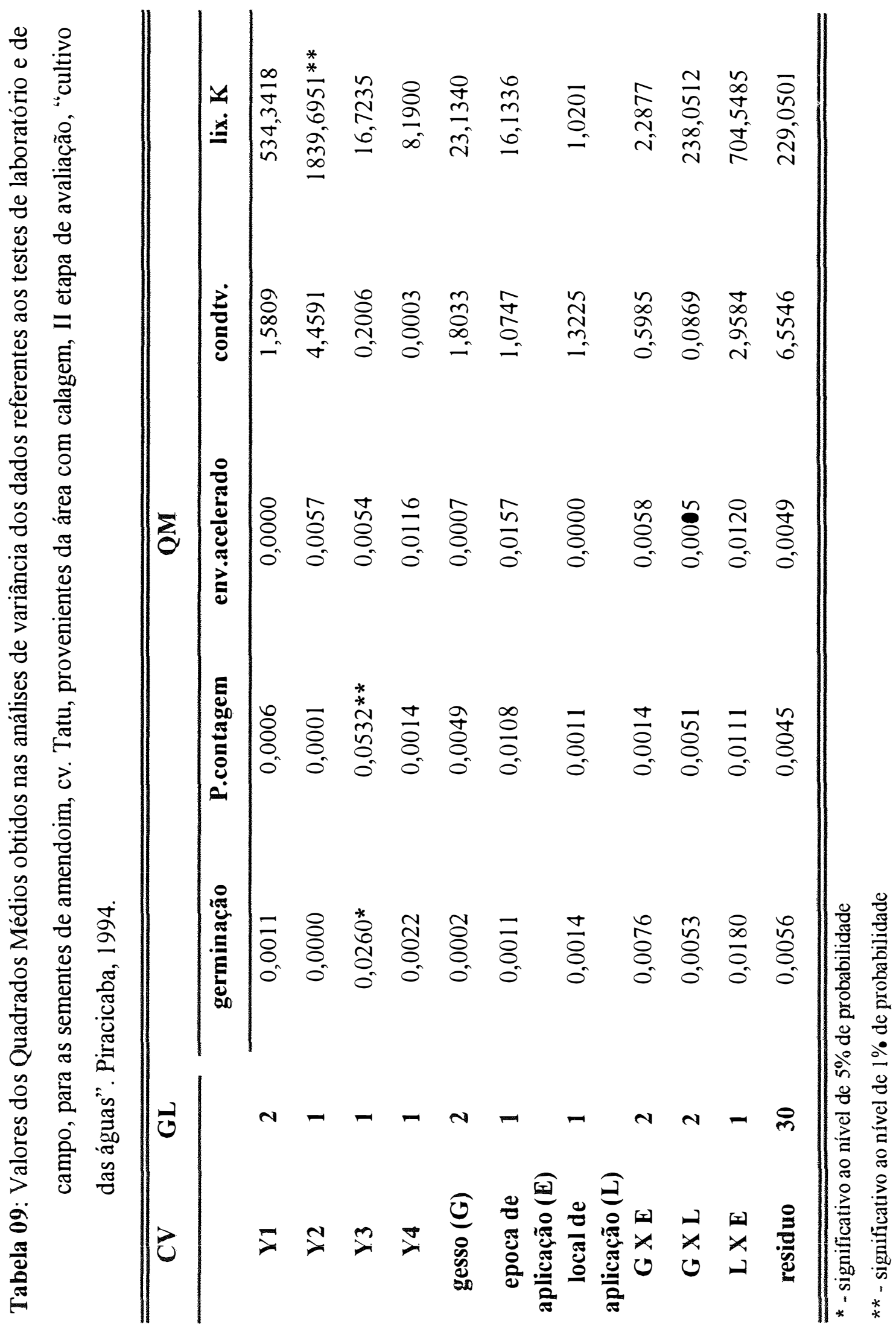




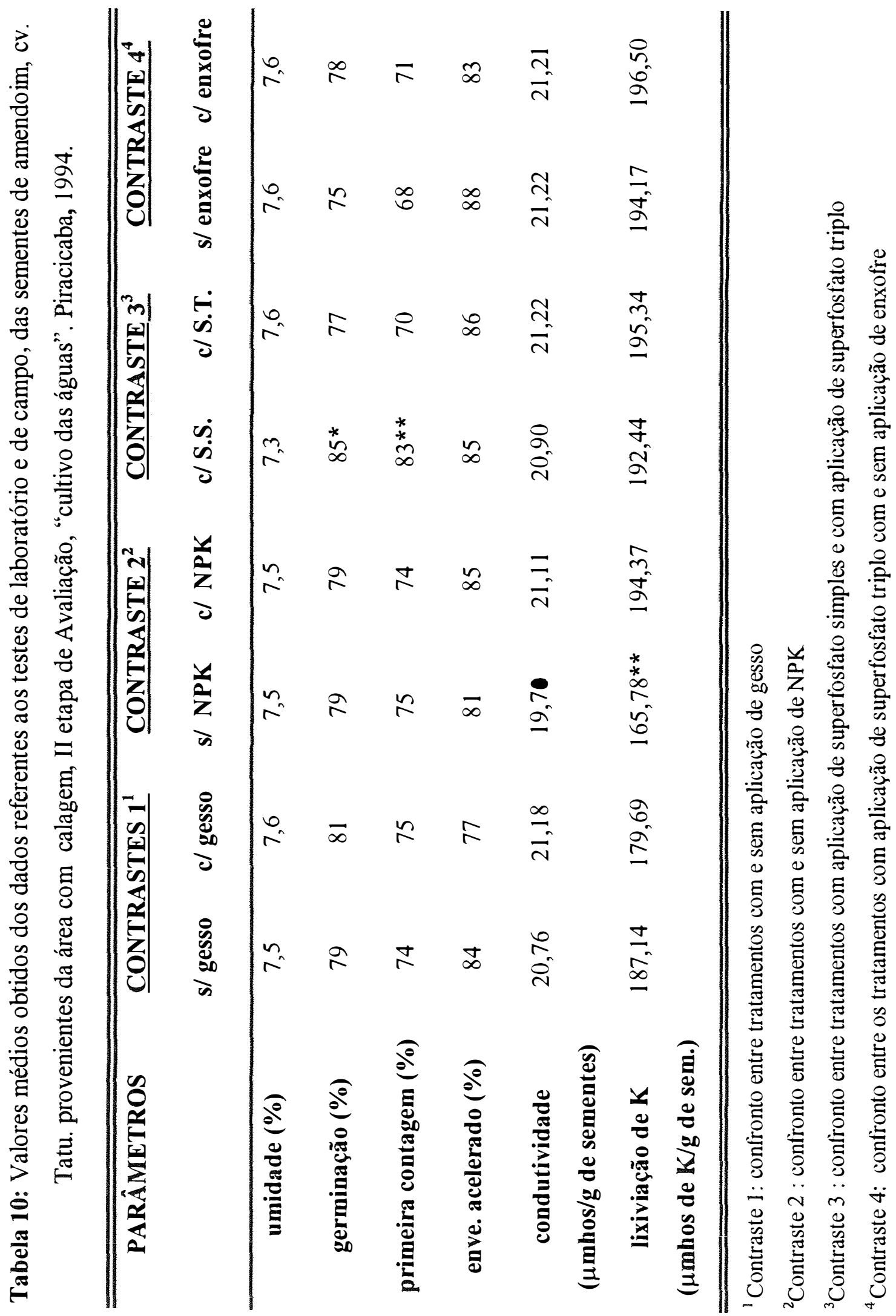




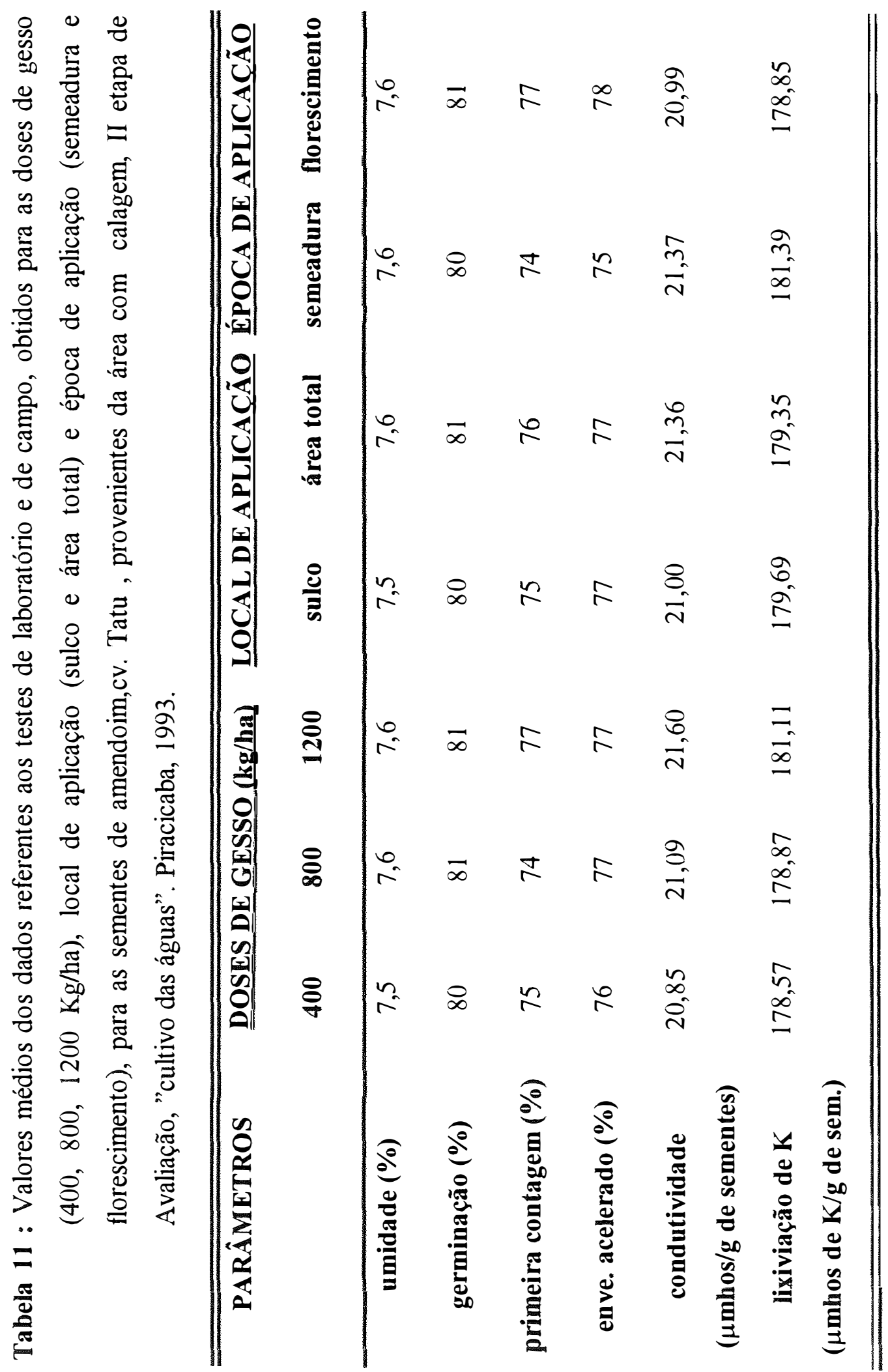




\subsubsection{Cultivo da Seca (efeito residual)}

\subsection{2.a. Primeira Etapa de Avaliação (após a colheita)}

\subsection{2.a.1. Teor de água}

O teor de água das sementes para esta etapa de análise, permaneceu entre 7,9 à 8,2 \% (Tabelas 13 e 14), onde pode-se verificar de maneira geral uma uniformização entre todos os tratamentos, fato este como já citado anteriormente, importante para obtenção de resultados consistentes dos diversos testes empregados para avaliação da qualidade das sementes.

\subsection{2.a.2. Peso de 100 sementes}

Para este parâmetro, nesta etapa de avaliação foi verificado que não houve diferença significativa para os diversos fatores análisados (Tabela 12). Não sendo constatado assim, influência resídual do Ca e nem dos adubos empregados. Fato este não observado por NAKAGAWA et al.(1990) no município de Julio de Mesquita, onde o efeito residual do Ca foi benéfico para o aumento do peso de 100 sementes.

\section{Entretanto, ao se comparar estes valores} absolutos com os valores na época das águas, pode-se verificar que o peso de 100 sementes obtidos neste cultivo (efeito residual) (Tabelas 13 e 14), apresentou-se inferior ao observado no cultivo das águas (efeito imediato)(Tabelas 04 e 05). Resultado semelhante a este, foi encontrado por NAKAGAWA et al. (1990) no experimento instalado no município de Marília. 


\subsection{2.a.3. Germinação}

Observando-se os valores dos Quadrados médios obtidos na análise de variância da Tabela 12 , não foi verificado benefício algum do efeito residual do gesso agrícola aplicado. Fato este não observado por NAKAGAWA et al. (1990) nos dois Municípios em que foram realizados os experimetos, onde foi constatado o efeito benéfico do $\mathrm{Ca}$ residual.

Entretanto, ao se analisar a interação (doses de gesso agrícola x época de aplicação) (Tabela 12.a) observa-se diferenças significativas na época 1 (semeadura) em que as doses de gesso agrícola se ajustam a seguinte curva de regressão quadrática ( $Y=1,534151641$ $0,2237928000 x+0,059328922 x^{2}$ )

Ao se comparar a porcentagem de germinação em valores absolutos, entre este cultivo e o cultivo das águas, observa-se de uma maneira geral a superioridade deste cultivo para todos os fatores analisados.

\subsection{2.a.4.Vigor}

Para os parâmetros que avaliaram o vigor nesta etapa de avaliação, observa-se pela análise dos quadrados médios (Tabela 12), que o teste de envelhecimento acelerado das sementes e emergência de plântulas em campo foram os únicos que apresentaram diferenças significativas. Para $\circ$ envelhecimento acelerado diferenças foram encontradas quando se análisou o contraste Yl (Tabela 13), no qual se constatou que as sementes dos tratamentos que receberam gesso agrícola apresentaram-se superiores as dos tratamentos que não receberam. NAKAGAWA et al. (1990), verificaram também $\bigcirc$ mesmo efeito do $\mathrm{Ca}$ residual na qualidade das sementes, nos dois Municipios estudados, 
sendo que em Marilia apenas o teste primeira contagem de germinação confirmou tal efeito.

Quanto a emergência das plântulas em campo, diferenças foram encontradas quando se analisou a interação (gesso agrícola x local de aplicação) (Tabela 12.a), verificou-se que para as doses de gesso agrícola aplicados de forma localizada (sulco) e na área total se ajustaram as seguintes regressões lineares: ( $Y=\quad 1,219041274$ $0,0535408458 \mathrm{x}) ; \quad(\mathrm{Y}=1,002865538+0,052630568 \mathrm{x})$, respectivamente, revelando efeitos opostos a medida que se aumenta a dose de gesso agrícola. Diferença significativa foi encontrada também, para a interação llocal x época de aplicação), onde pelo desdobramento da interação (Tabela 12.a), verificou-se diferença significativa apenas ao se analisar à aplicação de gesso agrícola de forma localizada (sulco), no qual a aplicação do insumo no florescimento apresentou maior porcentagem de emergência de plântulas em campo se comparada a aplicação do mesmo na semeadura. Mesmo resultado foi observado na época das águas só que diferindo quanto ao local de aplicação.

Ao se comparar, todos os parâmetros utilizados nesta etapa para avaliar o vigor das sementes com os mesmos parâmetros utilizados no cultivo das águas, constatou-se que estes se revelaram superiores, exceção feita à emergência das plântulas em campo.

\subsection{2.a.5. Teor de macronutrientes nas sementes.}

Os macronutientes da sementes que apresentaram diferenças significativas foram o fosforo (P), magnésio (Mg) e o enxofre (S) (Tabela 15).

O teor de $\mathrm{P}$ nas sementes apresentou diferença significativa para o contraste $Y 1$, no qual as 
sementes dos tratamentos que não receberam gesso agrícola apresentaram teor de $P$ inferior as dos tratamentos que receberam (Tabela 16), resultado este que pode ser observado no trabalho realizado por BELL (1989), onde foi constatado que a taxa de absorção de $\mathrm{P}$, assim como a de $\mathrm{N}$, aumentaram com o aumento da disponibilidade de Ca no solo.

Para o teor do nutriente Mg das sementes, a diferença foi encontrada quando se analisou o contraste Y3, no qual pode-se constatar que as sementes provenientes do tratamento com SS revelou menor porcentagem do nutriente quando comparado com as obtidas dos tratamentos que receberam O ST (Tabela 16). Diferença significativa para este nutriente, também, foi verificada para o fator local de aplicação de gesso agrícola, onde observou-se que a aplicação do gesso agrícola no sulco proporcionou maior porcentagem de $\mathrm{Mg}$ na semente em relação a aplicação do insumo na área total.

O enxofre, como o Mg apresentou diferença significativa quando se analisou o tratamento com $\mathrm{SS}$ em relação ao $\mathrm{ST}$, apresentando maior porcentagem de $S$ na semente para os tratamentos com ST (Tabela16).

De uma maneira geral, ao se comparar em valores absolutos os teores dos macronutientes encontrados nas sementes do cultivo das águas (Tabela 07 e 08), com os encontrados nas sementes do cultivo da seca, verifica-se uma leve superioridade dos nutrientes N, P, Mg, S para o cultivo das águas, ao passo que o $K$ manteve-se semelhantes nos dois cultivos e o cálcio ca encontrado no cultivo das águas foi 3 vezes superior ao encontrado no cultivo da seca. 


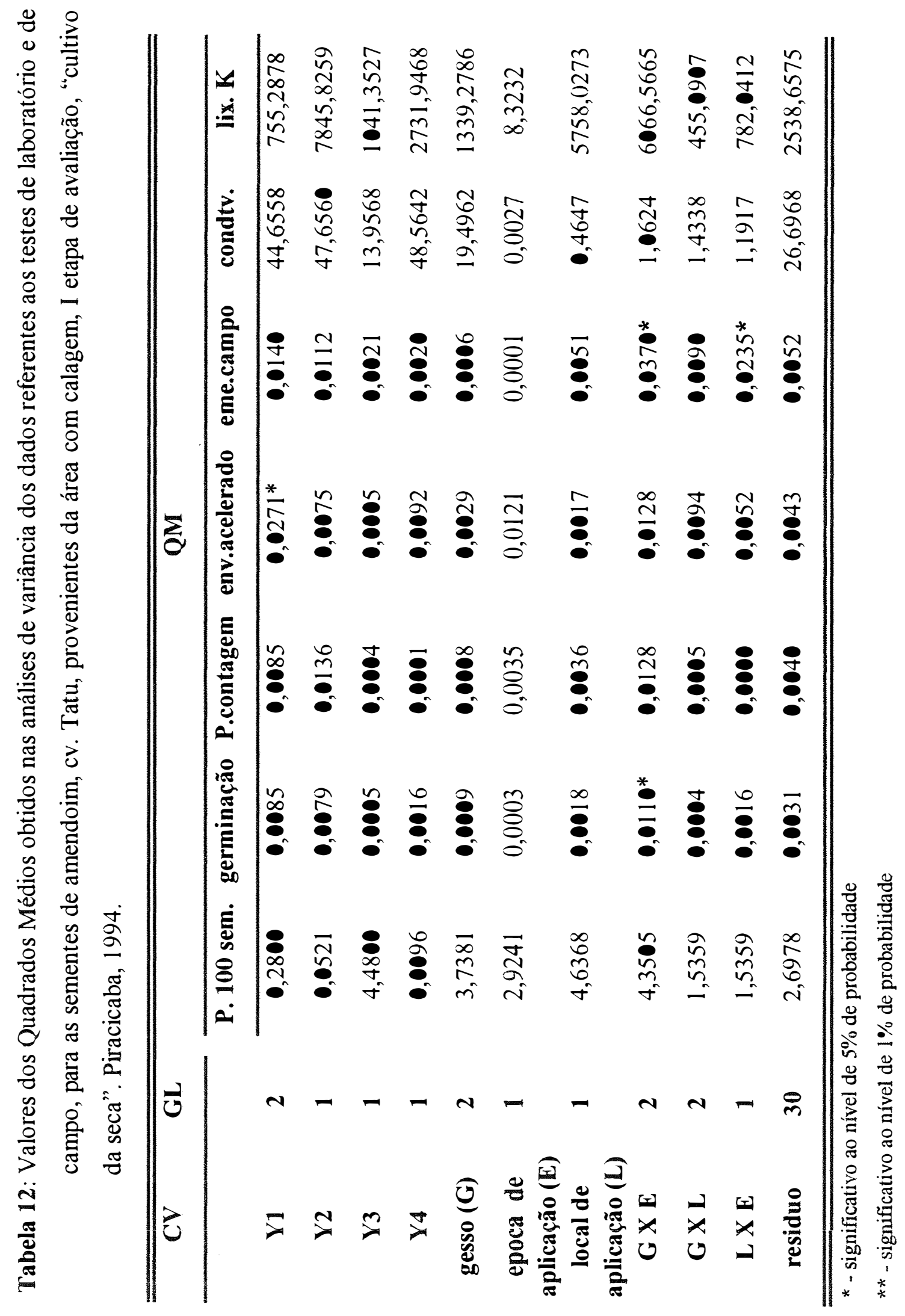


Tabela 12 a. :Desdobramento das interações significativas referentes a Tabela 12.

\begin{tabular}{|c|c|c|}
\hline \multicolumn{3}{|l|}{$\overline{\text { PARÂMETROS }}$} \\
\hline \multirow[t]{2}{*}{ germinação } & \multicolumn{2}{|l|}{$(G \times E)^{*}$} \\
\hline & \multicolumn{2}{|c|}{ Época de aplicação } \\
\hline Doses de gesso agrícola & semeadura & florescimento \\
\hline G 1 & 96 & 96 \\
\hline G 2 & 94 & 97 \\
\hline G 3 & 97 & 95 \\
\hline \multicolumn{3}{|c|}{ * } \\
\hline \multirow[t]{2}{*}{ emergência em campo } & \multicolumn{2}{|l|}{$(G \times E)^{*}$} \\
\hline & \multicolumn{2}{|c|}{ Local de aplicação } \\
\hline Doses de gesso agrícola & localizado & área total \\
\hline G 1 & 85 & 75 \\
\hline G 2 & 79 & 82 \\
\hline \multirow[t]{2}{*}{ G 3} & 76 & 83 \\
\hline & * & * \\
\hline \multirow[t]{2}{*}{ emergência em campo } & \multicolumn{2}{|l|}{$(L X E)^{*}$} \\
\hline & \multicolumn{2}{|c|}{ Local de aplicação } \\
\hline Época de aplicação & localizado & área total \\
\hline semeadura & 77 & 80 \\
\hline florescimento & 83 & 79 \\
\hline
\end{tabular}




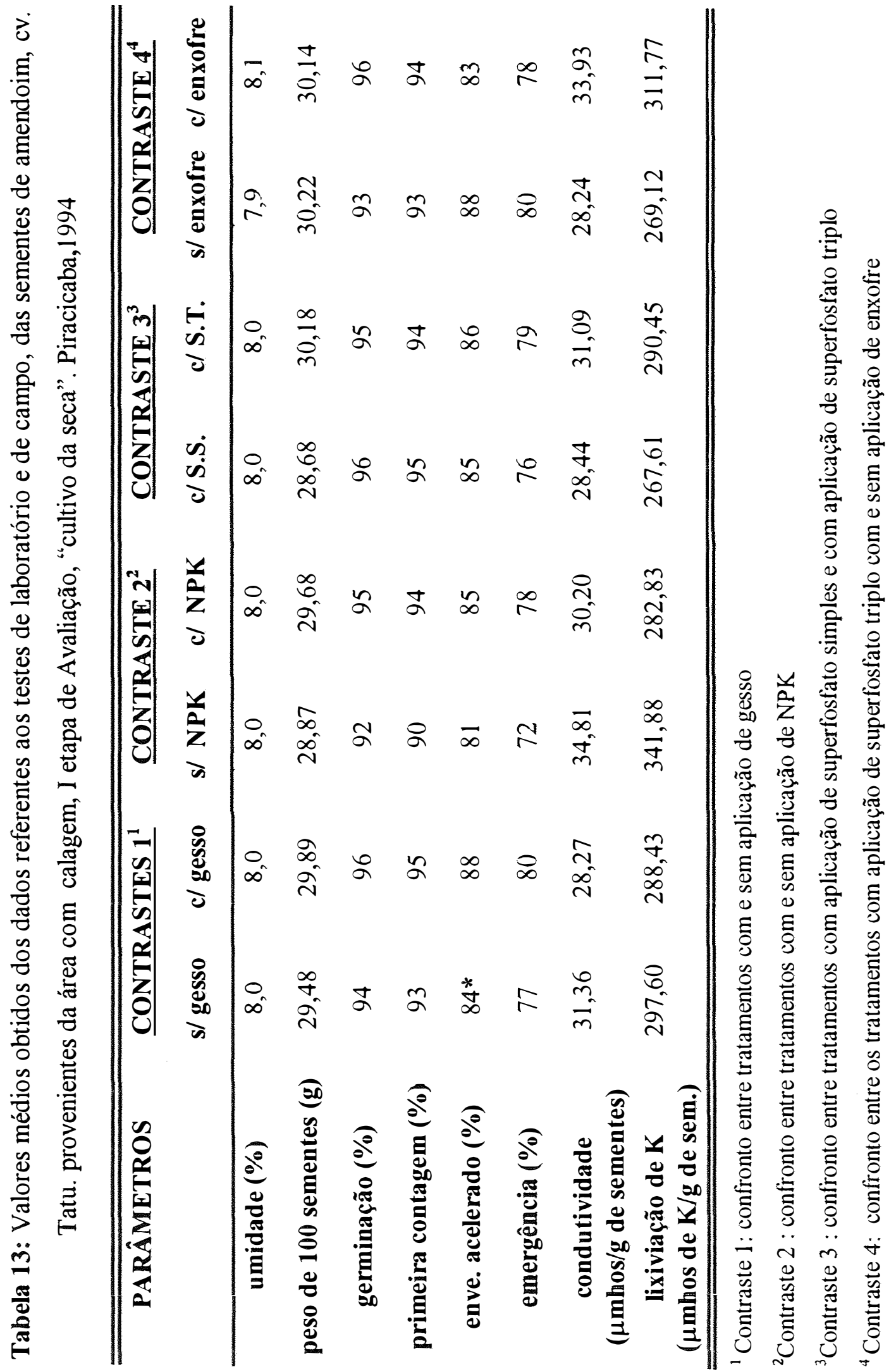




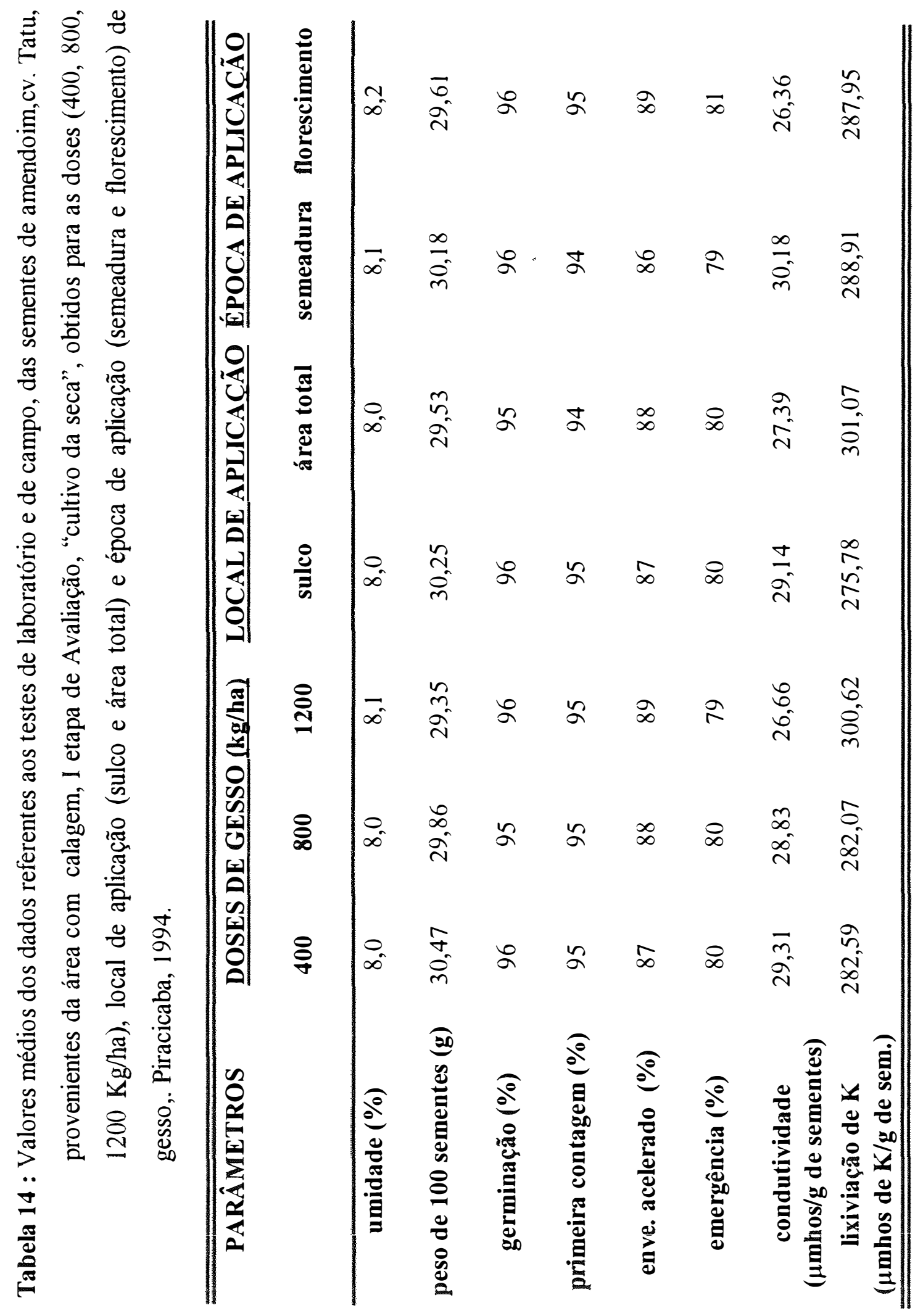




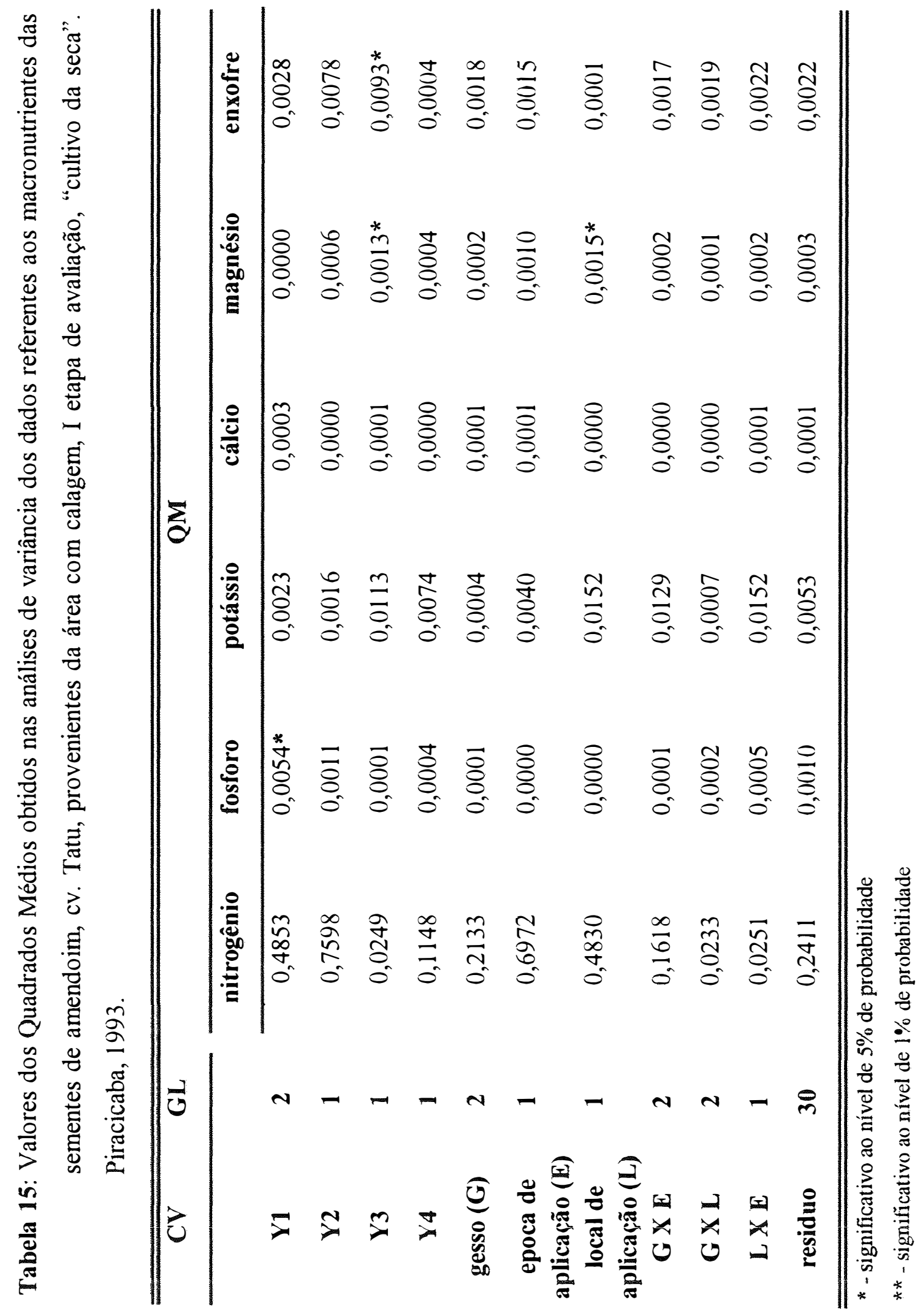




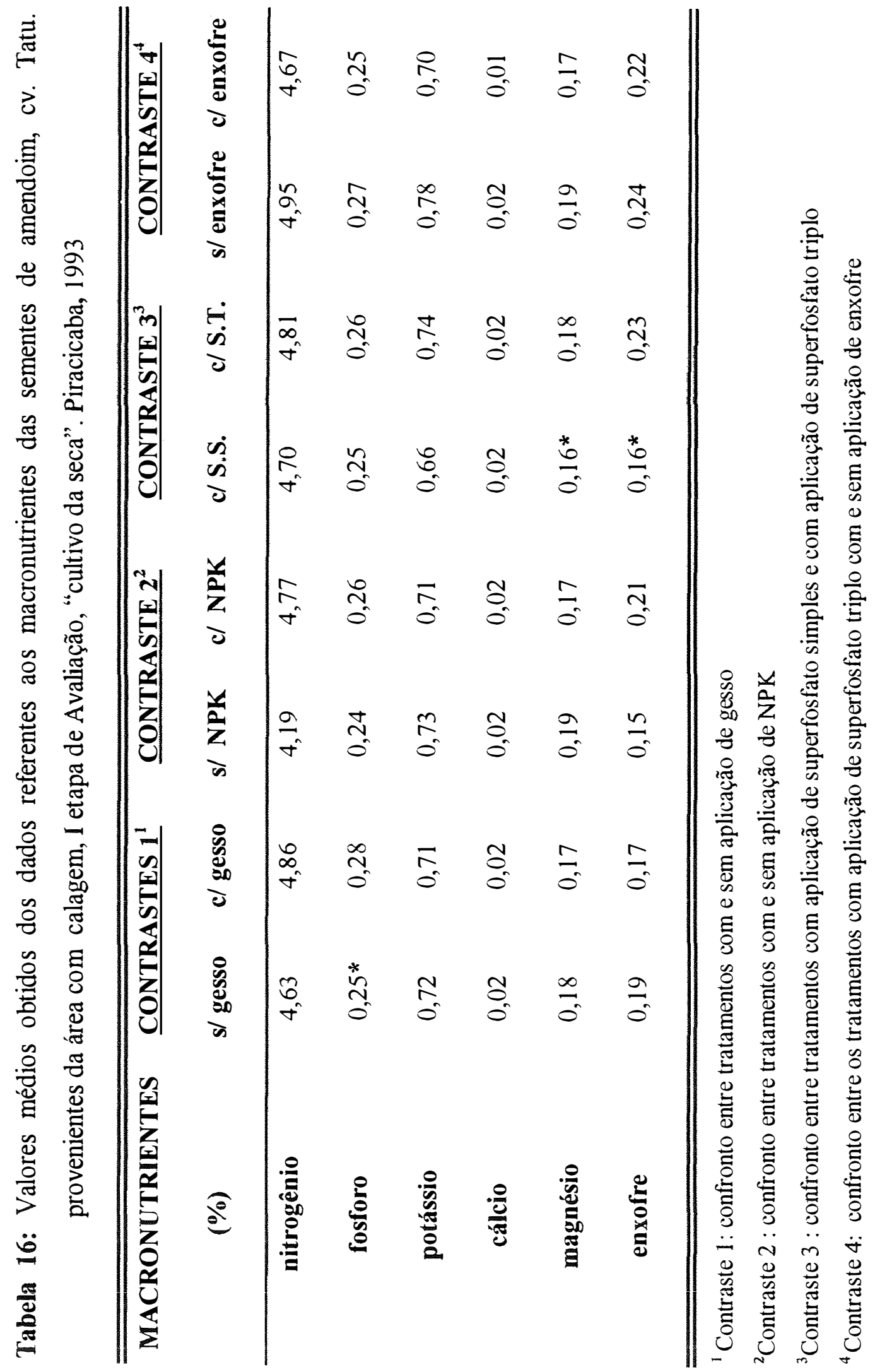




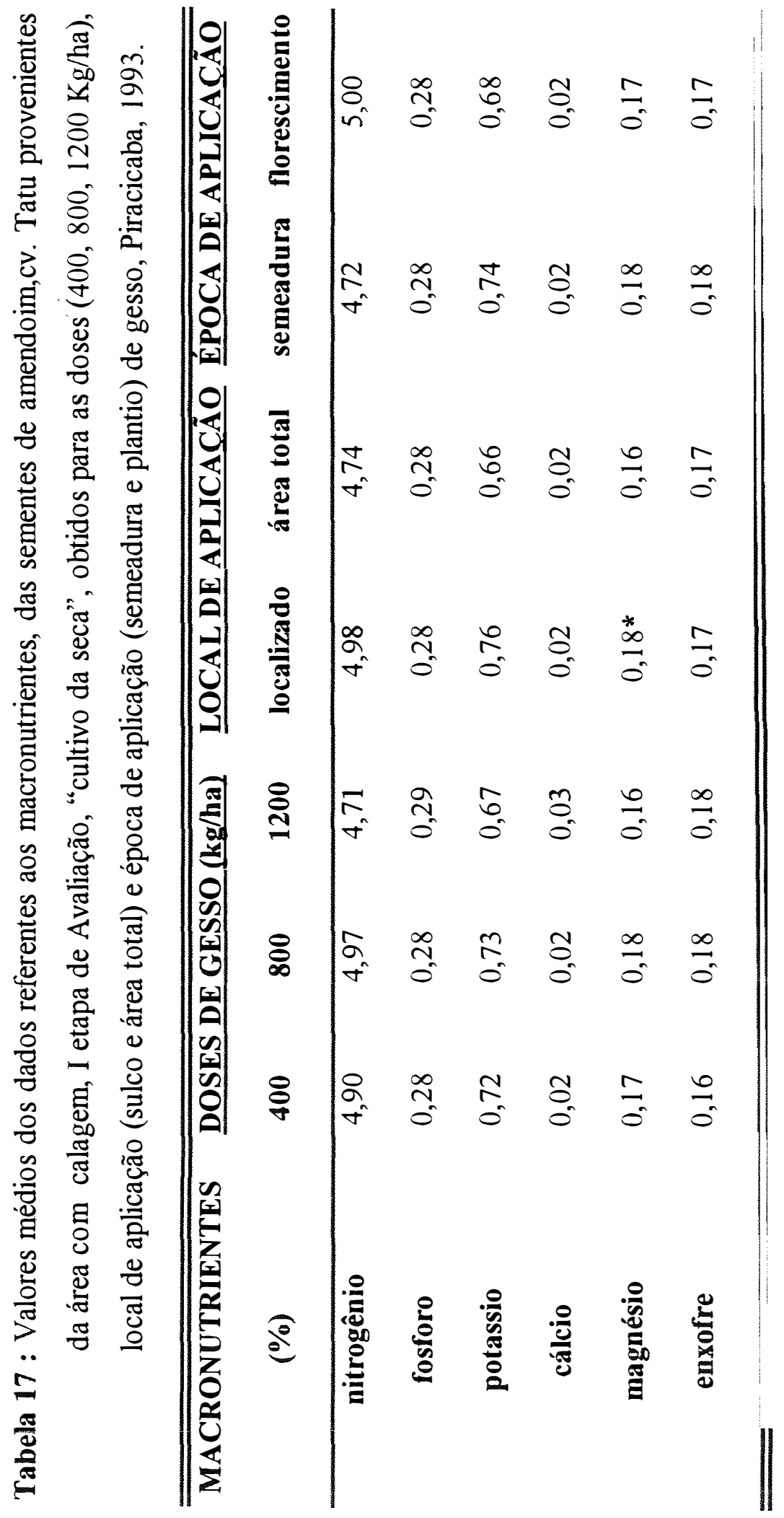




\subsection{2.b. Segunda Etapa de Avaliação ( 6 meses de armazenamento)}

\subsection{2.b.1. Teor de água}

O teor de água das sementes para esta etapa de análise, permaneceu entre 5,5 e 6,5\% (Tabelas 19 e 20), verificando-se de uma maneira geral uniformização dos dados obtidos entre os tratamentos e um teor adequado para armazenagem.

Comparando-se o teor de água das sementes no inicio do armazenamento (I Etapa de Avaliação) (Tabelas 13 e 14), com os obtidos nesta etapa de avaliação, constatou-se que houve um pequeno decréscimo nos valores obtidos, o que pode ser explicado pela Figura IV (anexo), onde, verifica-se um ambiente menos úmido que o encontrado para o armazenamento do cultivo das águas Figura III (anexo). Ambiente este no qual as sementes por estarem com umidade mais elevada no inicio do armazenamento fez com que as mesmas entrassem em equilibrio higroscópico com a umidade relativa do ambiente, assumindo menores teores de água.

\subsection{2.b.2. Germinação}

Pela análise dos quadrados médios verificados na Tabela 18, constata-se que não houve nenhuma diferença significativa entre os fatores análisados. Entretanto, ao se analisar os valores absolutos encontrados nesta etapa de avaliação (Tabela 19 e 20) com os encontrados na I etapa de avaliação (após a colheita) (Tabela 13 e 14), observar-se um decréscimo das porcentagens nesta etapa de avaliação. 


\subsection{2.b.3. Vigor}

Entre os testes utilizados para avaliar o vigor das sementes nesta etapa (primeira contagem de germinação, envelhecimento acelerado, condutividade elétrica e lixiviação de potássiol, constatou-se diferenças significativas pra os três últimos parâmetros(Tabela 18). O teste envelhecimento acelerado revelou que a época de aplicação do gesso agrícola mais eficaz foi a do florescimento (Tabela 20).

Para 0 teste de condutividade elétrica observa-se que as sementes provenientes do tratamento que não recebeu enxofre apresentaram menor lixiviação de íons do que as dos tratamentos que receberam, indicando melhor qualidade das sementes (Tabela 19).

Por outro lado, a lixiviação de potássio indicou que a aplicação do gesso agrícola é melhor na forma localizada (no sulco) (Tabela 20). 


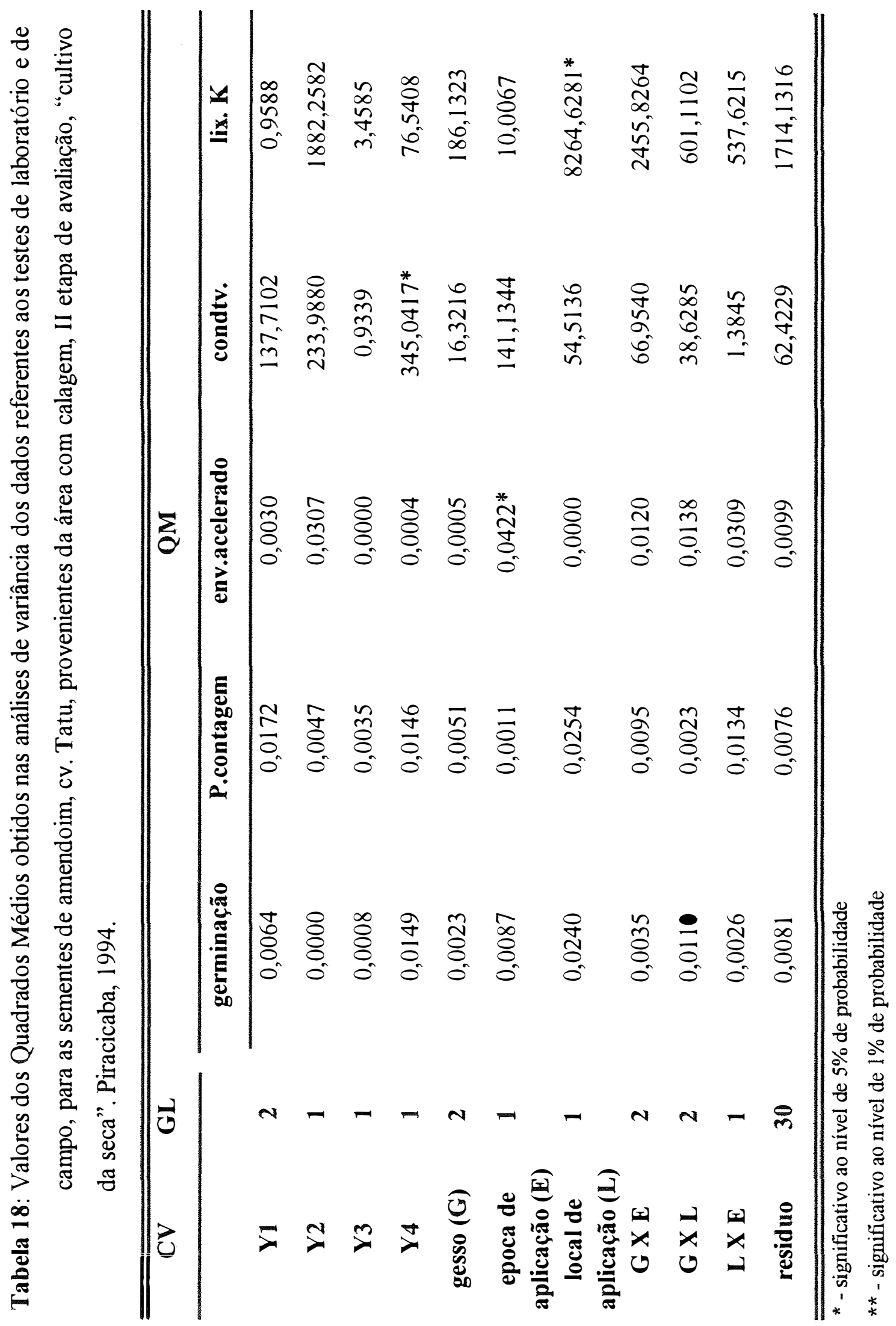




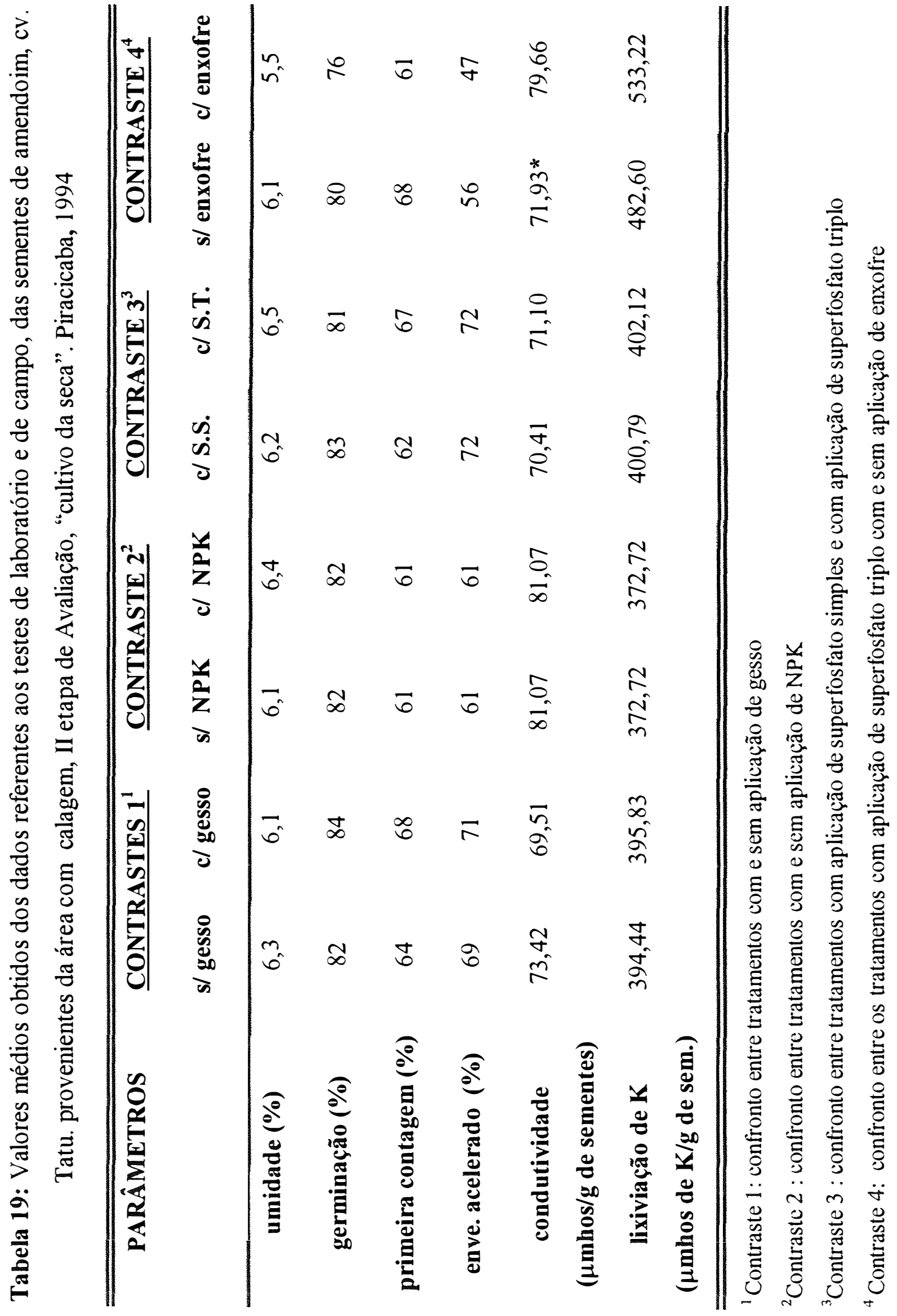




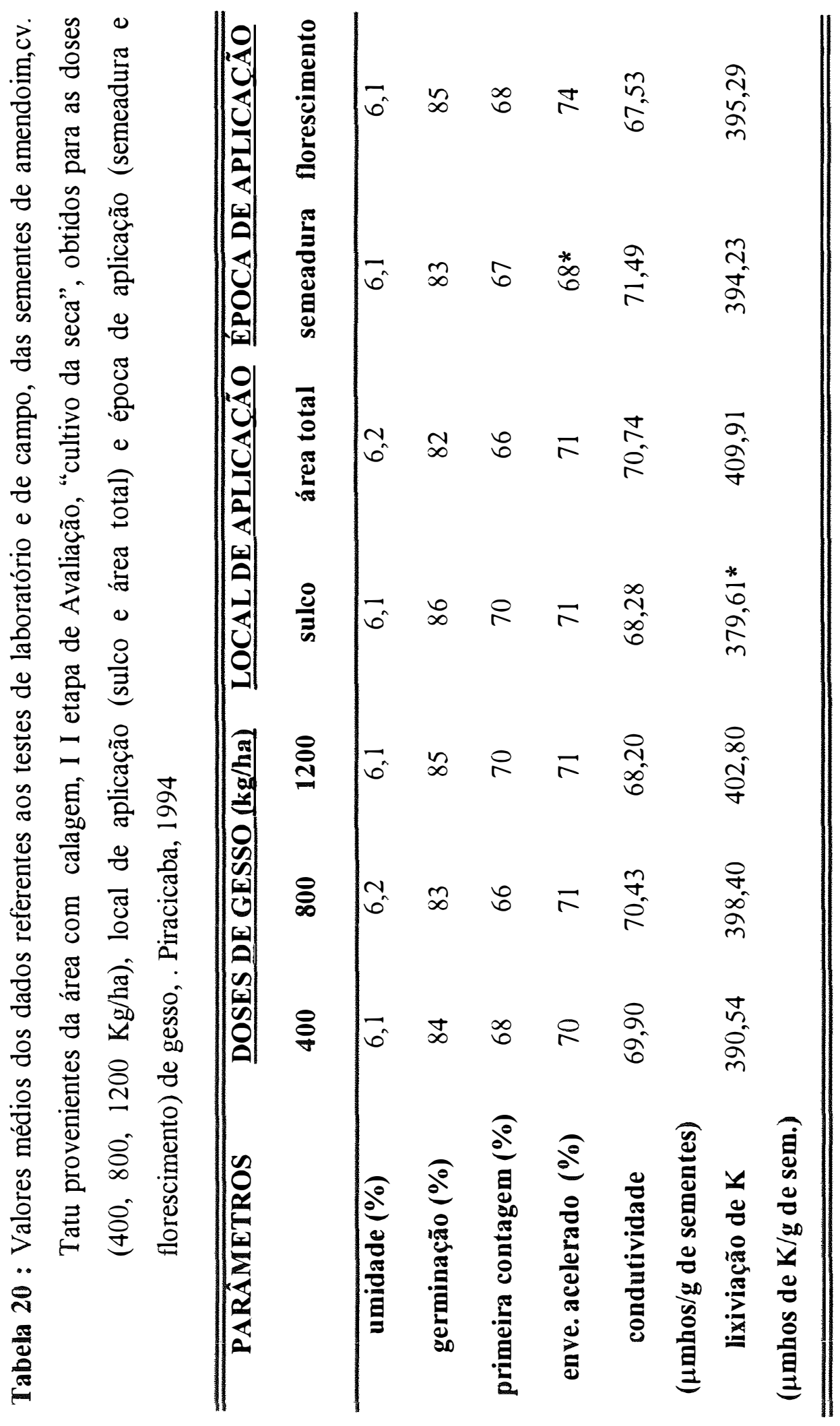




\title{
4.2.1. Considerações Gerais I.
}

\begin{abstract}
Para ęste experimento (área com calagem), observou-se que tanto para o "cultivo das águas" como para - "cultivo da seca" a simples aplicação do gesso agrícola não interferiu na qualidade das sementes em ambas as etapas
\end{abstract} de avaliação.

Quanto aos outros fatores analisados (épocas e modos de aplicação de gesso agrícola), nemhuma afirmação conclusiva pode ser constatada, pois, verificouse que não houve concordância entre a maioria dos parâmetros de qualidade de sementes utilizados.

Em valores absolutos, observou-se que o "cultivo da seca" (efeito residual) mostrou-se superior ao "cultivo das águas" para os parâmetros germinação e vigor (exceção feita à emergência das plântulas em campo).

A superioridade do "cultivo da seca"em termos de qualidade de sementes obtidas em relação ao "cultivo das águas", pode ser explicado pela análise das Figuras I e II (anexos), onde pôde-se constatar a influência de fatores climáticos.

No "cultivo das águas"(Figura I), verificou-se uma combinação de alta temperatura e precipitaçào pluvial, no período de granação, responsável certamente pela pior qualidade das sementes, quando comparadas com aquelas obtidas no "cultivo da seca" (Figura II), no qual não foi verificado tal efeito.

Em relação aos teores de macronutrientes nas sementes, observou-se que de maneira geral foram percentualmente superiores, no "cultivo das águas" em relação ao "cultivo da seca", fato este que pode ser 
explicado pelo menor índice pluviométrico verificado no período de frutificação do "cultivo da seca"(Figura II).

Assim sencio, não se constatou relação direta entre $\mathrm{O}$ teor de $\mathrm{Ca}$ nas sementes e qualidade das mesmas, como foi observado por, HARRIS \& BROLMANN (1966), COX et al. (1976), HALLOCK \& ALLISON (1980) para o cultivar Florygiant e SULLIVAN et al. (1974) para o cultivar NC-5. 
4.2.1. Experimento II (área sem calagem).

\title{
4.2.1. Cultivo das Águas
}

\author{
4.2.1.a. Primeira Etapa de Avaliação \\ (após a colheita)
}

\subsection{1.a.1. Teor de água}

Os teores de água das sementes, determinados por ocasião desta etapa de avaliaçào (Tabelas 22 e 23), apresentaram valores em torno de 7,3 \% com pequenas variações entre tratamentos. Logo, não deve ter sido responsáveis pelas diferenças encontradas entre os tratamentos, para as demais caracteristicas avaliadas.

\subsection{1.a.2. Peso de 100 sementes}

Verificando-se os Quadrados Médios da Tabela 21, observa-se diferenças altamente significativas para o contraste $Y 1$, em que as sementes dos tratamentos que não receberam gesso agrícola apresentaram peso de 100 sementes superior a dos tratamentos que receberam gesso agrícola (Tabela 22). Resultado semelhante foi encontrado por QUAGGIO et al. (1982) utilizando o gesso agrícola como fonte de Ca e por MAEDA et al. (1986) e NAKAGAWA et al. (1990) utilizando o calcário como fonte de Ca. Entretanto SICHMANN (1972), FORNASIERI (1987)， CAIRES (1990) e ROSSETTO (1993), não observaram alteração alguma no peso médio das sementes quando da aplicação do Ca.

Diferença altamente significativa também foram observadas quando se analisou a época de aplicação de gesso agrícola (Tabela 23), apresentando peso superior as 
sementes dos tratamentos que receberam gesso agrícola na semeadura, fato este também observado no Experimento I (área com calagem).

O contraste Y2, apresentou também diferença significativa (Tabela 21), revelando peso de 100 sementes superior para as sementes do tratamento que não recebeu NPK em relação a dos tratamentos que receberam (tabela 22), disconcordando do verificado por MAEDA et al. (1986) em que as sementes que receberam apenas NPK apresentaram peso superior aos demais tratamentos.

\subsection{1.a.3. Germinação}

Observando-se os valores dos Quadrados Médios obtidos na análise de variância (Tabela 21), constatou-se que houve diferença significativa para o contraste $Y 1$, onde as sementes dos tratamentos que receberam gesso agrícola apresentaram porcentagem de germinação superior as dos tratamentos que não receberam (Tabela 22), fato este também observado por HALLock \& ALLISON (1980), BELL (1985), COFFELT\& HALLOCK (1986), MAEDA et al. (1986) em que o efeito do Ca foi favorável a germinação.

Diferenças significativas também foram encontradas para a variável local de aplicação de gesso agrícola (Tabela 21), sendo superior a média percentual encontrada para aplicação do gesso agrícola na área total (Tabela 23).

\subsection{1.a.4. Vigor}

Entre os parâmetros que avaliaram o vigor nesta etapa de avaliação (primeira contagem de germinação, envelhecimento acelerado, emergência de plântulas em campo, 
condutividade elétrica e lixiviação de potássiol. Verificou-se diferenças altamente significativas no contraste Y1, para os parâmetros, condutividade elétrica e lixiviação de potassio $(k)$ das sementes e significativa para os parâmetros primeira contagem e envelhecimento acelerado(Tabela 21), indicando melhor qualidade das sementes para os tratamentos que receberam gesso agrícola (Tabela 22). MAEDA et al. (1986), NAKAGAWA et al. (1990) e ROSSETTO (1993) encontraram o mesmo efeito positivo do Ca na qualidade fisiológica das sementes.

Para o fator local de aplicação de gesso agrícola, houve diferenças significativas para os testes primeira contagem e envelhecimento acelerado(Tabela 21), sendo superior a média encontrada para aplicação de gesso agrícola na área total (Tabela 22).

o parâmetro lixiviação de potassio, também apresentou diferenças significativas para o contraste Y4 (Tabela 21), no qual as sementes provenientes do tratamento que não recebeu enxofre mostraram-se superiores em qualidade, às obtidas do tratamento que recebeu o nutriente (Tabela 22).

\subsection{1.a.5. Teor de macronutrientes nas sementes}

Para este experimento (área sem calagem) os macronutrientes que apresentaram diferenças significativas foram $\circ \mathrm{N}, \mathrm{P}, \mathrm{K}$ e Mg. (Tabela 24)

O teor de $\mathrm{N}$ das sementes apresentou diferença altamente significativa para o contraste Y2, verificando-se que as sementes dos tratamentos que receberam adubação NPK apresentaram maior porcentagem de N do que as sementes dos tratamentos que não receberam a adubação NPK(Tabela 25). Diferença significativa para este 
nutriente também foi encontrada na interação (doses de gesso agrícola $x$ local de aplicação de gesso agrícola) (Tabela 24), onde, através do desdobramento da interação (Tabela 24.a), pode-se constatar diferença altamente significativa entre as doses de gesso agrícola quando se aplicou o gesso agrícola no sulco, estabelecendose a seguinte equação de regressão: $Y=5,880000000$ $0,256666667 \mathrm{X})$.

Para $O P$ contido nas sementes, diferença significativa foi encontrada para o contrate Y2, tendo sido verificado que os tratamentos que receberam adubação NPK apresentaram teor de $P$ superior ao daquelas que não receberam a referida adubação (Tabela 25 ).

O K apresentou diferença significativa para - fator doses de gesso agrícola (Tabela 26), estabelecendose a seguinte equação de regressão:(Y=0,9216666667 $\left.0,2450000000 \mathrm{X}+0,0691666667 \mathrm{X}^{2}\right)$. Diferença altamente significativa foi encontrada na interação (doses de gesso agrícola X local de aplicação do gesso agrícola), onde, através do desdobramento da interação (Tabela 24.a), podese constatar diferença altamente significativa entre as doses de gesso agrícola quando se aplicou o gesso agrícola no sulco, estabelecendo-se a seguinte equaçào de regressão: $\left(Y=1,298333333-0,680000000 X+0,171666667 X^{2}\right)$ e diferença significativa entre as doses, quando se aplicou o gesso agrícola na área total, revelando a seguinte regressão: $(Y=0,6561111111+0,0566666667 X)$.

O teor de $\mathrm{Mg}$ nas sementes apresentou diferença significativa no contraste Y1 (Tabela 25), no qual as sementes dos tratamentos que não receberam gesso agrícola revelaram maior porcentagem de $\mathrm{Mg}$ do que as dos tratamentos que receberam. 


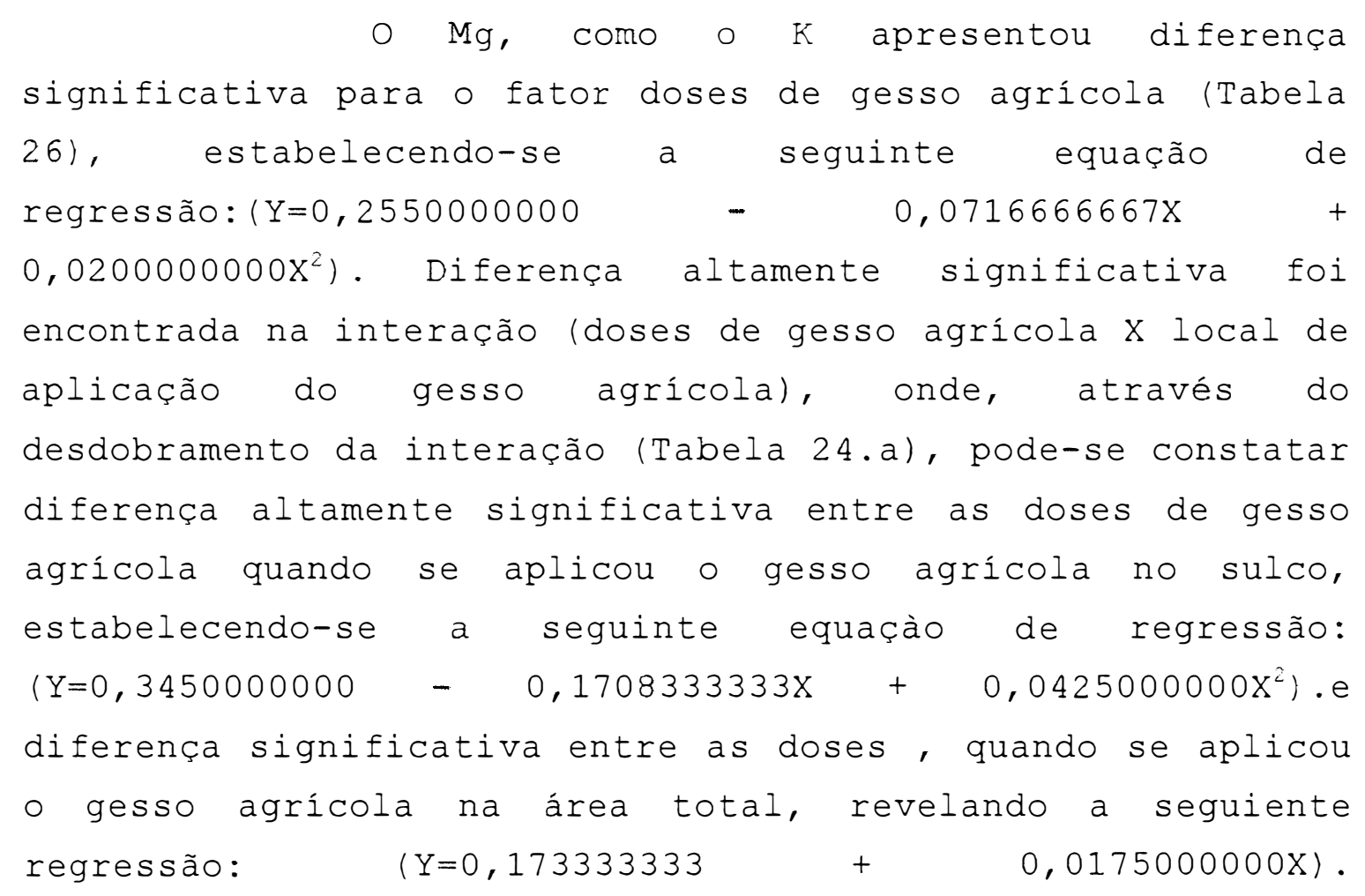




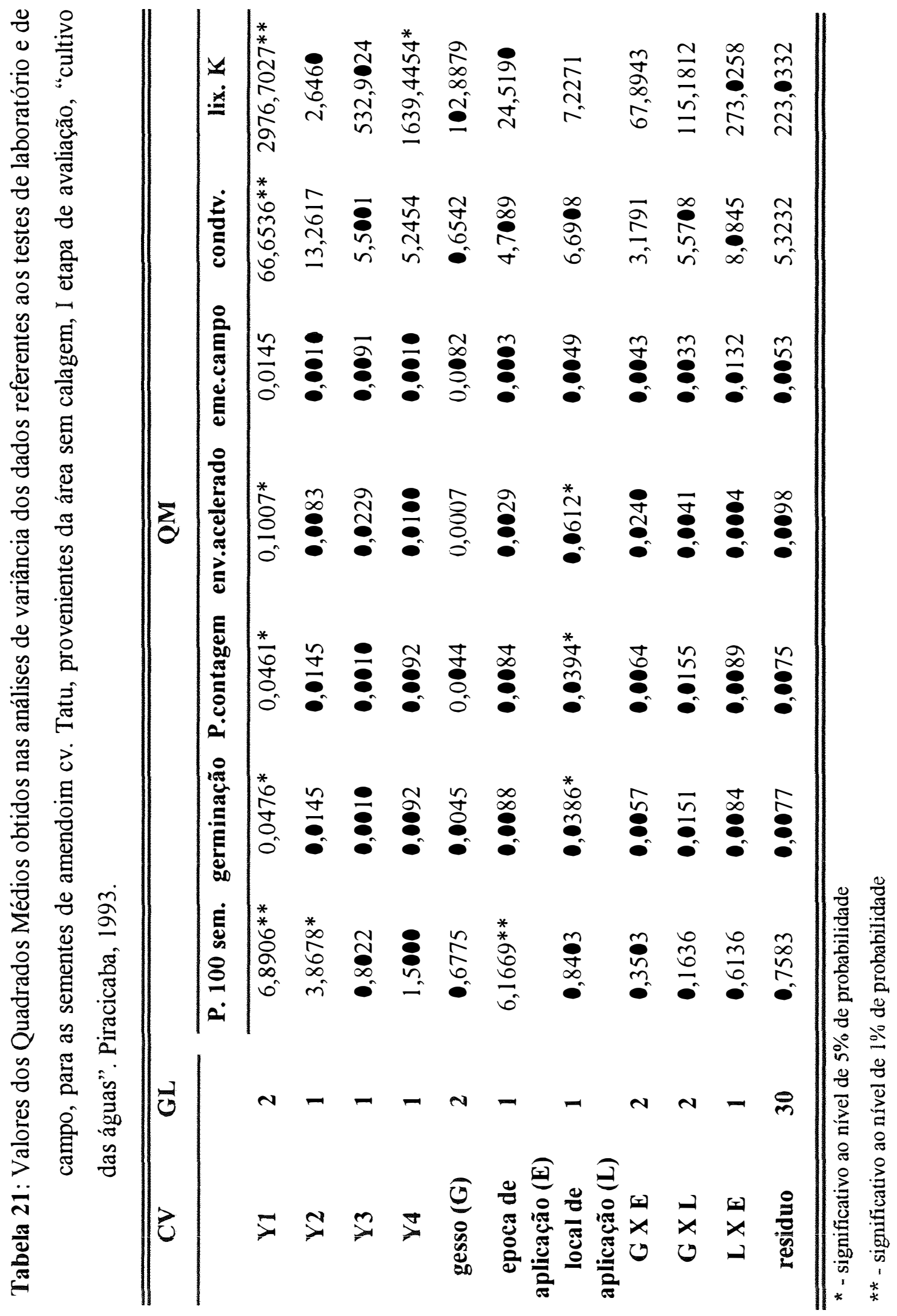




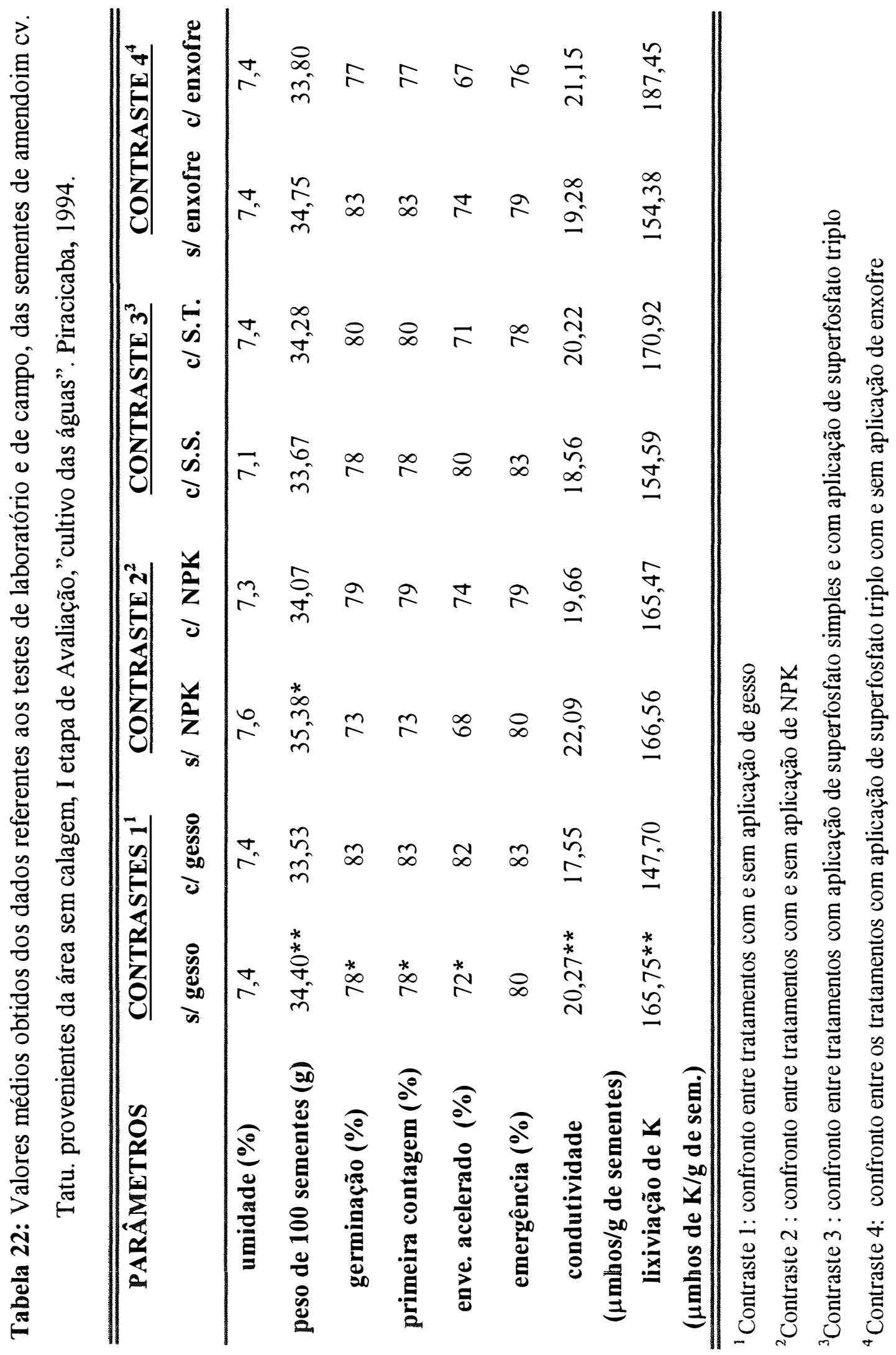




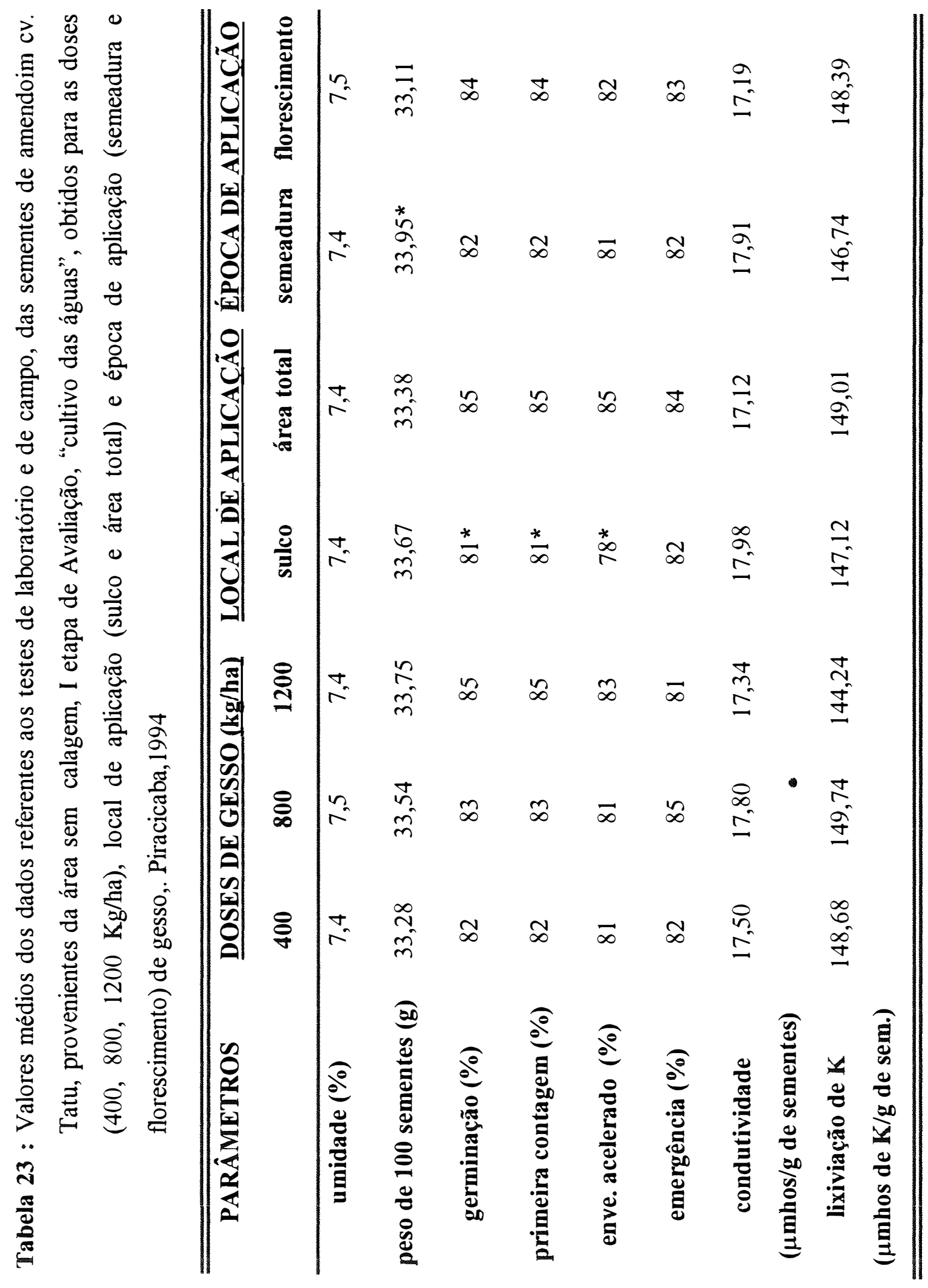




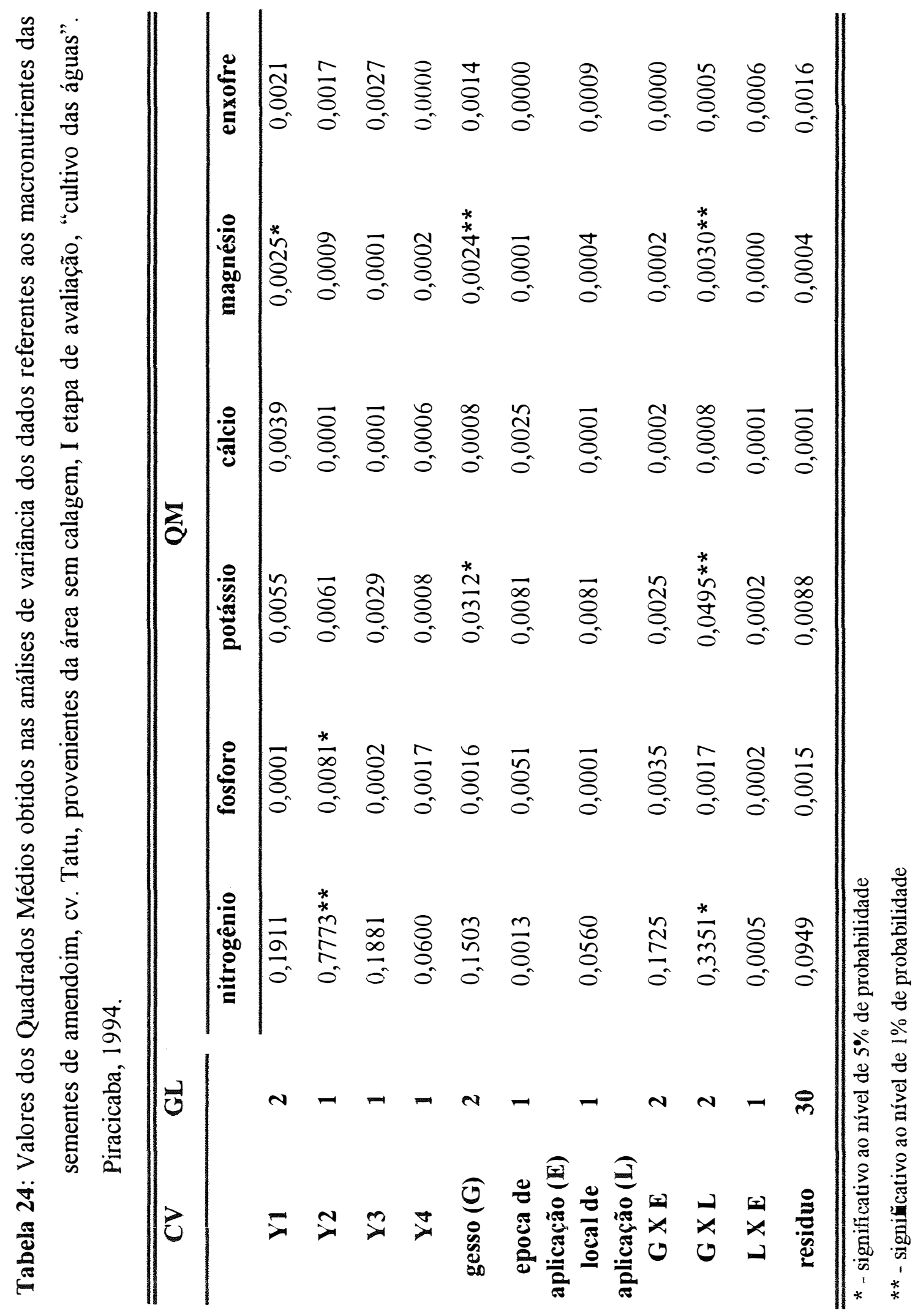


Tabela 24 a. :Desdobramento das interações significativas referentes a Tabela 24.

\begin{tabular}{|c|c|c|}
\hline \multicolumn{3}{|l|}{ MACRONUTRIENTES } \\
\hline Nitrogênio & \multicolumn{2}{|l|}{$(G \times L)^{\star}$} \\
\hline \multirow[b]{2}{*}{ Doses de Gesso Agrícola } & \multicolumn{2}{|c|}{ Local de aplicação } \\
\hline & localizado & área total \\
\hline G 1 & 5,64 & 5,43 \\
\hline G 2 & 5,33 & 5,34 \\
\hline \multirow[t]{2}{*}{ G 3} & 5,13 & 5,57 \\
\hline & $\star \star$ & \\
\hline \multirow[t]{2}{*}{ Potássio } & $(G \times L)^{\star}$ & \\
\hline & \multicolumn{2}{|c|}{ Local de aplicação } \\
\hline Doses de gesso agrícola & localizado & área total \\
\hline G 1 & 0,79 & 0,70 \\
\hline G 2 & 0,63 & 0,79 \\
\hline \multirow[t]{2}{*}{ G 3} & $\mathbf{0 , 8 0}$ & 0,82 \\
\hline & $* *$ & * \\
\hline \multirow[t]{2}{*}{ magnésio } & $(G \times L)^{\star}$ & \\
\hline & \multicolumn{2}{|c|}{ Local de aplicação } \\
\hline Doses de gesso agrícola & localizado & área total \\
\hline G 1 & 0,22 & 0,19 \\
\hline G 2 & 0,17 & 0,21 \\
\hline \multirow[t]{2}{*}{ G 3} & 0,22 & 0,23 \\
\hline & $* *$ & * \\
\hline
\end{tabular}




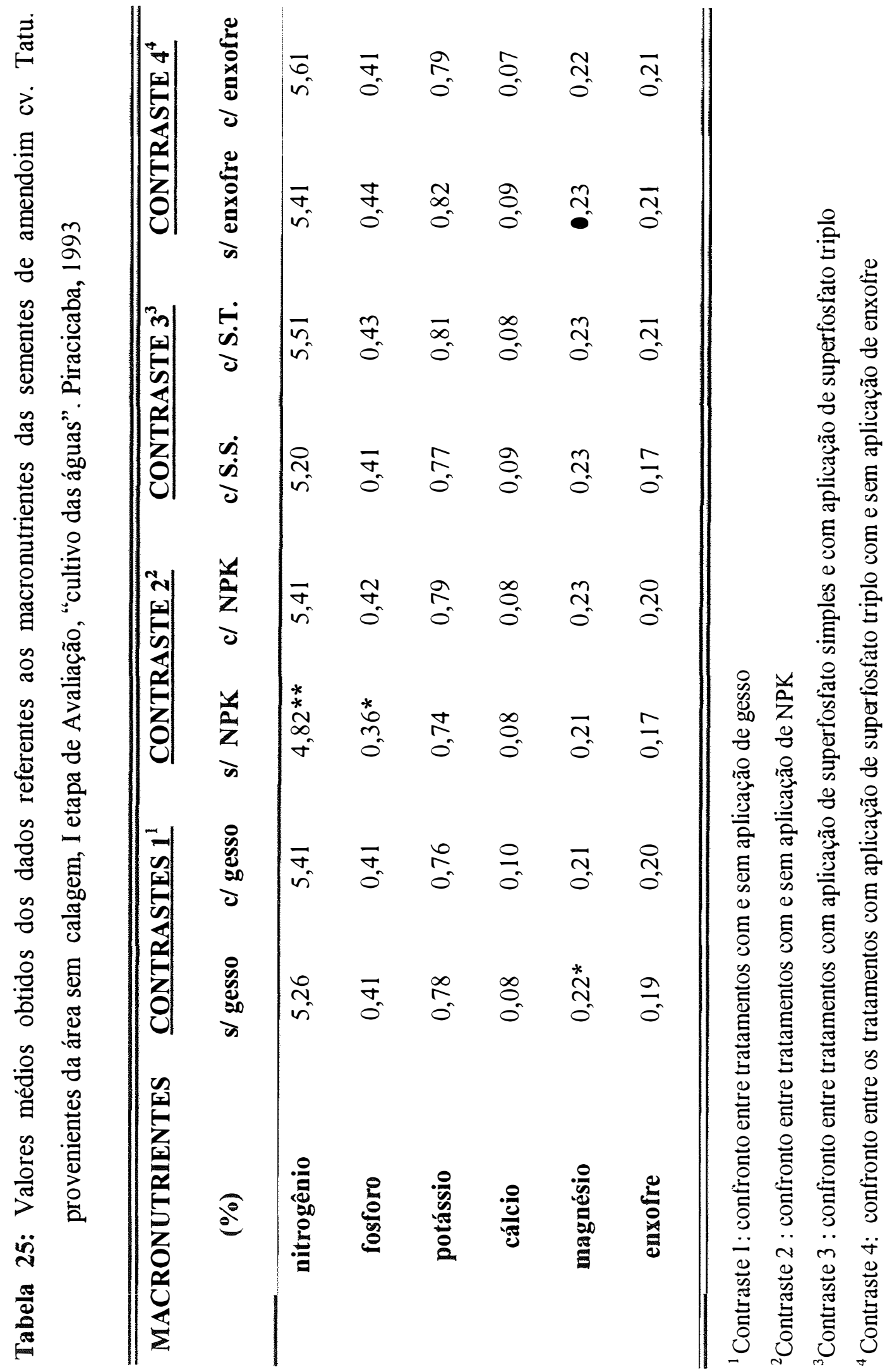




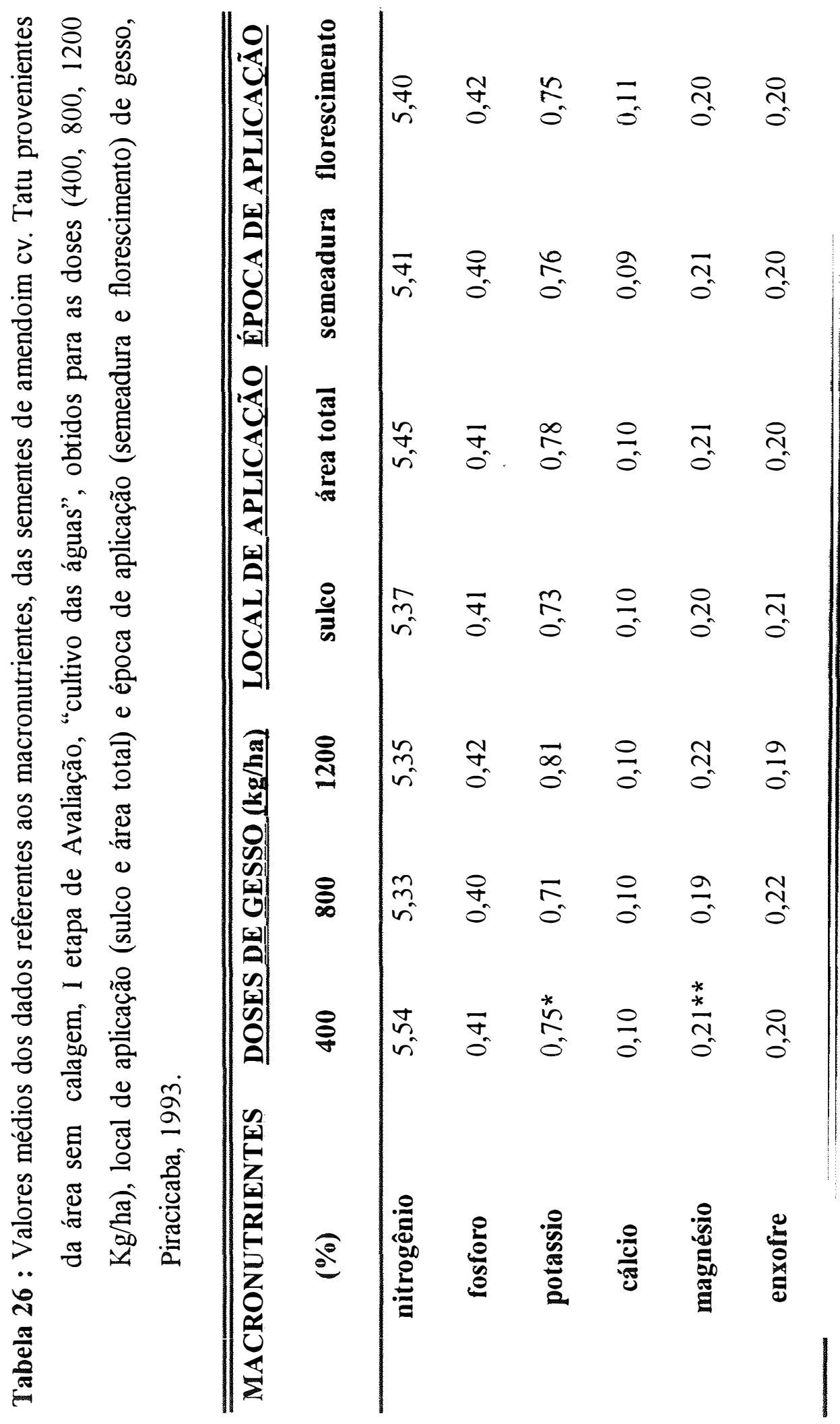




\subsection{1.b. Segunda Etapa de Avaliação \\ ( 6 meses de armazenamento)}

\subsection{1.b.1. Teor de água}

O teor de água das sementes nesta etapa de avaliação, permaneceu entre 7,5 à 8,1 \% (Tabelas 28 e 29), indicando o mesmo nível de uniformização entre os tratamentos, já comentados anteriormente.

Em relação a comparação dos teores de água das sementes encontrados na I etapa de avaliação (após a colheita) (Tabelas 22 e 23) com os encontrados nesta etapa, pode-se verificar que praticamente não houve alterações nos teores de água durante o armazenamento; mesmo comportamento foi observado no Experimento I e também por RosSETTO (1993) para o mesmo período de armazenamento.

O período e o ambiente de armazenamento (Eigura III) foi o mesmo do Experimento I (área com calagem).

\subsection{1.b.2. Germinação}

Nesta etapa de avaliação, não foi detectado nenhuma diferença significativa entre os diversos fatores analisados (Tabela 27).Entretanto, ao se comparar os valores absolutos nesta etapa de avaliação (Tabelas 28 e 29) com os valores obtidos na I etapa de avaliação (após colheita) (Tabelas 22 e 23), verifica-se que as porcentagens de germinação encontradas nesta etapa foram inferiores. 


\subsection{1.b.3. Vigor}

Dentre os parâmetros que avaliaram $\circ$ vigor nesta etapa de avaliação, verificou-se diferenças significativas para os testes de envelhecimento acelerado, condutividade elétrica e lixiviação de potássio (Tabela 27 ) .

Assim, para os testes de envelhecimento acelerado e condutividade elétrica houve efeito significativo para o contraste $Y 4$, tendo sido observado que - tratamento sem enxofre foi superior ao tratamento contendo o nutriente (Tabela 28).

Para os parâmetros condutividade elétrica e lixiviação de potássio, diferenças altamente significativas foram encontradas para o contraste $Y 1$, em que a quantidade de íons e ions $\mathrm{K}^{+}$lixiviados das sementes foram maiores para os tratamentos que não receberam gesso agrícola, indicando pior qualidade das sementes (Tabela 28 ).

Diferença altamente significativa também foi encontrada no parâmetro condutividade, para o contraste y3 em que maior quantidade de íons lixiviados das sementes foram observadas nos tratamentos com superfosfato triplo (ST) (Tabela 28), indicando pior qualidade das sementes em relação ao material que recebeu o(SS) .

Ao se comparar os valores absolutos nesta etapa de avaliação (Tabelas 28 e 29) com os valores obtidos na I etapa de avaliação (após a colheita) (Tabelas 22 e 23), verificou-se valores inferiores para todos os parâmetros utilizados nesta etapa. 


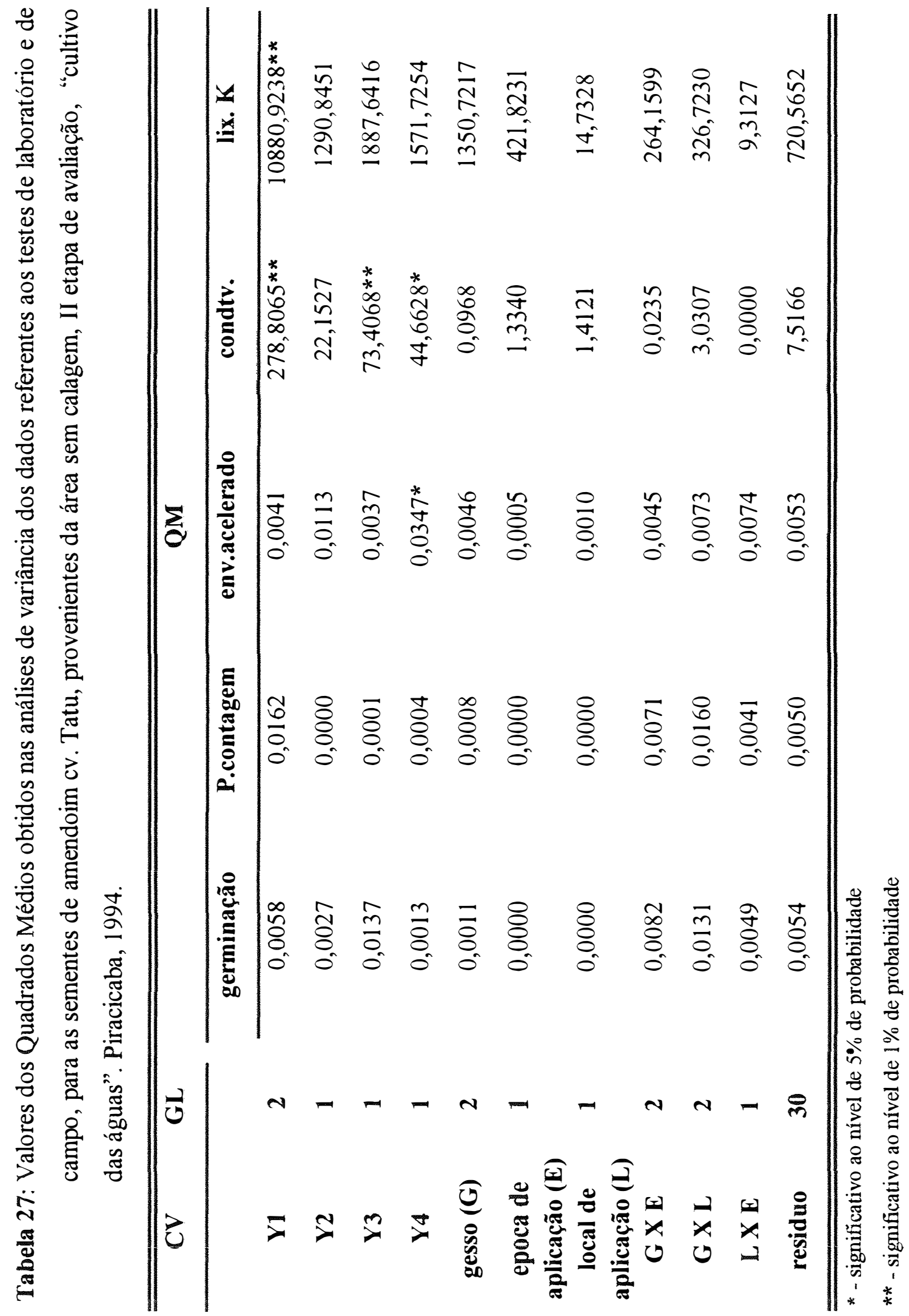




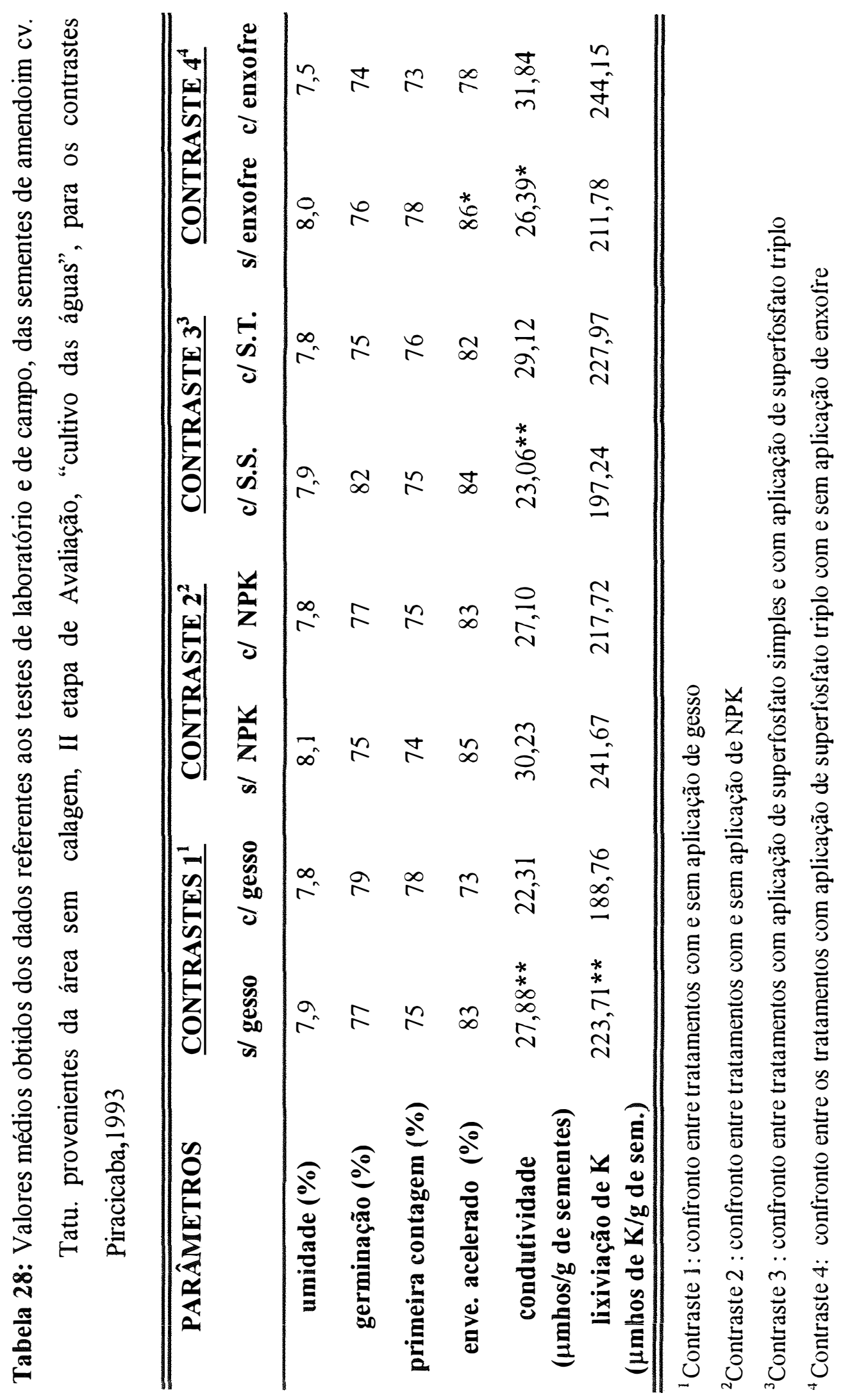




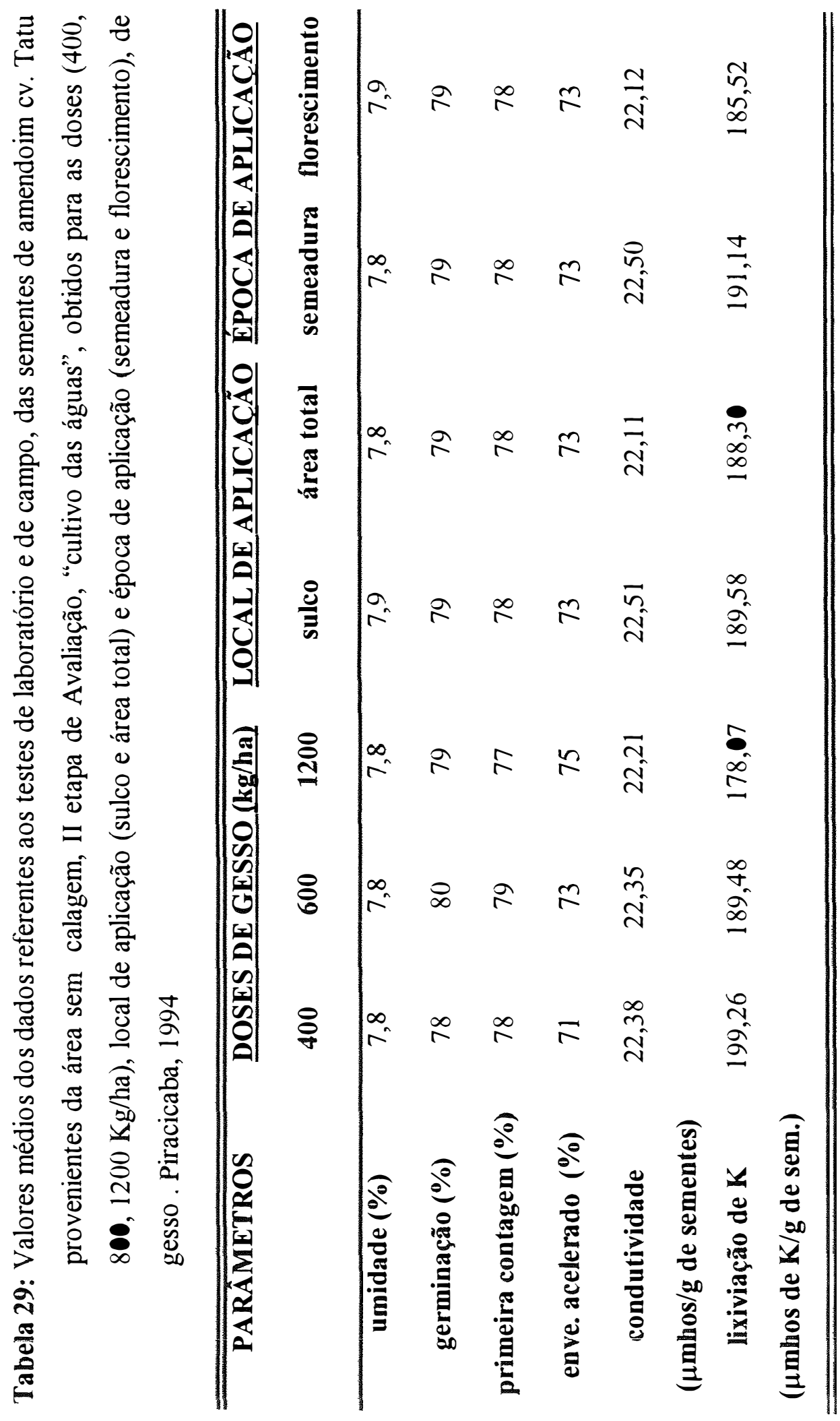




\subsubsection{Cultivo da Seca (efeito residual)}

\subsection{2.a. Primeira Etapa de Avaliação (após a colheita)}

\subsection{2.a.1. Teor de água}

O teor de água das sementes para esta etapa de análise, permaneceu entre 6,5 à 7,0 (Tabelas 31 e 32), não sendo constatado assim, diferenças que pudessem alterar alguns dos resultados obtidos pelos testes que avaliaram a qualidade das sementes nesta etapa.

\subsection{2.a.2. Peso de 100 sementes}

Pela análise dos quadrados médios da tabela 30 observa-se que nenhuma diferença significativa foi encontrada para este parâmetro, fato este que apesar de não ter sido observado por NAKAGAWA et al. (1990), foi observado na área com calagem (experimeto I) nesta pesquisa.

Entretanto, ao se comparar os valores absolutos obtidos no "cultivo das águas", pode-se verificar que 0 peso de 100 sementes obtidos neste cultivo (efeito residual)(Tabelas 31 e 32), apresentou-se inferior ao observado no cultivo das águas (efeito imediato) (Tabelas 22 e 23). Resultado semelhante a este, foi também encontrado no Experimento I (área com calagem) e por NAKAGAWA et al. (1990) na área experimental do município de Marília, mas não confirmado na àrea experimental de Julio Mesquita. 


\subsection{2.a.3. Germinação}

A germinação (Tabela 30) apresentou diferenças significativas quando se analisou a interação (doses de gesso agrícola $x$ local de aplicação), onde verificou-se pelo desdobramento da interação (Tabela 30. a) que as sementes obtidas da dose 1 de gesso agrícola (400 Kg/ha), apresentaram maior porcentagem de germinação quando se aplicou o insumo de forma localizada; por outro lado, quando o gesso agrícola foi aplicado na área total, diferenças significativas foram encontradas para as doses de gesso agrícola, ajustando-se a regressão linear ( $Y=$ $1,165640546+0,066348667 x)$.

Entretanto, não foi verificado diferenças significativas quando se analisou o efeito isolado do insumo, o que foi verificado também na área com calagem (experimeto I), mas não observado por NAKAGAWA et al. (1990).

Ao se comparar a porcentagem de germinação em valores absolutos, entre este cultivo e o cultivo das águas, observa-se de uma maneira geral a superioridade em valores absolutos deste cultivo para todos os fatores analisados, fato este observado também no Experimento I.

\subsection{2.a.4. Vigor}

Para os parâmetros que foram utilizados nesta etapa de avaliação (Tabela 30), apenas a primeira contagem de germinação e a lixiviação de potássio apresentaram diferenças significativas. Verificando-se que a primeira contagem de germinação das sementes dos tratamentos que receberam gesso agrícola apresentaram-se superiores às dos que não receberam o insumo (Tabela 31), tal fato foi também observado por Nakagawa et al.(1990) e 
na área com calagem (experimeto I). Em contrapartida, a lixiviação de potássio apresentou diferenças significativas nos contrastes $Y 3$ e Y4, pelos quais constatou-se, que o tratamento que recebeu superfosfato simples apresentou-se superior aos tratamentos que receberam superfosfato triplo, assim como, o tratamento que recebeu enxofre em relação ao que não recebeu (Tabela 31).

Ao se comparar todos os parâmetros utilizados nesta etapa para avaliar o vigor das sementes com os mesmos parâmetros utilizados no cultivo das águas, constatou-se que estes se revelaram superiores, com exceção feita à emergência em campo; a mesma situação foi observada na área com calagem (experimento I).

\subsection{2.a.5. Teor de macronutrientes nas sementes.}

Entre os teores de macronutrientes analisados, apenas $O \mathrm{~N}, \mathrm{P}$ e $\mathrm{K}$ apresentaram diferenças significativas para os fatores análisados (Tabela 33).

Para o N, tal diferença foi encontrada para - contraste Y3, quando se analisou as sementes do tratamento que recebeu superfosfato-simples (SS) em relação as dos tratamentos que receberam o superfosfato-triplo (ST), sendo superior a porcentagem de $\mathrm{N}$ encontrada nas sementes que receberam o ST (Tabela 34).

A diferença significativa encontrada para o P foi para o contrate Yl, ao se analisar as sementes dos tratamentos que não receberam gesso agrícola em relação às dos tratamentos que receberam, sendo superior a porcentagem de $P$ encontrada nas sementes dos tratamentos que não receberam $\bigcirc$ insumo (Tabela 34). Mesmo comportamento foi verificado para o K (Tabela 34 ). 


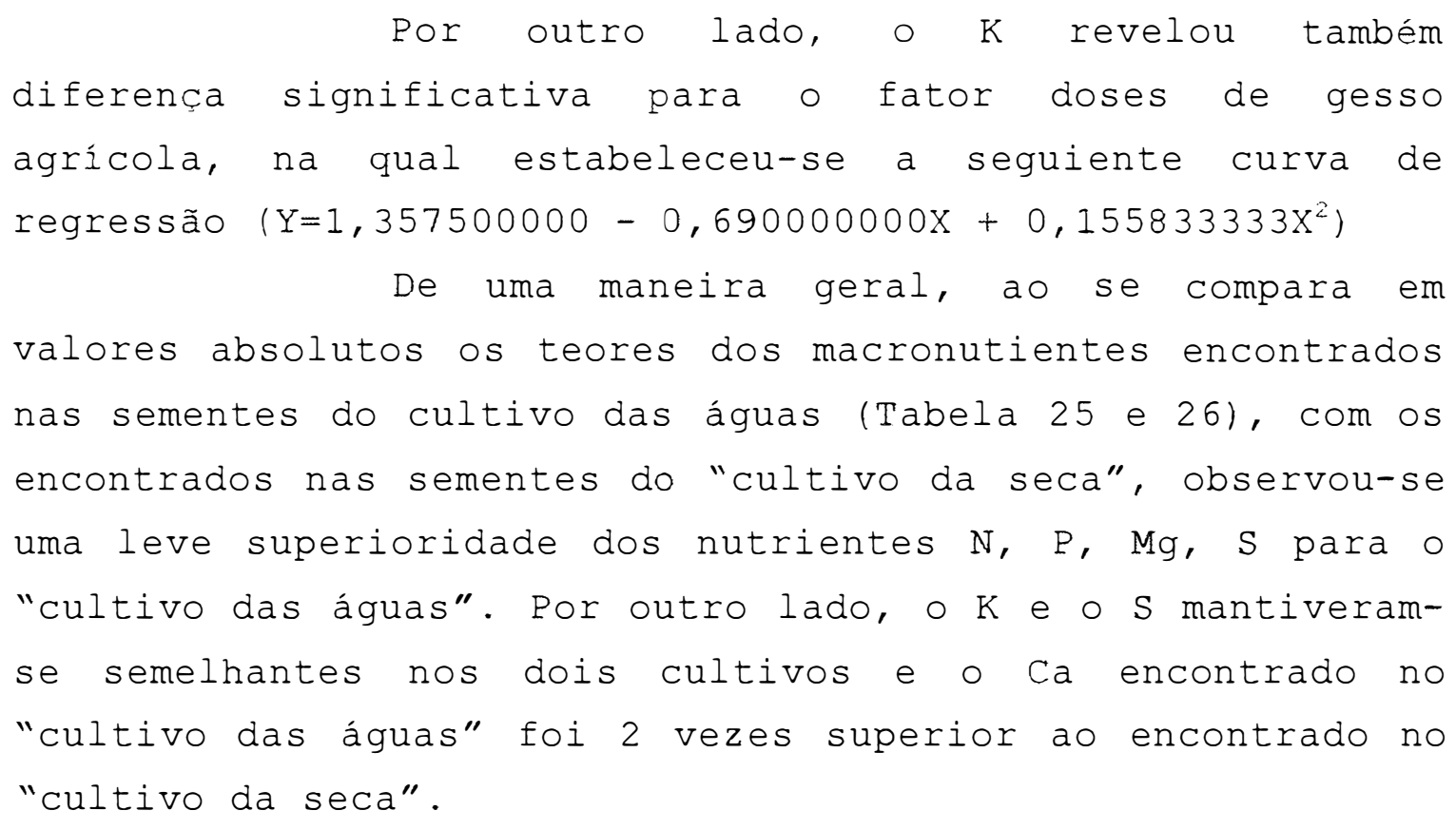




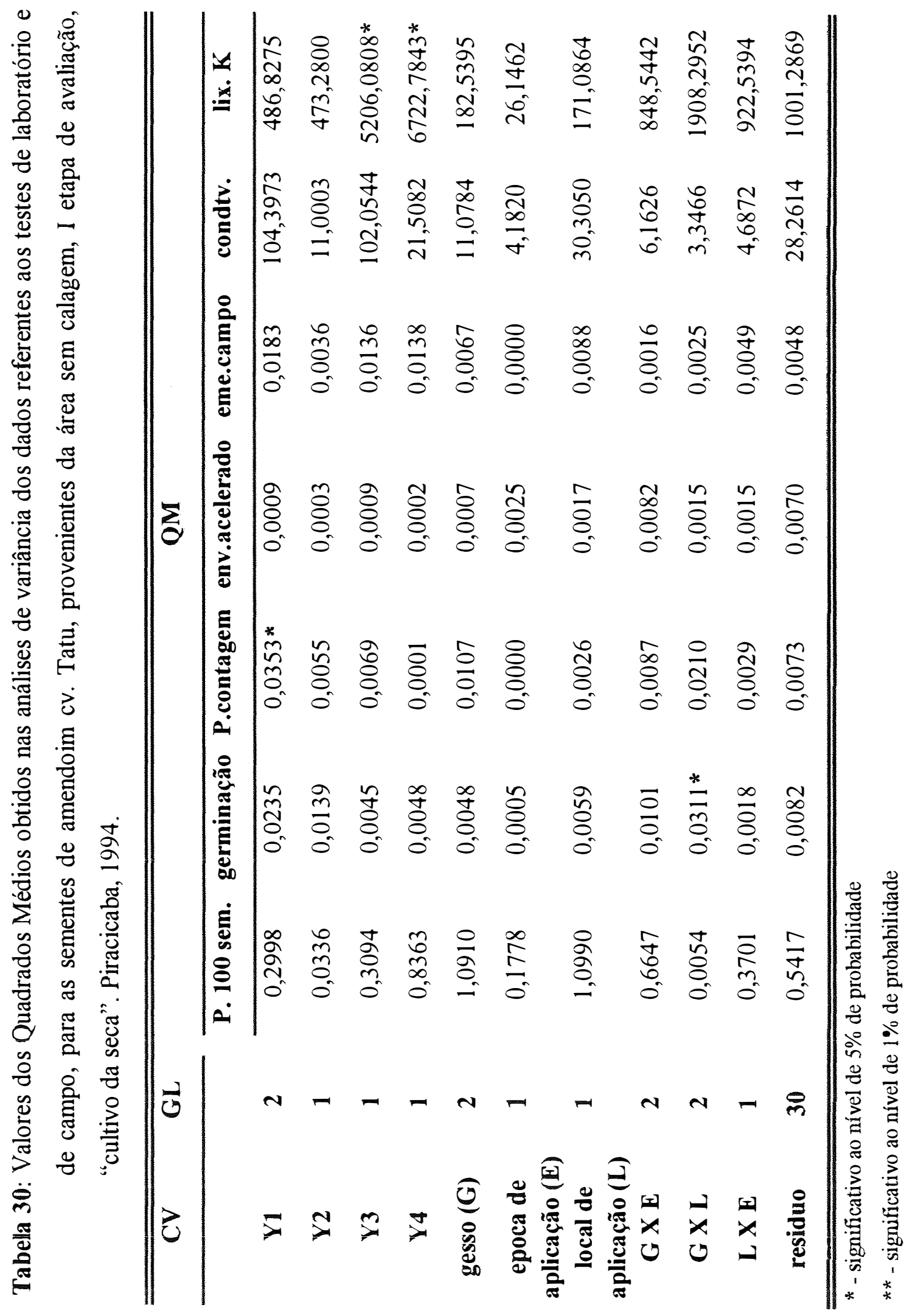


Tabela 30 a. :Desdobramento das interações significativas referentes a Tabela 30.

\begin{tabular}{lcc}
\hline \hline PARÂMETROS & \multicolumn{2}{l}{$(\text { G X L })^{*}$} \\
\hline germinação & \multicolumn{2}{c}{ Local de aplicação } \\
\cline { 2 - 3 } Doses de gesso agrícola & localizado & área total \\
\hline G 1 & 95 & 89 \\
G 2 & 94 & 91 \\
G 3 & 92 & 96 \\
\hline
\end{tabular}




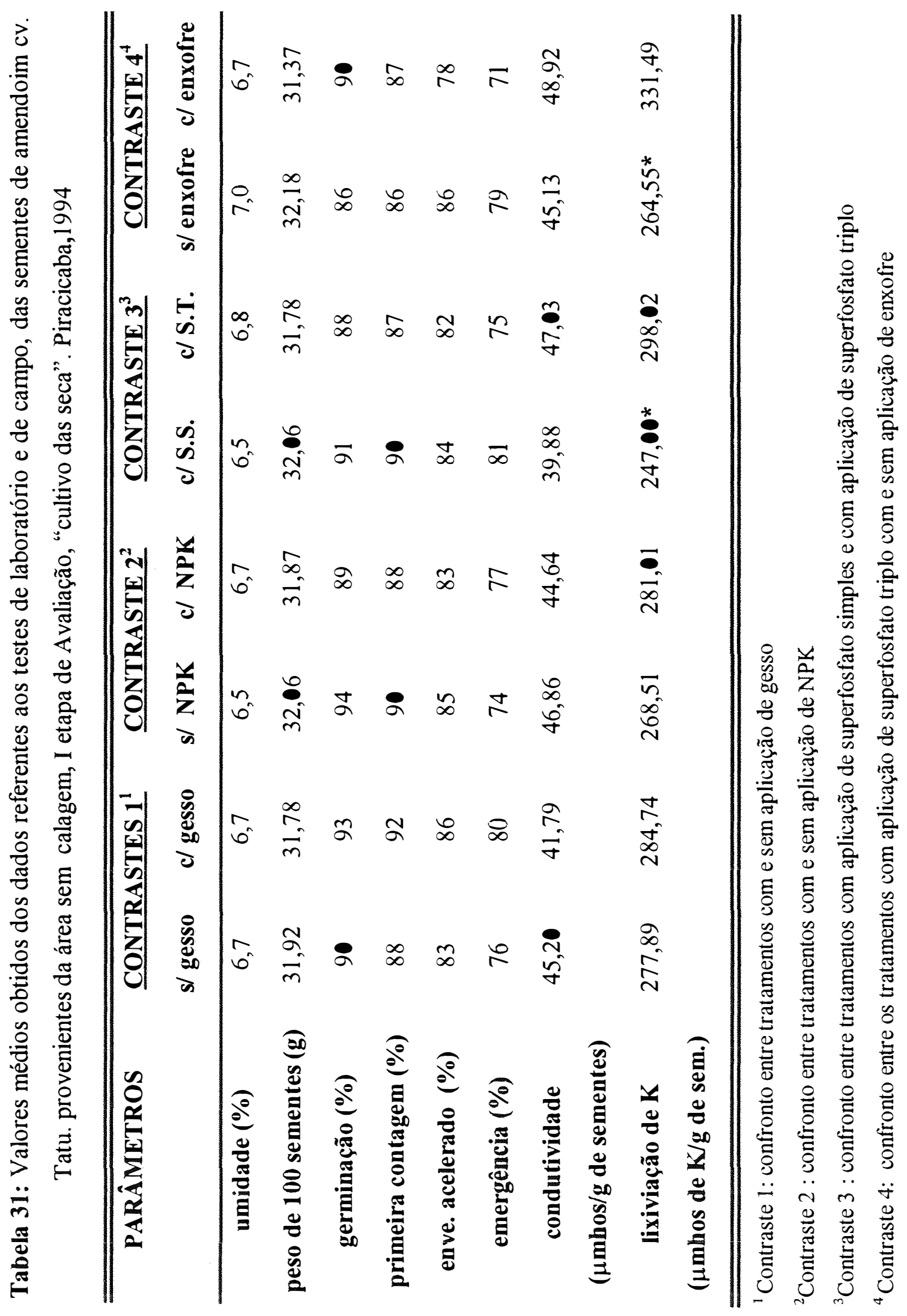




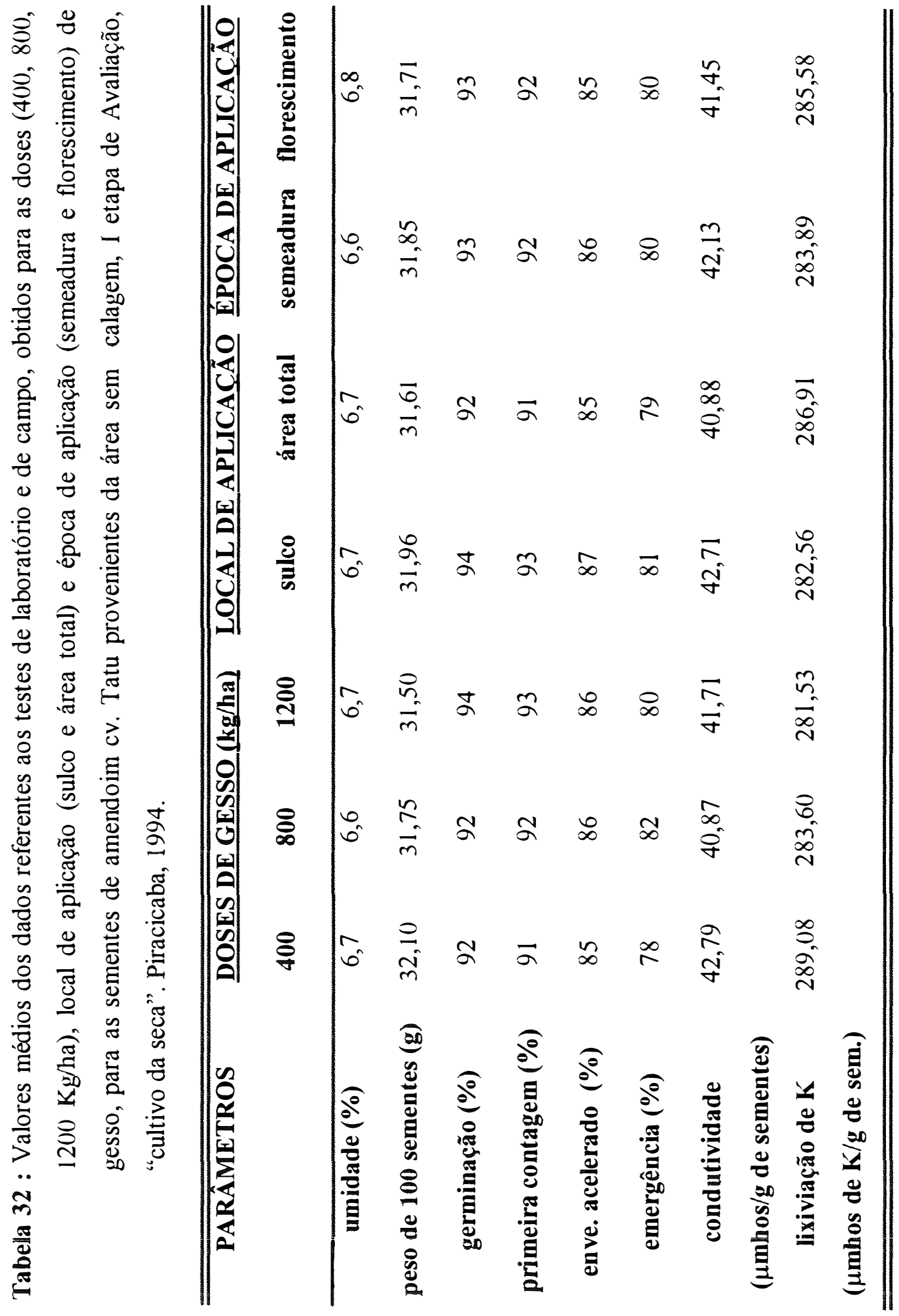




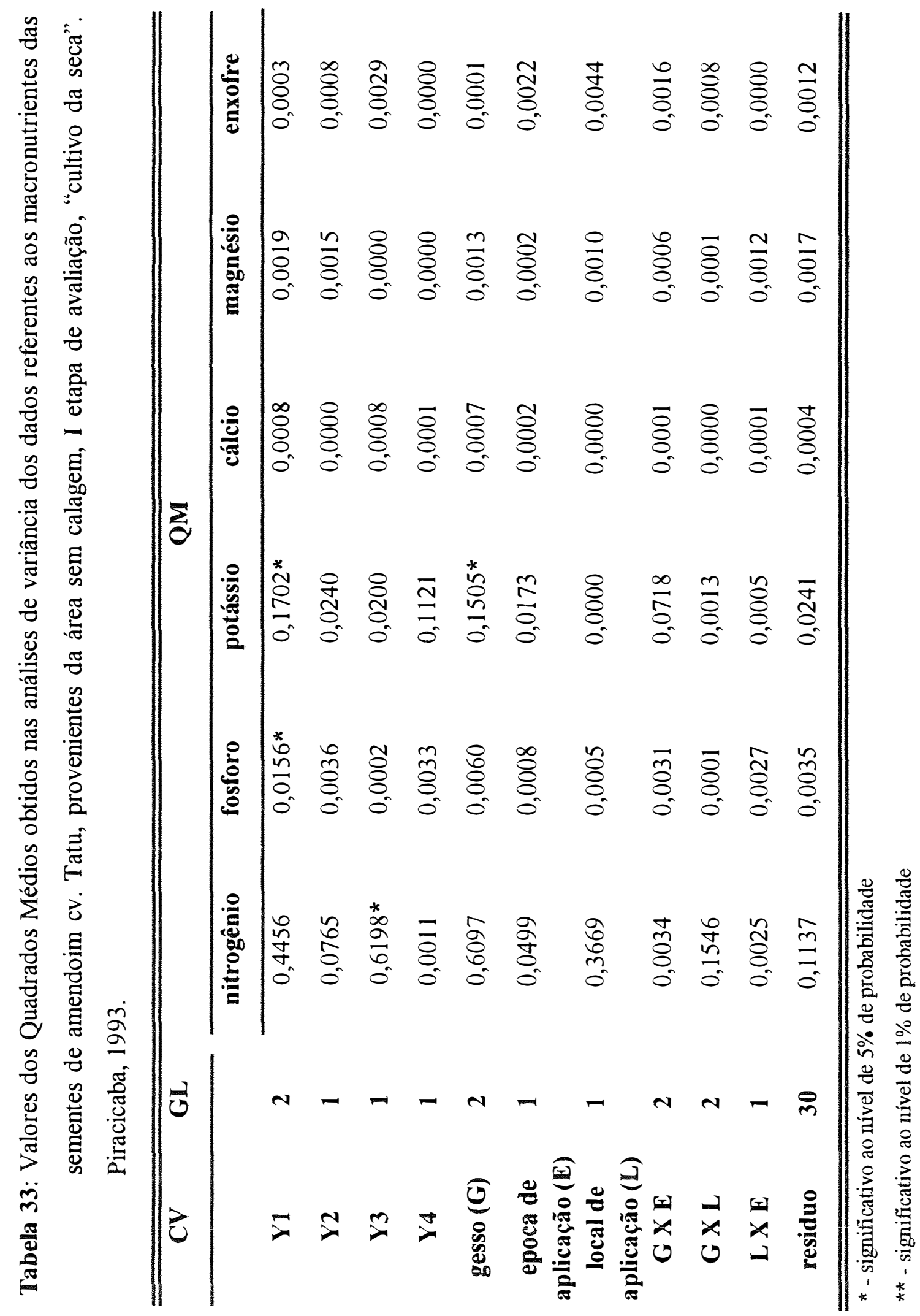




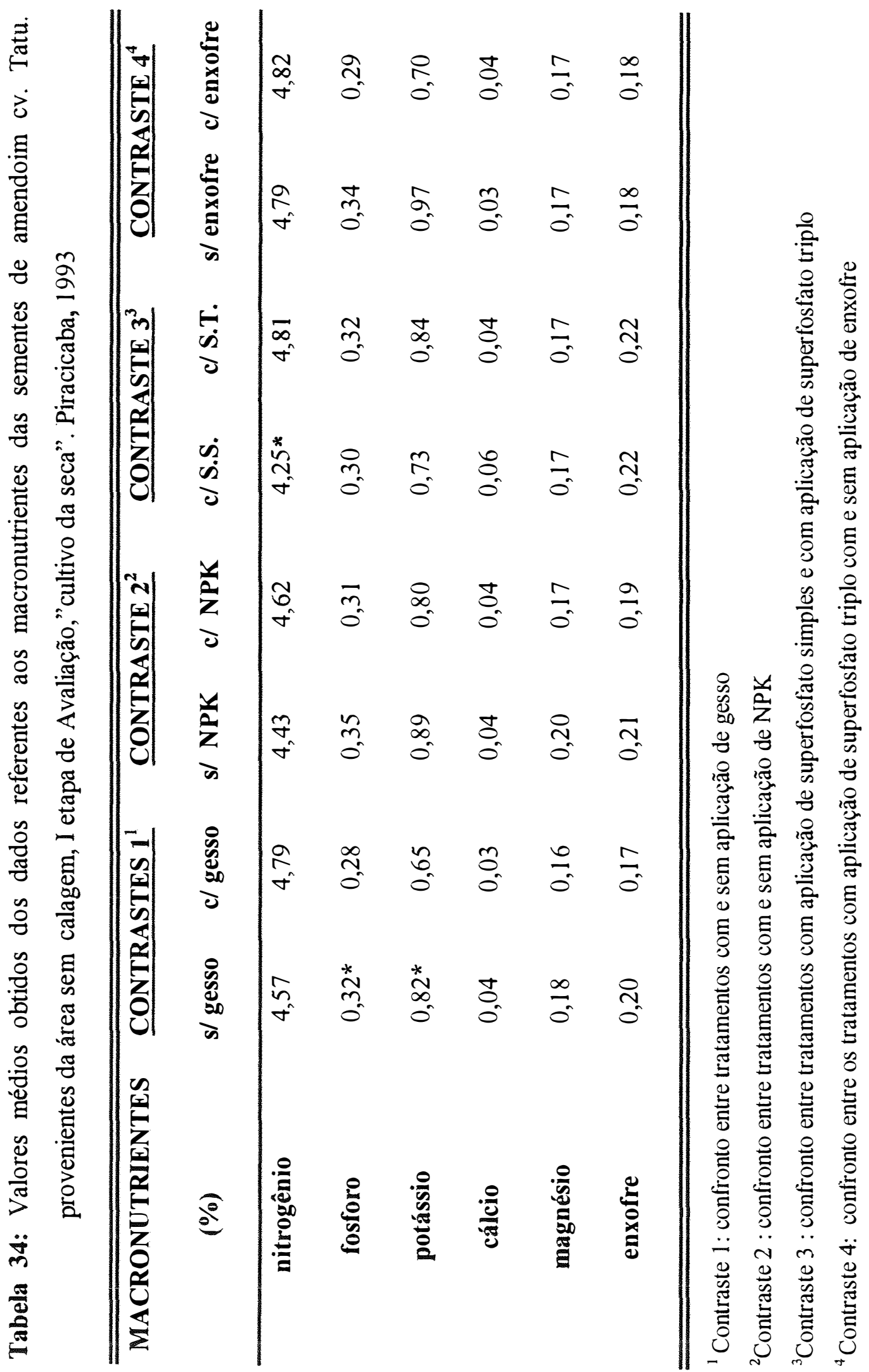




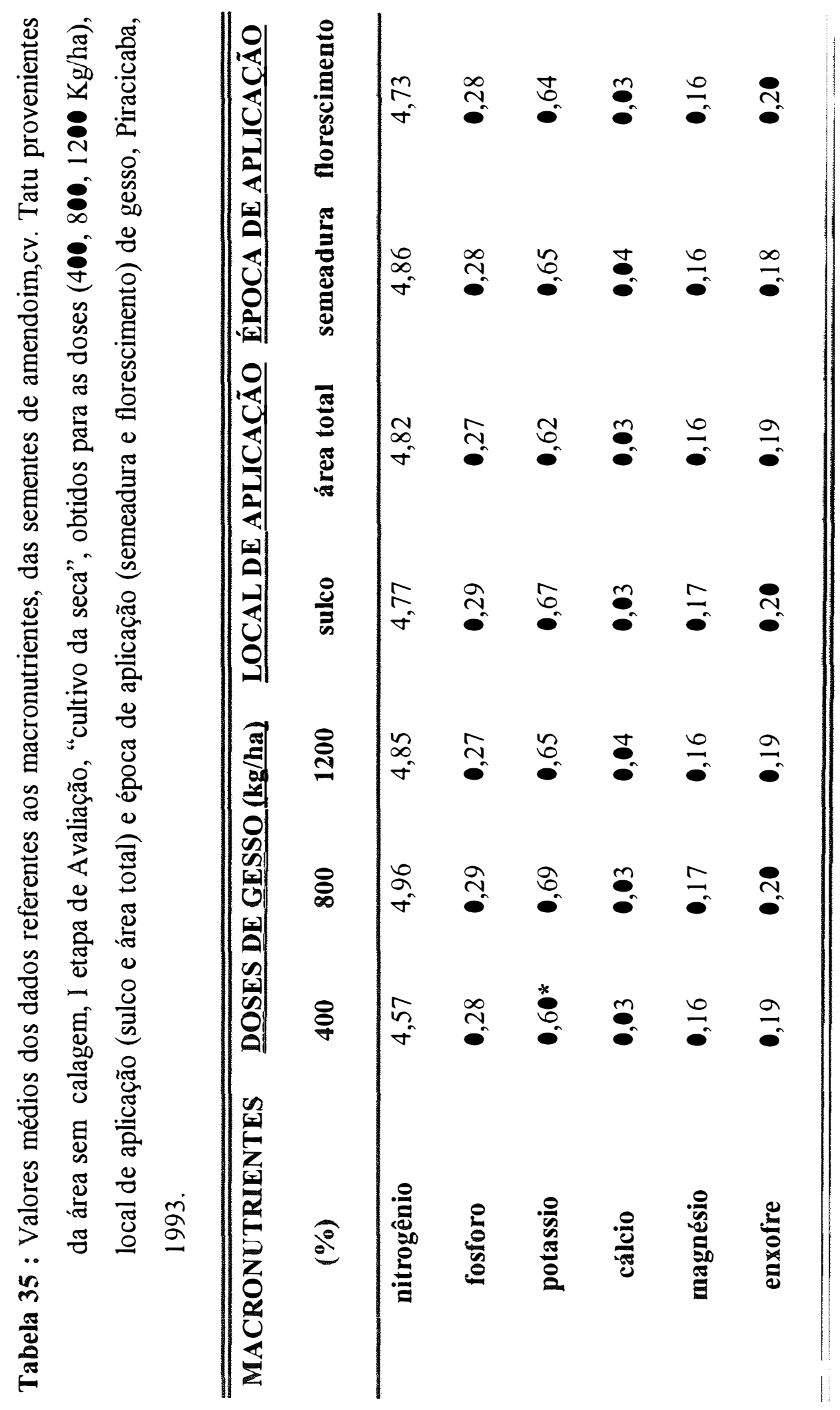




\subsection{2.b. Segunda Etapa de Avaliação (6 meses de armazenamento)}

\subsection{2.b.1. Teor de água}

O teor de água das sementes para esta etapa de análise, permaneceu entre 5,5 à 6,1 (Tabelas 37 e 38), não apresentando diferenças acentuadas entre os tratamentos - que se mostra conveniente para a condução dos testes destinados a avaliar a qualidade das sementes, como já foi citado anteriormente.Por outro lado, os referidos teores de água são considerados adequados para o armazenamento de sementes de amendoim.

O período e o ambiente de armazenamento (Eigura IV) foram os mesmos do Experimento I (área com calagem).

Comparando-se o teor de água das sementes nesta etapa com os obtidos na I etapa de avaliação (inicio de armazenamento) (Tabela 31 e 32), verificou-se que quase não houve alteração do teor do mesmo. Desta maneira, o teor de água das sementes não deve ter sido, o responsável pelo decrescimo do poder germinativo e vigor das sementes, já que segundo TELLA et al. (1976) sementes com umidade original de 7,0\% mantiveram razoável poder germinativo até aos noves meses, e sementes com 4,5\% e 6,0\% de umidade apresentaram germinação alta em todos os períodos testados.

\subsection{2.b.2.Germinação}

Pela análise dos quadrados médios verificados na Tabela 36, constata-se que não houve nenhuma diferença significativa entre os fatores análisados. Entretanto, ao se analisar os valores absolutos encontrados nesta etapa de avaliação (Tabela 37 e 38) com os 
encontrados na I etapa de avaliação (após a colheita) (Tabela 31 e 32), observar-se uma leve queda das porcentagens nesta etapa de avaliação.

\subsection{2.b.3. Vigor}

Para os parâmetros que avaliaram o vigor nesta etapa de avaliaçào (Tabela 36), apenas a primeira contagem de germinação e a lixiviação de potássio das sementes apresentaram diferenças significativas. Sendo que, para $\circ$ parâmetro primeira contagem esta diferença apresentou-se no contraste $Y 2$, no qual as sementes dos tratamentos que receberam adubação com NPK revelaram maior porcentagem de plântulas normais do que as dos tratamentos que não receberam esta adubação (Tabela 37).

A lixiviação de potássio das sementes, apresentou-se de forma semelhante ao parâmetro primeira contagem de germinação em relação ao contrate Y2, no qual as sementes dos tratamentos com NPK mostraram-se superiores às do tratamento sem NPK, com uma diferença altamente significativa. Mesma diferença foi encontrada para o contraste $Y 1$, em que as sementes dos tratamentos que receberam gesso agrícola liberaram menor quantidade de ions potassicos, indicando melhor qualidade das sementes (Tabela $37)$.

Ao se comparar os valores absolutos nesta etapa de avaliação com os valores obtidos na I etapa de avaliação (após a colheita) (Tabelas 31 e 32), verificou-se valores inferiores para todos os parâmetros analizados. 


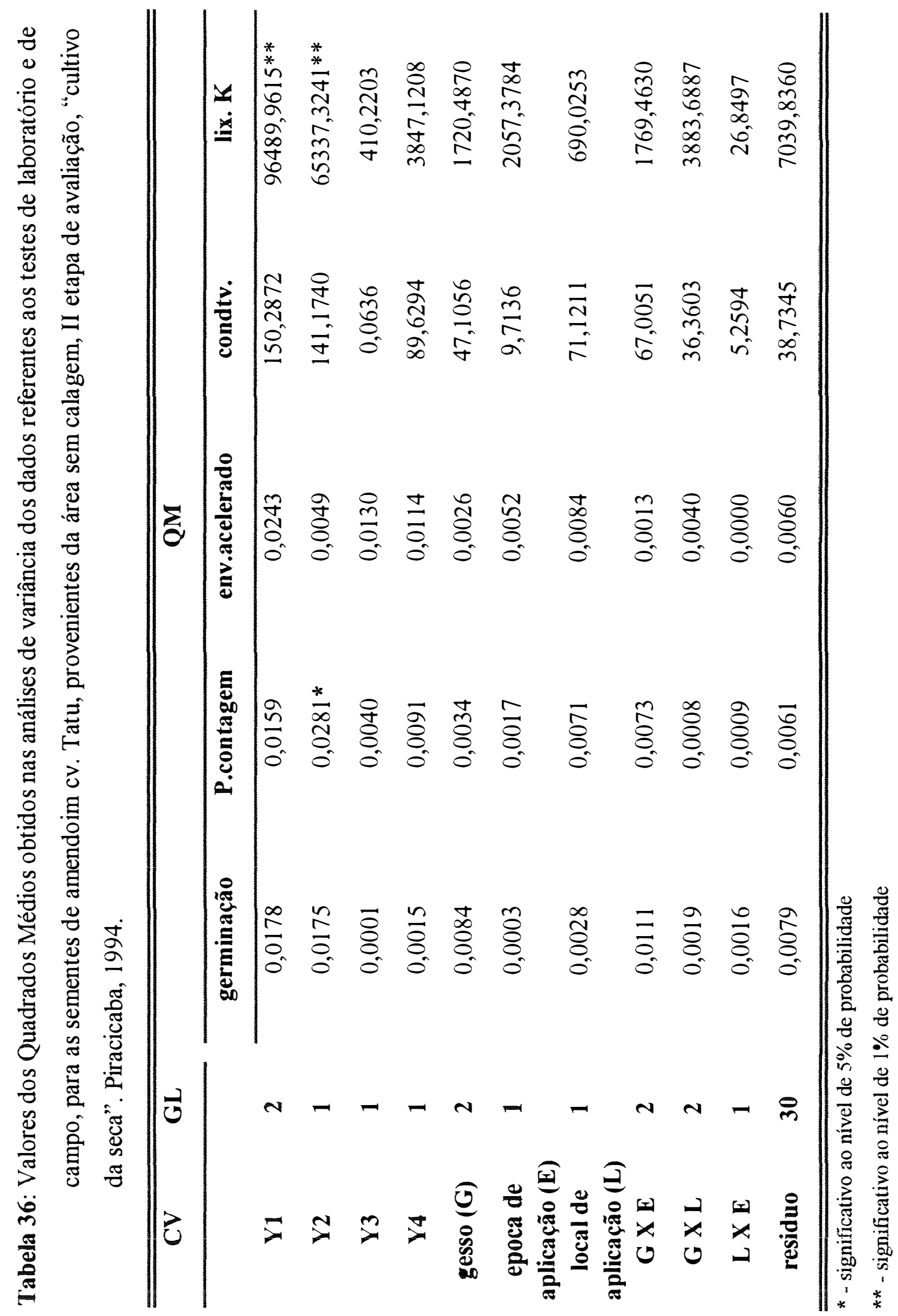




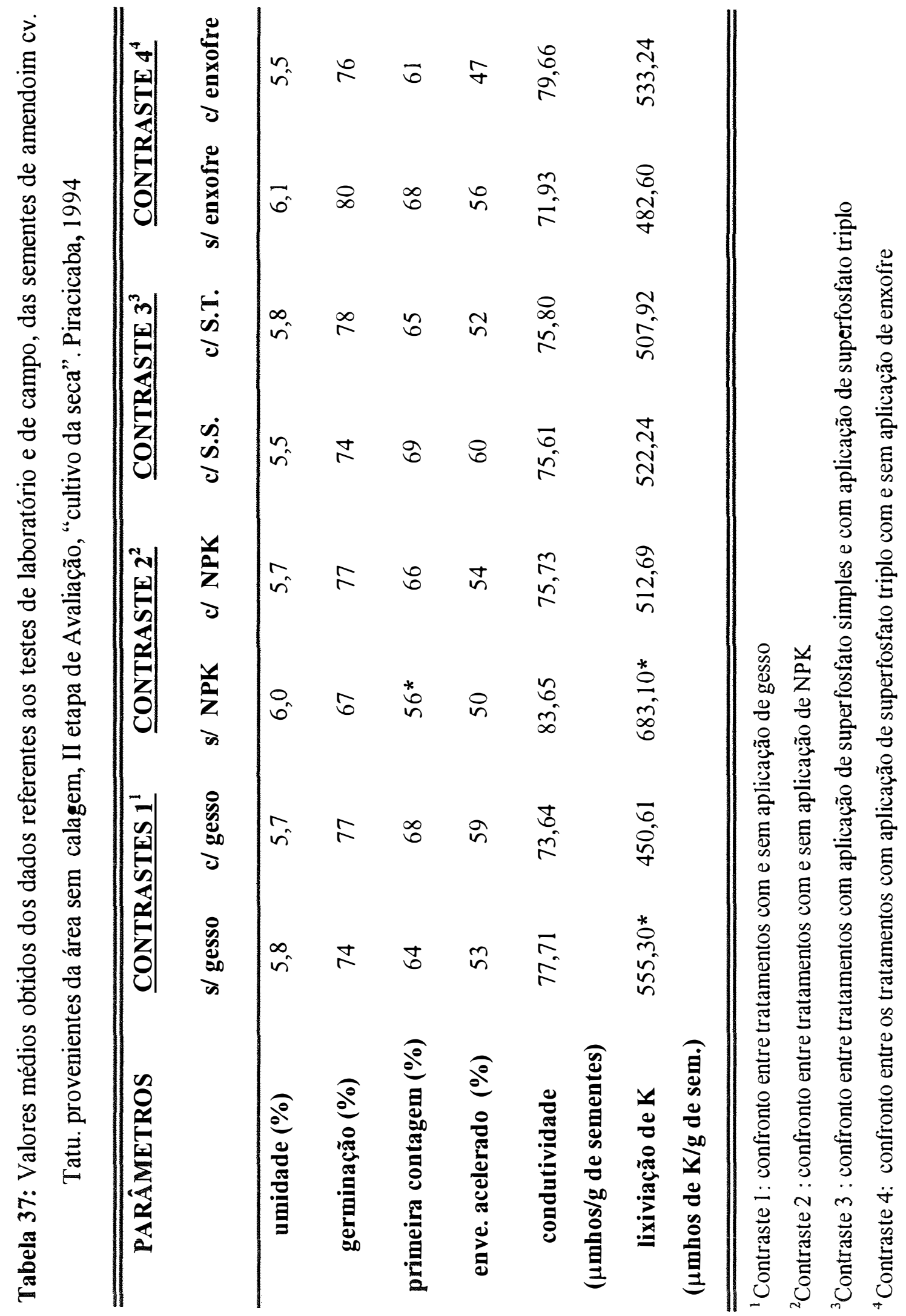




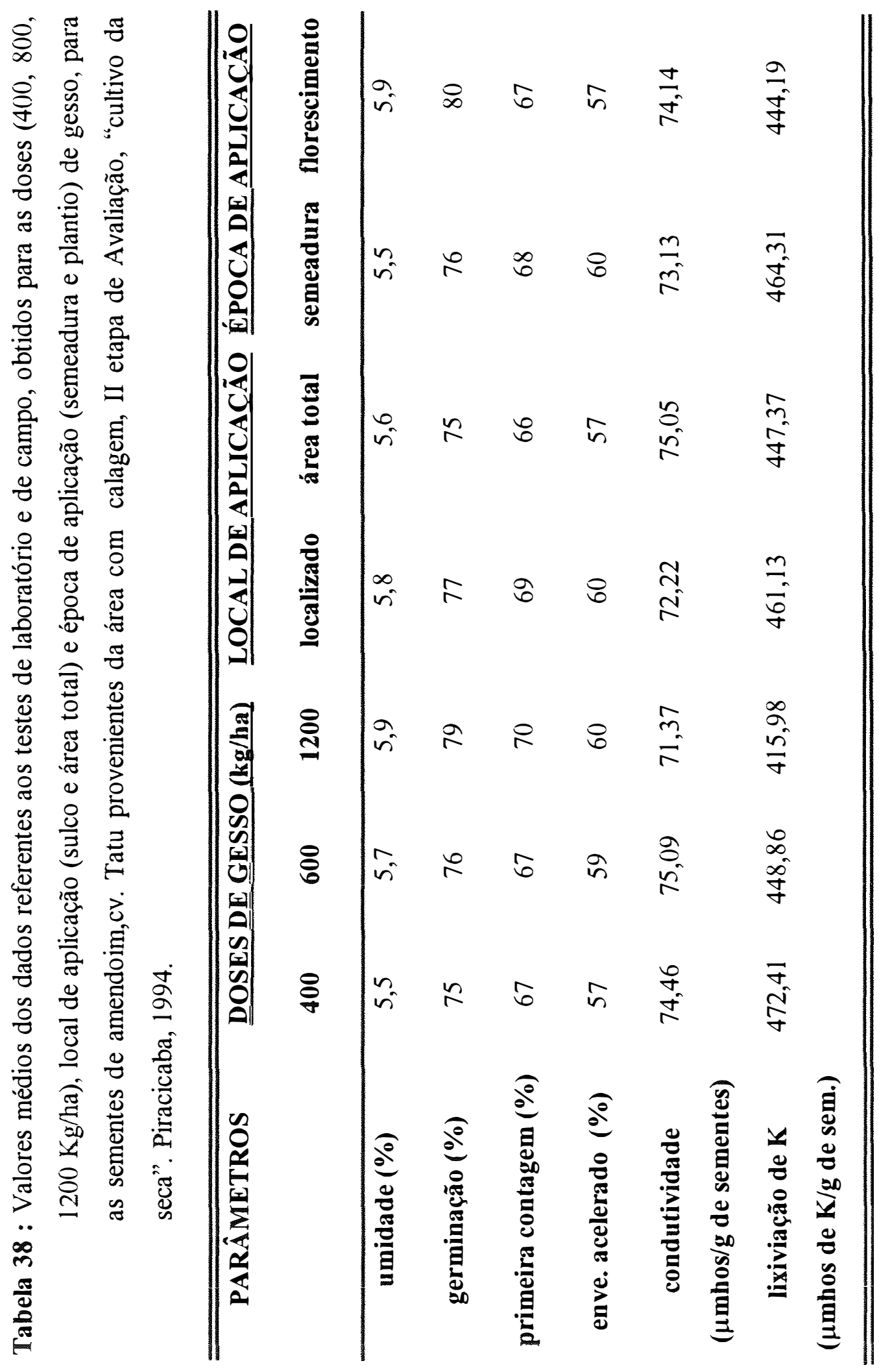




\subsubsection{Considerações Gerais II}

Neste experimento (área sem calagem),
observou-se que para o "cultivo das águas" na I Etapa de
Avaliação, houve interferência do gesso agrícola no peso de 100 sementes, germinação e vigor das sementes.

Para o peso das sementes esta interferência

foi negativa, isto é, as sementes que receberam gesso agrícola apresentaram peso inferior ao das sementes que não receberam. Para a germinação e vigor o efeito foi benéfico. Com relação aos outros fatores analisados, - fator local de aplicação do gesso agrícola, foi o único a revelar interferência na germinação, na qual a aplicação do gesso agrícola na área total foi mais satisfatória, tanto no cultivo das águas como no da seca. O vigor das sementes no cultivo das águas, pelos parâmetros primeira contagem e envelhecimento acelerado das sementes, também apresentaram - mesmo efeito do local de aplicação de gesso agrícola agrícola agrícola.

As sementes do "cultivo da seca" nesta área sem calagem, não apresentaram nenhum efeito da aplicação do gesso agrícola.

Na segunda etapa de avaliação para ambos os cultivos nenhum efeito do gesso agrícola foi observado.

A superioridade em termos de qualidade de sementes, assim como, a menor porcentagem dos teores de macronutientes encontrados no "cultivo da seca" em relaçào ao "cultivo das águas", pode ser justificado pelas mesmas causas climáticas referidas ao Experimento I lárea com calagem). 


\section{CONCLUSÕES}

Pela análise e interpretação dos resultados pode-se concluir que:

- No "cultivo das águas", em área sem calagem, o gesso agrícola é benéfico para a qualidade das sementes de amendoim, independente das doses, épocas e locais de aplicação.

- Em área com calagem, a aplicação de gesso agrícola é dispensável para a qualidade das sementes.

- O teor de cálcio nas sementes, não se relaciona com a qualidade das sementes de amendoim. 


\section{REFERÊNCIAS BIBLIOGRÁFICAS}

ADAMS, F.\& HARTZOG, D. The nature of yield response of Florunner peanuts to lime. Peanut science. Yoakum, 7: $120-3,1980$.

ADAMS, F.\& PEARSON, R. W. Differential response of cotton and peanuts to subsoil acidity. Agronomy Journal. Madison, $62(1): 9-12,1970$.

AMORIM,H.V. Aspectos bioquímicos e histoquímicos do grão de café verde relacionados com a determinação da qualidade. Piracicaba, 1978. 85p. (Livre-docência Escola Superior de Agricultura "Luiz de Queiroz"/USP) .

ASSOCIATION OF OFFICIAL SEED ANALYSTS. Seed vigor testing handbook. East Lansing, AOSA, 1983. 88p. (Contribution, 32 ).

BAtAgliA, O.C.; FURLANI, A.M.C.; TEIXEIRA, J.P.F.; FURLANI, P.R.; GALLO, J.R. Métodos de análise química de plantas. Campinas, Instituto Agronomico, 1983. 48p.

BELL, M.J. Calcium nutrition of peanuts (Arachis hypogaea L.) on cokatoo sands of the ord river irrigation are. Australian Journal of Experimental Agriculture. East Melbourne, 25(3):642-8, 1985. 
BELL, R.W.; EDWARDS, D.G.; ASHER, C.J. Effects of calcium supply on uptaks of calcium and selected mineral nutrients by tropical food legumes in solution culture. Australian Journal Agriculture Res., 40:1003-13, 1989.

BEWLEY, J.D.\& BLACK, A.M. Sedds - physiology of development and germination. New York, Plenum Press, 1985. 367p.

BRASIL. Ministério da Agricultura. Secretária Nacional de Defesa Agropecuária Regras para análise de sementes. Brasilia, 1992. $365 \mathrm{p}$.

CAIRES, E.F. Resposta Diferencial de gentipos de amendoim (Arachis hypogae L.) à calagem, Botucatu, 1990. 114p. (Mestrado - Faculdade de Ciências Agrárias/UNESP).

CHAHAL, R.S. \& VIRMANI, S.M. Uptake and translocation of nutrients in groundnut (Arachis hypogaea L.) .I Calcium. Oléagineux. Paris, 4: 181-4,1973.

CHAHAL, R.S. \& VIRMANI, S.M. Uptake and translocation of nutrients in groundnut (Arachis hypogaea L..). .IISulphur. Oléagineux, Paris, 29: 415-7,1974.

COELHO, F.A.S. \& TELLA, R. Absorção de nutrientes por plantas de amendoim na cultura de outono. Bragantia. Campinas, 26(18): 235-52, $1967 \mathrm{a}$.

COELHO, F.A.S. \& TELLA, R. Absorção de nutrientes por plantas de amendoim na cultura de outono. Bragantia, Campinas, 26(18): 393-408, $1967 \mathrm{~b}$. 
COFFELT, T.A. \& HALLOCK, D.L. Soil fertility responses of Virginia-type peanuts cultivars. Agronomy Journal, Madison, $78(1)$ : $131-7,1986$.

COX, F.R. \& REID, P.H. Calcium boron nutrition as related to concealed damage in peanuts. Agronomy Journal. Madison, 56(1):173-6, 1964 .

COX,F.R.; ADAMS,F.; TUCKER,B.B. Liming, fertilization and mineral nutrition. IN: PATTEE, H. E. \& YOUNG, C.T, ed. Peanut science and technology. Yoakum, American Peanut Research and Education Society, 1982. p.139-63.

COX, F.R.; SULLIVAN, G.A.; MARTIN, C.K. Effect of calcium and irrigation treatments on peanut yield, grade and seed quality. Peanut Science. Yoakum, 3: 81-5,1976.

DELOUCHE, J.C. Environmental effects on seed development and seed quality. Horticulturae science. St. Joseph, $15(6): 775-80$.

FERREIRA, M.E.; FORNASIERI, D.; VITTI, G.C.; MARVUlO, C. Estudo de doses e época de aplicação do gesso na cultura do amendoim (Arachis hypogaea L.). Científica, Jaboticabal, 7(2): 235-40, 1979 .

FORNASIERI, J. L. Viabilidade do uso do gesso e de calcário em amendoim (Arachis hypogaea L.). Jaboticabal, 1985. 75p. (Mestrado - Faculdade de Ciências Agrárias e Veterinárias/UNESP). 
FORNASIERI, J.L.; FERREIRA, M.E.; VITTI, G.C.; FORNASIERI FILHo, D. Efeitos do uso de calcário e de gesso sobre algumas características produtivas do amendoim (Arachis hypogaea L.) "das águas". Científica, São Paulo, $15(1 / 2): 45-54,1987$.

GEUS, J.C. Groundnuts or peanuts fertilizer for the tropics and subtropics (Arachis hypogaea I.), Zurichi, Center dÉtude de I'Azote, 1973.

GILLER, P. \& SILVESTRE, P. El Cacahuete o maní. Barcelona, 1970. $281 \mathrm{p}$.

GODOY, O.P.; MARCOS FILHO, J.; CÂMARA, G.M. de S. Tecnologia da produção In: CÂMARA, G.M. de S.; GODOY, O.P.; MARCOS FILHO, J.; FONSECA, H. Amendoim: produção, préprocessamento e transformação agroindustrial. São Paulo, Secretaria da Indústria, Comércio, Ciência e Tecnologia, s.d. 44p. (Série Extensão Agroindústrial, 4).

GUILHERME, M.R. Efeitos da aplicação de calcário calcinado, gesso e a mistura de calcário dolomítico calcinado e gesso em culturas de interesse econômico. Piracicaba, 1986. 56p. (Mestrado - Escola Superior de Agricultura "Luiz de Queiroz"/USP).

HALLOCK, D.L. \& ALLISON, A.H. Effect of three Ca sources aplied on peanuts. I. Productivity and seed quality. Peanut Science. Yoakum, 7:19-25,1980. 
HANGER, B.C. The movement of calcium in plants Communicattion in Soil Science and Plant Analysis, New York, $10(142): 177-93,1979$.

HARRIS,H.C. \& BROLMANN, J.B. Comparison of calcium and Boron deficiencies of the peanut. II seed quality in Relation to histology and viability. Agronomy Journal, Madison, 58(6): 578-82, 1966 .

LOEFFLER, T.M.; TEKRONY, D.M.; EGLI, D.B. The bulk conductivity test as an indicator of soybean seed quality. Journal of Seed Technology. Lansing, 12 (1): $37-53,1988$.

MAEDA, J.A.; LAGO, A.A. do; TELLA, R. de. Efeito de calagem e adubação com NPK na qualidade de sementes de amendoim. Pesquisa Agropecuária Brasileira. Brasilia, 21(9): $941-$ 4 , set. 1986 .

MALAVOLTA, E. Elementos de nutrição mineral de plantas. São Paulo, Agronômica Ceres, 1980. 251 p.

MARCOS FILHO, J.; AMORIM, H.V.;SILVAROLLA, M.B.; PESCARIN, H.M.C. Relações entre germinação, vigor e permeabilidade das menbranas celulares durante a maturação de sementes de soja. In:SEMINARIO NACIONAL DE PESQUISA DE SOJA, 2., Brasília, 1981. Anais. Londrina, EMBRAPA/CNPSO, 1982. p.676-88.

MARCOS FILHO, J.; PESCARIN, H.M.C.; KOMATSU, Y.H.; DEMÉtRIO, C.G.B.; FANCELLI, A.L. Teste para avaliação 
do vigor de sementes de soja e suas relações com a emergência das plântulas em campo. Pesquisa Agropecuária Brasileira. Brasília, 19(5):605-13, maio 1984.

MATTHEWS, S. Evaluation of techniques for germination and vigor studies seed Science. \& Technology, Zurich, 9(2). $543-51,1981$.

NAKAGAWA, J.; IMAIZUMI, J.; ROSSETO, C.A.V. Efeitos de algumas fontes de fósforo e da calagem na qualidade de sementes de amendoim. Pesquisa Agropecuária Brasileira. Brasilia, 25(4):505-12, abr. 1990.

PIVettA, A.R., Efeito de doses de gesso e épocas de aplicaçào na cultura do amendoim (Arachis hypogaea L.) CV, Tatu V.53. Jaboticabal, 1978. 44p. (Graduação Faculdade de Ciências Agrárias e Veterinaria de Jaboticabal/UNESP) .

QUAGGIO, J.A.; DECHEN, A.R.; RAIJ, B.van Efeitos da aplicação de calcário e gesso sobre a produção de amendoim e lixiviação de bases no solo. Revista Brasileira de Ciência do Solo. Campinas, 6(3): 189-94, 1982 .

RODRIGUES FILHO, F.S.O.; GODOY, I.J. de; FEITOSA, C.T. Acúmulo de matéria seca e nutrientes em plantas de amendoim cultivar Tatui-76. Revista Brasileira de Ciência do Solo, Campinas, 10(1): 61-6, 1986. 
Rosseto, C. A. V. Efeito do momento de colheita e da calagem na produção e qualidade de sementes de amendoim (Arachis hypogaea L.) CV. Botucatu. Botucatu, 1993. 114p. (Mestrado - Faculdade de Ciências Agrárias, UNESP ) •

SÁ, M.E. Importância da adubação na qualidade de sementes In: SIMPÓSIO SOBRE ADUBAÇÃO E QUALIDADE DOS PRODUTOS AGRÍCOLAS, 1.,Ilha Solteira, 1989. Ilha Solteira, UNESP, 1990. p.irreg.

SICHMANN, W. Estudos sobre os efeitos do fósforo e do cálcio em amendoim (Arachis hypogaea L.) cultivar Tatu, conduzidos em solução nutritiva e em solos arenosos, com relação à produção de vagens e algumas características dos frutos. Piracicaba, 1972. 112p. (Doutorado - Escola Superior de Agrigultura "Luiz de Queiroz"/USP).

SICHMANN, W.; NEPTUNE, A.M.L.; MELLO, F.A.F.de Efeito da aplicação de calcário e gesso na produção de vagens e sobre algumas características dos frutos de amendoim (Arachis hypogaea L.) em experimento conduzido em vasos contendo um podzolizado de Lins e Marilia. Anais da Escola Superior de Agricultura "Luiz de Queiroz", Piracicaba, 39: 337-47, 1982 .

SICHMANN, W.; NEPTUNE, A.M.L.; SABINO, N.P. Acumulação de macronutrientes pelo amendoim (Arachis hypogaea L.) cultivado em outono, época seca. Anais da Escola Superior de Agricultura "Luiz de Queiroz", 27: 393-409, 1970. 
SULLIVAN, G.A.; JONES, G.L.; MOORE, R.P. Effects of dolomitic limestone, gypsum and potassium on yield an $d$ seed quality of peanuts. Peanut science, Yoakum, 1: 737,1974 .

TELLA, R.; LAGO, A.A.do; ZINK, E. Efeitos de diversos níveis de umidade de sementes de amendoim. Bragantia, Campinas, 35: 335-42, 1976.

TOLEDO, F.F. \& J.MARCOS FILHO Manual de Sementes; Tecnologia da Produção.são Paulo, Agronômica Ceres, $1977.224 \mathrm{p}$.

VIEIRA, R.D.; FORNASIERI, D.; FORNASIERI, J.L.; DECARO, S.; FERRERA, M.E. Efeito da aplicação de calcário e gesso na qualidade de sementes de amendoim. Revista Brasileira de Sementes, Brasilia, 8(2):99-108,1986.

VITTI, G.C. Macronutrientes secundários; situação, perspectivas e sugestões. Piracicaba, Escola Superior de Agricultura "Luiz de Queiroz", 1986. 37p.

VITTI, G.C.; FERREIRA, M.E.; MALAVOLTA,E. O gesso agrícola como fonte de cálcio e enxofre - respostas de culturas anuais e perenes. In:SEMINÁRIO SOBRE O USO DO FOSFOGESSO NA AGRICULtURA, Brasília, 1985. Anais. Brasilia, EMBRAPA/DDT, 1986. p.17-43.

WALKER, M.E. Calcium requiremente for peanuts. Communication in Soil science and Plant Analysis. New York, 6(3):299-313, 1975. 
WALKER, M.E.; MULLINIX, B.G.; KEISLING, T.C. Calcium level in peanut fruting zone as influenced by gypsum particle size and aplication rate and time. Communication in Soil Science and Plant Analysis. New York, 12:427-39, 1979.

WIERSUM, L.R. Effects of environmental and cultural practices on calcium nutrition. Communicattion in soil Science and Plant Analysis, New York, 10 (1/2): 259-78, 1979. 
ANEXOS 


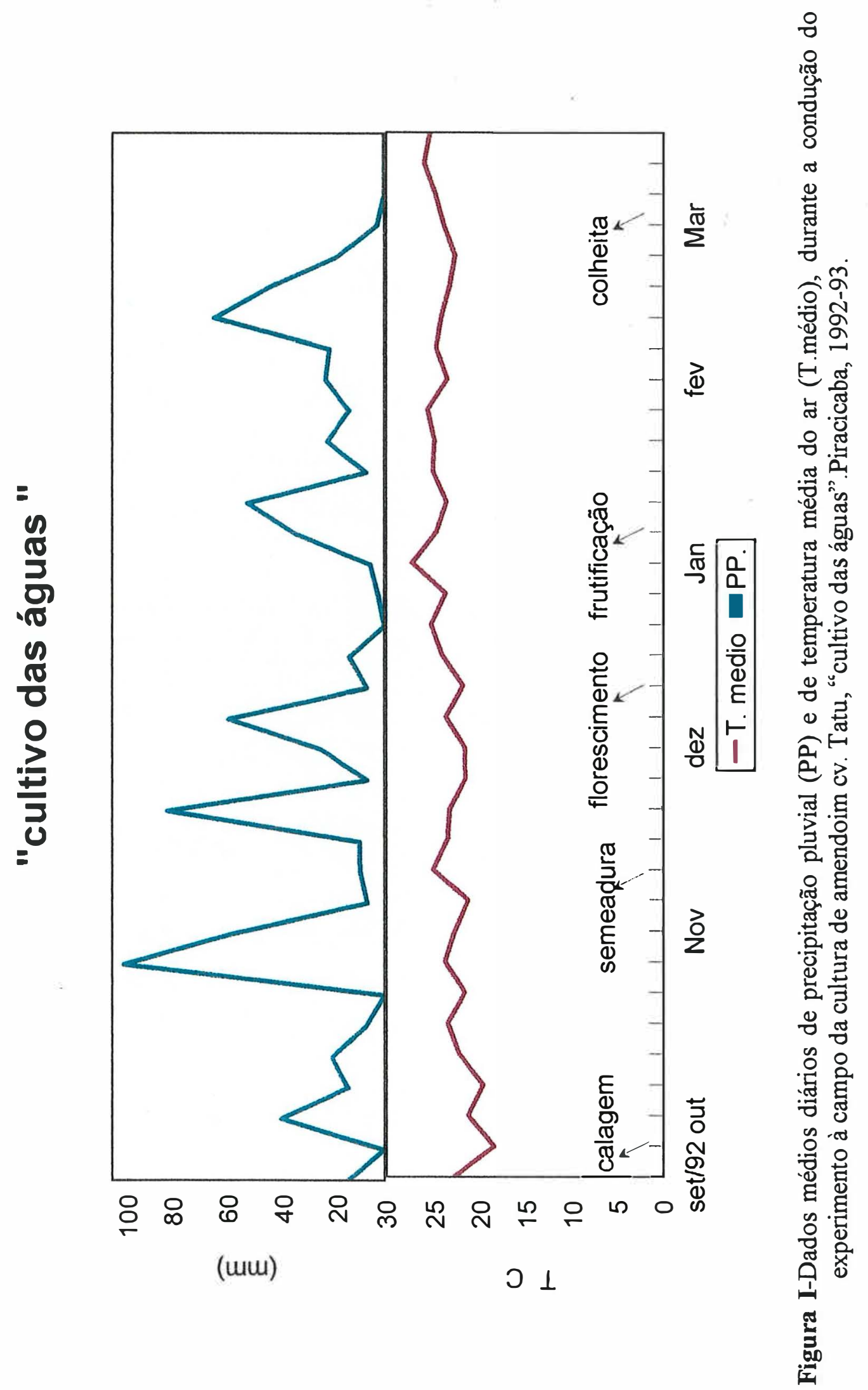




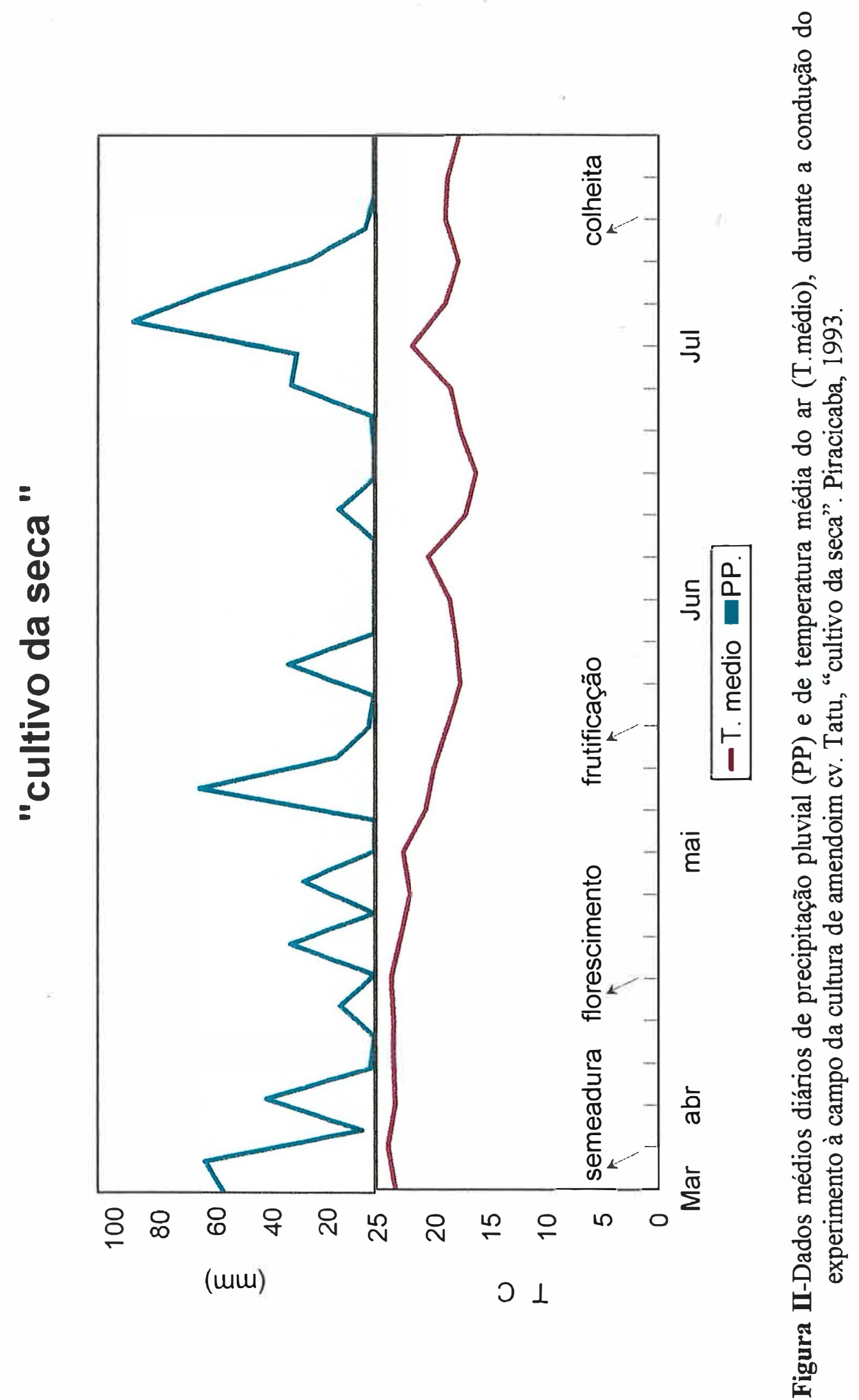




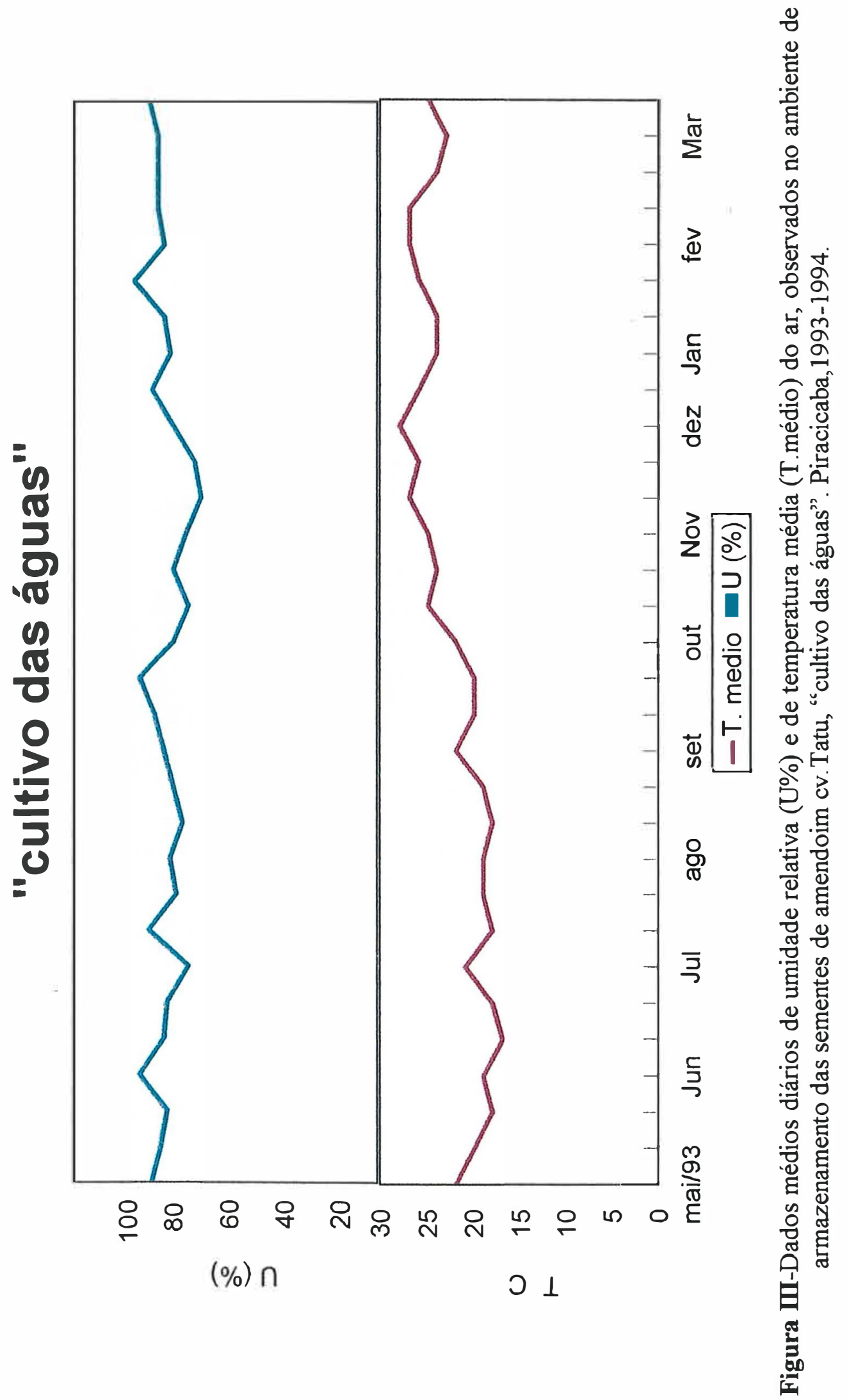




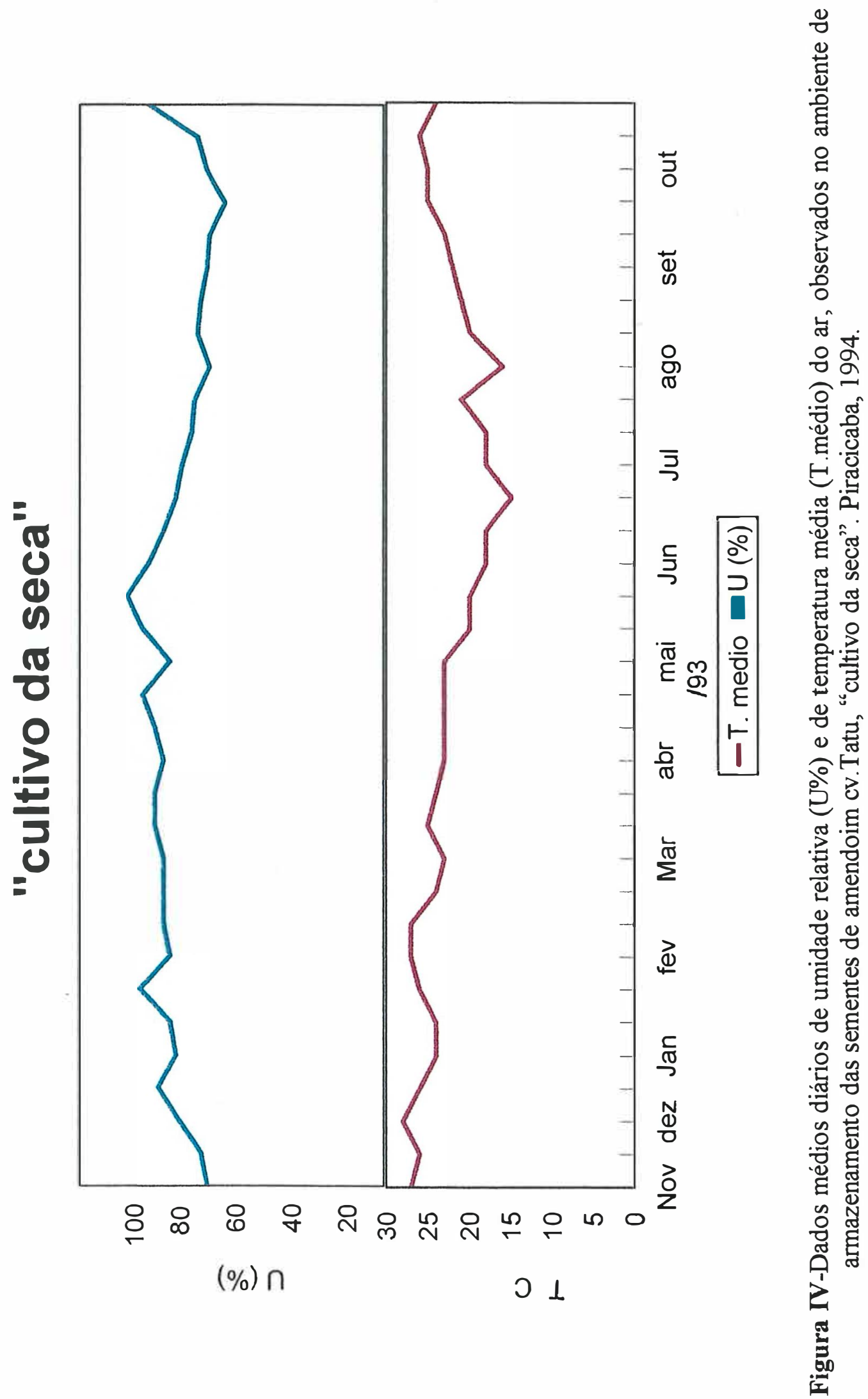

